Portland State University

PDXScholar

7-20-1993

\title{
Unadorned by Silence: Rereading Obedience in the Writing of Perpetua, Dhuoda, and Hildegard of Bingen
}

Rebecca Anne Walker

Portland State University

Follow this and additional works at: https://pdxscholar.library.pdx.edu/open_access_etds

Part of the History Commons

Let us know how access to this document benefits you.

Recommended Citation

Walker, Rebecca Anne, "Unadorned by Silence: Rereading Obedience in the Writing of Perpetua, Dhuoda, and Hildegard of Bingen" (1993). Dissertations and Theses. Paper 4642.

https://doi.org/10.15760/etd.6526

This Thesis is brought to you for free and open access. It has been accepted for inclusion in Dissertations and Theses by an authorized administrator of PDXScholar. Please contact us if we can make this document more accessible: pdxscholar@pdx.edu. 
AN ABSTRACT OF THE THESIS OF Rebecca Anne Walker for the Master of Arts in History presented July 20, 1993.

Title: Unadorned By Silence: Rereading Obedience in the Writing of Perpetua, Dhuoda, and Hildegard of Bingen.

APPROVED BY THE MEMBERS OF THE THESIS COMMITTEE:
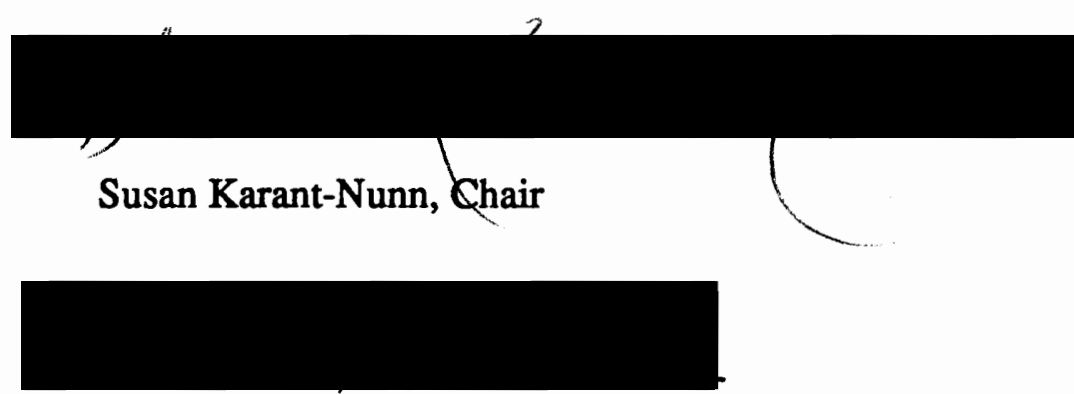

Michael Reardon
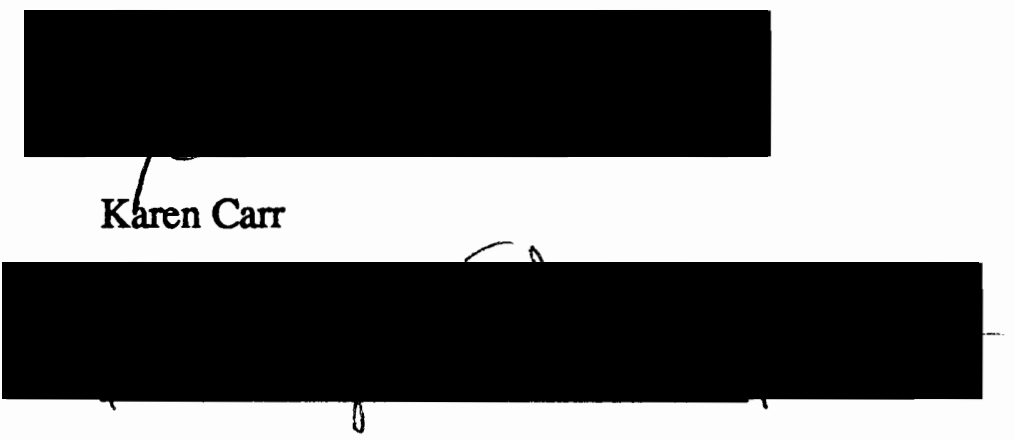

Gregory Goekjian

In her fourth letter to Abelard, Heloise asks the question, "Oh what will become of us obedient ones?" The question presents a paradox. By putting her question in writing, Heloise violates the code of silence imposed on medieval women. The medieval church 
and the literate aristocracy agreed with Sophocles and Aristotle: silence is the adornment of women. Gender roles in medieval society were unambiguous. Men, by nature, belonged in the public, political arena where they directed the affairs of the world, in part, by thinking, speaking, and writing. Obedient to male authority, a woman's natural place was in the private, domestic domain where she was expected to perform the duties of daughter, sister, wife, and mother in muted obscurity. In spite of these restrictions, a few women put pen to parchment during the Middle Ages.

This thesis examines the writing of three of these women, Perpetua, Dhuoda, and Hildegard of Bingen. Like Heloise, they considered themselves obedient even though they created texts in which they made their ideas and experiences available to readers in the male-dominated public discourse community. Research indicates that, because they were born into upperclass families, Perpetua, Dhuoda, and Hildegard probably enjoyed an education comparable to that of upperclass men. Although the curriculum available to each of these women included reading and writing Latin, researchers agree that writing was not considered an appropriate activity for medieval women. In addition to the cultural belief that good women were obedient and silent, it was also assumed that women were intellectually inferior to men and therefore not equipped to be competent writers. Research into theories about the process of thinking and writing has demonstrated that once such cultural assumptions are embedded in the human meaning-making system they are rarely questioned. These assumptions are perpetuated because the process of defining experience and developing ideas involves recombining patterns and metaphors provided by other writers and thinkers who usually share these beliefs.

Perpetua's, Dhuoda's, and Hildegard's texts indicate that they accepted these cultural assumptions about women and did not question the fact that patterns and metaphors created by female writers were not available to them. Nevertheless, it is evident throughout the writing of all three women that they possessed genius and skill equal to that 
of men with similar intellectual gifts and educational opportunities. Yet the texts written by these women are often dismissed as less significant than texts written by men. Further research in rhetorical theory led to the realization that Perpetua, Dhuoda, and Hildegard have often been considered inferior writers, not because they were, but because the reader knows that he or she is reading a text written by a woman.

Readers of these texts traditionally have assumed that these authors were obedient because they accepted their subservient position to men and the belief that women were, by nature, less intelligent and capable than men. This has led to the assumption that if the author acknowledges her inferiority she must indeed be a less competent artist than her male counterparts. Such readings have resulted in assessments of theses texts that ignore the complexity, art and significance of the work. This thesis demonstrates that the reader willing to suspend these assumptions in the process of reading Perpetua, Dhuoda, and Hildegard may find writing that is anything but the work of obedient, submissive women. He or she may also find authors whose thinking and writing skills equal those of male writers and whose opinions, observations, and experiences are more than marginal glosses on their historical context. 


\title{
UNADORNED BY SILENCE: \\ REREADING OBEDIENCE IN THE WRITING OF PERPETUA, DHUODA, AND HILDEGARD OF BINGEN
}

\author{
by \\ REBECCA ANNE WALKER
}

A thesis submitted in partial fulfillment of the requirements for the degree of

\author{
MASTER OF ARTS \\ in \\ HISTORY
}

Portland State University

(C)1993 


\section{TO THE OFFICE OF GRADUATE STUDIES:}

The members of the Committee approved the thesis of Rebecca Anne Walker presented July 20, 1993.
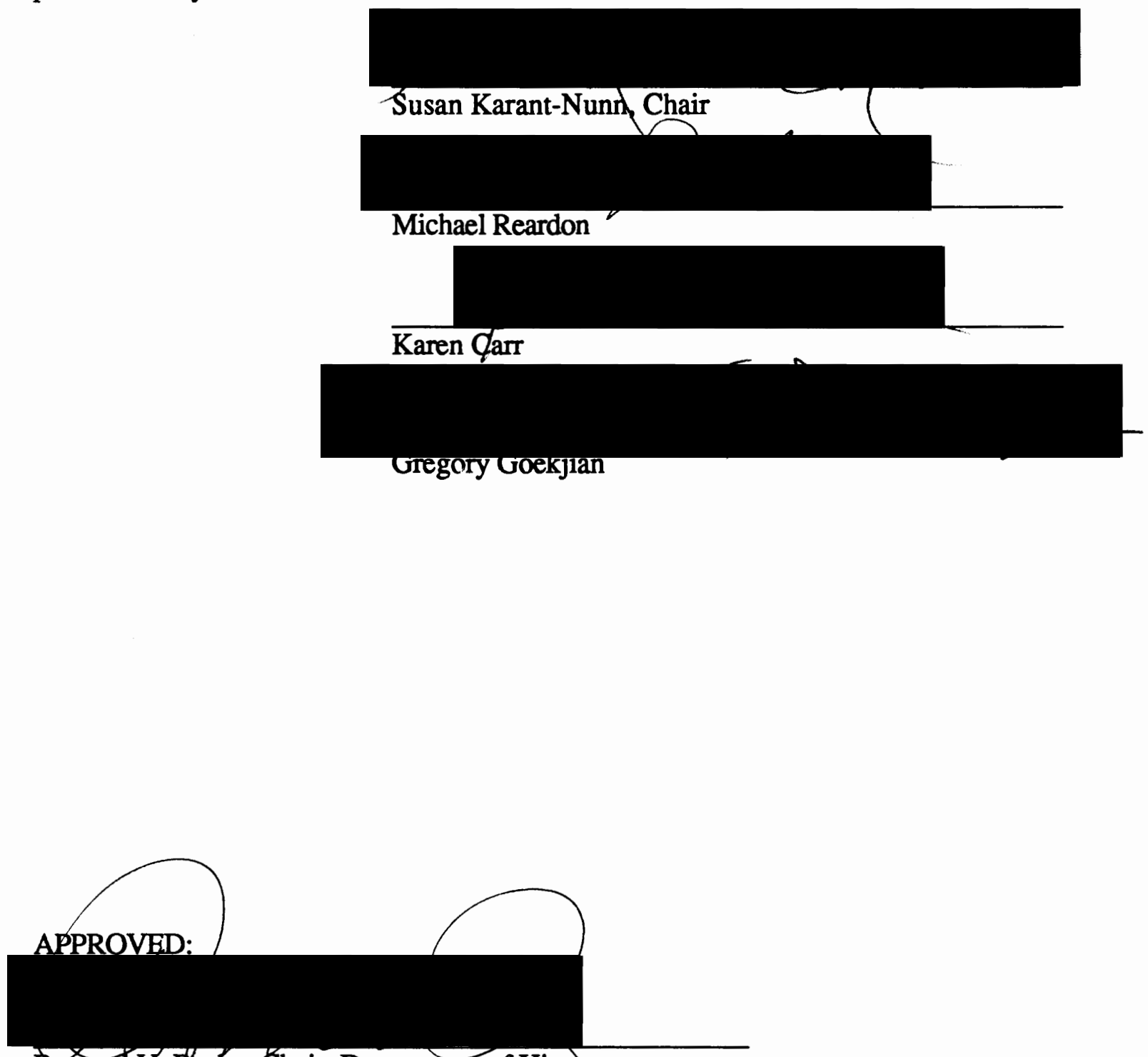

BernardV. Burke, Chair, Department of History

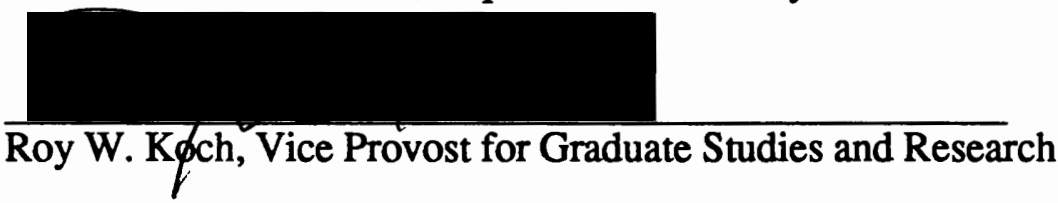




\section{ACKNOWLEDGEMENTS}

I borrow from my own patriarchal intellectual heritage when I ask Cicero to help me express my gratitude to those who have helped me arrive at this point in my academic career. All that I have learned and all that I have achieved during my years as an undergraduate and a Master's Degree candidate at Portland State University, I owe to my teachers.

Professor Georgia R. Crampton retired at the end of the 1989-90 school year leaving behind a legacy of students, like me, grateful for her scholarship, generosity, and infectious enthusiasm. Since her retirement, she has continued to provide guidance and encouragement as I worked on this project. Professor Susan Karant-Nunn, my advisor in history, has been an unfailing source of necessary criticism and much needed support, as well as a model of ethical, well-bred scholarship. Professor Karant-Nunn and Professor Paul Giles, the English Department's Graduate Advisor, worked together to guide me through the intricacies of meeting the requirements for a dual Master's Degree in History and English. To Professor Christine Rose, my thesis advisor in English, I owe a special thanks. Her criticisms posed difficult challenges that have strengthened and improved the argument. I appreciate the comments and encouragement of Professor Michael Reardon, Professor Karen Carr, and Professor Gregory Goekjian, members of my History committee. I also thank Professors Peter Carafiol and Tony Wolk who examined me in English. Professors Deeanne Westbrook and Duncan Carter, along with Gregory Goekjian (even though he was on sabbatical during part of the time I was working on my thesis), were more than generous with their helpful feedback and support and I am deeply grateful. I am especially grateful to Katya Amato for her help with the difficult process of beginning 
the writing phase of this thesis. All of these people have taught me to read carefully and closely, to question and to imagine, and at all times to respect ( and criticize) my sources.

To introduce a Literary Criticism class discussion on Roland Barthes, Professor Goekjian asked the question, "Who writes your papers?" As I researched and began writing this thesis and realized the value of the responsel received from the scholars mentioned above, the relevance of this question took on new meaning for me. Therefore, in addition to thanking my generous teachers for their help, I would also like to thank the following colleagues who have been available to explore ideas and possibilities with me, counsel and support me, and just be good friends. Robie Webb has spent hours discussing, speculating, suggesting, criticizing, and editing as I worked through the challenges and complexities of composing this thesis. Rita and Jim Delater contributed ideas and thoughtful challenges long-distance from Seattle. Patty Ayala has provided a constant stream of encouragement, questions, and ideas, and Harvey Conover has always been willing to help me comprehend the subtleties of literary theory. I know I have omitted many who have contributed in one way or another to easing what Dhuoda calls the agonizatio of writing. Among those who must also be mentioned, however, are Lee Ellington, the History Department Graduate Secretary; Diane Gould, the History Department Coordinator; and Debby Halliburton, the English Department Coordinator. 
TABLE OF CONTENTS

PAGE

ACKNOWLEDGEMENTS .................. iii PREFACE .................... . . . .

CHAPTER

I INTRODUCTION . ...............

ENDNOTES ....................... 18

II DIALOGUE IN THE FACE OF DEATH

PERPETUA: CHRISTIAN MARTYRDOM IN GREEK

TRAGEDY METAPHORS . . . . . . . . . . . . . . 21

ENDNOTES ....................... 54

III DIALOGUE IN SELF-DEFENSE

DHUODA: A MILITANT MOTHER WITH A

SUBVERSIVE AGENDA . . . . . . . . . . . . 58

ENDNOTES ...................... 82

IV DIVINE DIALOGUES IN A DECADENT CENTURY

HILDEGARD OF BINGEN: A FEMALE PROPHET FOR AN

"WOMANISH TIME" . . . . . . . . . . . . . . 86

ENDNOTES ....................... 111

V CONCLUSION .................... 115

ENDNOTES ....................... 125

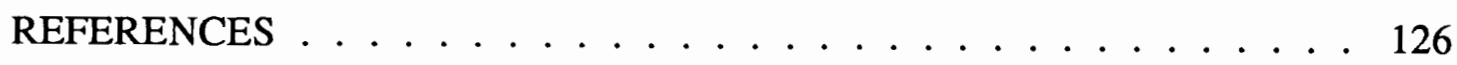




\section{PREFACE}

In Georgia R. Crampton's “Medieval Lives" class, spring term 1990, I was introduced to texts attributed to medieval women authors including the work of the three women discussed in this thesis: Vibia Perpetua, a third-century Christian martyr; Dhuoda, a ninth-century Carolingian noblewoman and mother, and Hildegard of Bingen, a twelfthcentury German visionary, abbess, and theologian. Reading assignments for Professor Campton's class also included Heloise's letters to Abelard. In her fourth letter, Heloise asks, "Oh, what will become of us obedient ones?" Her question haunted me.

When I began my master's program during summer term 1991, I decided look for an answer to Heloise's question. I began my research by reading the texts of four ostensibly obedient medieval women: the three mentioned above and Heloise. The research question at that time was: What happened to these women as a result of their writing? Almost immediately, I realized that this question had to be accompanied by a second question. Given the fact that all these women were products of and immersed in vigorously stratified patriarchal cultures in which women were considered intellectually as well as physically inferior to men, what enabled and motivated these women to write?

As my research progressed, I found myself troubled by aspects of each woman's writing. I am still uncomfortable with Perpetua's description of her cavalier treatment of her father and casual dismissal of her infant son. Reading Dhuoda and Heloise as banished and abandoned by callous husbands, I was as irritated with them for spinelessly accepting their roles as victims as I was angered by the fact that this treatment of women was permitted and condoned. Hildegard posed two problems. Unlike the others, she resisted the role of a meekly subservient woman. She claimed that her writing is authored by God 
and, by implication, that she did not write her text but only described what she had seen and heard. I am still bothered by the brilliant, assertive woman who shines through her divinely inspired prose and poetry but refuses to claim even partial ownership.

In their texts, each of these women describes herself as obedient, faithful, and loyal to both religious and secular authority. However, as I reread them, I realized that, in the very act of writing, these women were violating cultural norms for women's behavior. As I read more closely, it became apparent that what each of these women was saying also challenged secular and theological definitions of women. In spite of this fact, these text were read, copied, and preserved as the work of exemplary women. The very existence of the texts stimulates another question: how is it that these women were not only allowed to write but also to be admitted into the public discourse arena?

In order to begin to answer this question, I needed to learn more about each woman's historical context. I needed to know more about the roles and expectation of women in third-century Carthage and ninth- and twelfth-century Europe. Especially important to this phase of my research was learning about women's opportunities for education and options, if any, for participating in the male-dominated arena of public discourse. By comparing each writer's experience and thought, as revealed in her text, to the cultural norms of her historical context, I attempted to determine to what degree each of these women conformed to or went against church doctrine and secular practice.

As I began to research recent scholarship on the work of Perpetua, Dhuoda, Hildegard, and Heloise, it became apparent that not only were these women read as obedient by their contemporaries, but they were still being read, as I read them initially--as obedient women subservient to patriarchal expectations. Only in the writing of Hildegard, thanks to close readings by feminist researchers, have scholars begun to detect subversive content . 
The realization that twentieth-century scholars were overlooking the things I was seeing in these texts raised other questions: How and why do contemporary readers of these women's texts preserve the interpretation of them as obedient, subservient authors, and what effect does this reading have on the assessment of the value of these texts as literature and as a source of historical information? As I tried to answer these questions, I discovered that each author to varying degrees carefully and skillfully reinforces her obedience, aware of the fact that appearing to acquiesce to patriarchal expectations is essential to being invited into the public discourse community. At this point, two other problems presented themselves. In the intellectual context available to each woman, the contemporary and antecedent thinkers and writers were men. Therefore, I began to examine the extent to which the language each author uses to express her thoughts and experience conforms to her intellectual heritage and, at the same time, is molded against it.

Typically, as I tried to answer each question, more questions presented themselves. As I read Dhuoda's text, her version of the political intrigue following the death of Louis the Pious challenged my assumptions about history. Dhuoda's powerful rhetoric forced me to consider the idea that history itself is a constructed narrative; of necessity, even chroniclers select, prioritize, eliminate, and interpret information based on criteria determined by the prevailing agenda. My examination of the work of contemporary scholars looking at Perpetua's, Dhuoda's, Hildegard's, and Heloise's texts also sent me in search of theories about reading and writing. In order to understand why these women were still being read as obedient, I had to investigate current theories about how readers interpret what they read.

As a result, by January 1993, I was forced to eliminate Heloise, ironically the woman whose question initiated this project, from consideration. I based my decision on the simple fact that, at that time, I had done more work on Hildegard than on Heloise. In the end, the answers to most of the questions I posed are far more complicated than I had 
anticipated and only remotely approximate the answers I expected. More importantly, these answers do not provide the one and only true reading of Perpetua, Dhuoda, and Hildegard's texts. They constitute, instead, the suggestion that a reading exists that counters the prevailing interpretation of these texts as the work of orthodox, obedient women. Such a reading also refuses to allow the assumption that their acceptance of their marginalized position in intensely patriarchal societies justifies labeling them as inferior writers and historically less important that their male contemporaries. 


\section{CHAPTER I}

\section{INTRODUCTION}

From the house I have come forth, Corinthian ladies, for fear lest you be blaming me: for well I know that amongst men many by showing pride have gotten them an ill name and a reputation for indifference, both those who shun men's gaze and those who move amid the stranger crowd, and likewise they who choose a quiet walk in life. For there is no just discernment in the eyes of men. Euripides, Medea $212-220$

When Medea "comes forth from the house" in the opening scene of Euripides's play, she steps into history and literature as an icon of the malevolent female outlaw. Medea follows the statement above by declaring her intention to take revenge against Jason for his betrayal of her. The actor playing Medea moves on stage to say these lines ${ }^{1}$ and, in so doing, symbolizes Medea's move from the private, domestic domain where women belong, unseen and silent, into the public, political realm where men's thoughts and actions, create literature and write history. As a barbarian princess and a sorceress, Medea is powerful as well as disobedient. In Euripides's portrayal of her, Medea embodies the treacherous potential of a strong intelligent woman who refuses to accept her place as inferior and subservient to men.

The biblical Eve, who lacks Medea's power as a sorceress and princess, enters history and literature as the icon of female disobedience in the Judeo-Christian tradition. According to Genesis 3, Eve's first act defies authority and is committed in the absence of Adam. Although it is not clear whether Eve learned about the Tree of Knowledge directly from God or from Adam, it is clear that her decision, based on her own logic, has far more disastrous effects on mankind than Medea's acts of vengeance. But Eve is neither powerful nor intelligent. She is vulnerable to the Devil's deceit because either she is not 
bright enough to recognize it or she lacks the fortitude to resist his argument. As centuries of theologians have explained to believers, Eve commits the first sin because she is weak and gullible. Both Eve and Medea serve as a literary and historical warning to the generations of men and women who have grown up with one or both of these narratives as part of their heritage; women, whether they are powerful and intelligent or weak and gullible, are dangerous when they refuse to submit to the authority of men, and the human race is in grave danger when men fail to assert their authority.

Although it is difficult to determine at what point in the development of human thought the assumptions that warrant these conclusions about women and men surfaced, the fact is, they are so deeply rooted in most human cultures that for millennia men and women in Western civilization have accepted them as irrevocable laws of nature. In The Creation of Feminist Consciousness, Gerda Lerner explains how these assumptions have affected human behavior and thinking:

In the course of the establishment of patriarchy and constantly reinforced as the result of it, the major idea systems which explain and order Western civilization incorporated a set of unstated assumptions about gender, which powerfully affected the development of history and of human thought. ${ }^{2}$

Included in these assumptions, according to Lerner, are the concepts that "the male [is] the norm and the female [is] deviant; the male [is] whole and powerful; the female [is] unfinished, physically mutilated and emotionally dependent." These concepts support both the assumptions about differences in "needs, capacities, and functions" and the reading of men as "stronger and more rational, therefore designed to be dominant." Women, are “"naturally' weaker, inferior in intellect and ... unstable emotionally" and, while it is acknowledged that the functions of women are necessary, male responsibilities are more important. $^{3}$

Nevertheless, women have come forth from the house to participate publicly in the discourse of literature and history, although cautiously, aware that their male colleagues 
will accept obedient Eves but not evil Medeas. Three such women, Perpetua, Dhuoda, and Hildegard, break the silence imposed on women. Each of these women writes about her experiences and expresses her ideas for an audience that includes male readers. As women writers, they face other problems unique to women authors. These problems stem from the fact that public discourse, based on the assumption that women are naturally inferior and subservient to men, places women in a relationship to authority different from that of men while, at the same time, their position requires them to use tools and methods of communication in which are embedded the assumptions that marginalize them. Because reading is also part of the patriarchal discourse system, readers, both male and female, read women as inferior writers regardless of how skillfully they manipulate the rhetoric. This situation means that when a woman uses language publicly, as a writer or a reader, she is working within a discourse system created to enforce her marginalization. According to Cheris Kramer, Barrie Thorne, and Nancy Henley, in their article "Perspective on Language and Communication":

In general men have been in control of determining what is labeled, have defined the ordering and classifying systems, have created the words which are catalogued in our dictionaries and which are the medium of everyday speech, and have placed prohibitions against women as public speakers. ${ }^{4}$

In order to write, women such as Perpetua, Dhuoda, and Hildegard had to recognize the potential exemplified by Medea and Eve.of being read as disobedient and therefore dangerous; consequently they carefully create texts that deflect such interpretations. Their texts demonstrate their understanding of the fact that the very act of writing, in addition to the content of their texts, flies in the face of the patriarchal cultural assumptions. Therefore, being read as obedient is essential to being read at all. Ironically, by appearing to be obedient, they tacitly accept the assumption that they are inferior. Readers logically assume that, if the writer admits her inferiority, she must indeed be inferior. This reading, in turn, justifies the polite dismissal of texts written by these and 
other women as the work of authors less competent than their male colleagues. The assumption that the writer lacks the ability of her male colleagues leads to a reading that treats the text as a curiosity and precludes any consideraton of skill or complexity.

The reader willing to suspend assumptions about about female obedience and inferiority discovers in the texts written by Perpetua, Dhuoda, and Hildegard writing that is anything but the work of obedient artless writers whose ability is inferior to that of their male counterparts and whose opinions, observations, and experiences belong, at best, inside the margins of history. By looking for writing by skilled authors also astute enough to realize that being accepted by their male authorities is a prerequisite to being read at all, a reading emerges that reveals authors whose texts are not only literature worthy of serious consideration but also sources of valuable insights into the ambiguous historical contexts of the works.

Theories about discourse systems--how they work and how the assumptions subsumed in them affect writing and reading--indicate that the marginalizing mechanisms embedded in a language operate at the involuntary level of meaning-making. Nicolae Babuts, in The Dynamics of the Metaphoric Field, explains how language and experience work together when an individual identifies and interprets information. This process operates similarly whether the individual is reading or writing. Babuts's theories are based on his study of work done in phenomenology, psycholinguistics, and neuroscience. According to Babuts, when an individual is confronted with the need to identify and interpret information, evidence indicates that a sequence of mnemonic processes are involuntarily set in motion. This process creates what he calls "metaphoric fields." As the experience or information being identified and interpreted is perceived, "dynamic patterns" stored in the memory by previous, similar processes are brought into the metaphoric field in such a way that they create new meaning or information based on analogies to existing patterns in the memory: 
The [metaphoric] field is a mnemonic space newly awakened by the involuntary strategy of memory, where single and fragmentary word-bonded dynamic patterns are brought into a proximity and conditioned to interact and produce new metaphoric sequences. ${ }^{5}$

While this process may be inherent in the function of the brain, it nevertheless depends on the "dynamic patterns" available in the memory. Babuts does not discuss the influence of gender on the creation of dynamic patterns. It is highly likely, however, that they are, in some way, gender based: on the one hand, by the gender of the thinker and, on the other hand, by the dominant gender of the culture and language available to the thinker. That is, because most language is masculine and because dynamic patterns are word-bonded, uniquely feminine dynamic patterns are available only if they are fused with the generic dominant masculine language. As a result, uniquely female meaning is virtually impossible except as a variation of male meaning:

In each case the process is set in motion by a detail from the present perceptual field or from the poem, a dynamic pattern, a bold metaphor, which attracts its corresponding, mnemonic sequence and alerts others in the background preparing them to contribute to the creation of the new field. ${ }^{6}$

The female thinker, writer, and reader must, consciously or unconsciously, bring what is available among her dynamic patterns into unconventional relationships in order even to begin to question the assumptions that support the patriarchal construction of meaning. Many literary and rhetorical theorists have observed this process in reading and composition, and several have proposed that language and experience work together at some fundamental stage in both reading and writing. These theories are usually based on observations of human behavior in the meaning making process. In The Dialogic Imagination, Mikhail Bakhtin explains how this process is manifest in the way medieval writers appropriate the language and ideas of their predecessors. For Bakhtin, this is a model of the dialogue that inevitably occurs between the writer, his or her text, and other texts: 
The relationship to another's word was ... complex and ambiguous in the Middle Ages .... The boundary lines between someone else's speech and one's own speech were flexible, ambiguous, often deliberately distorted and confused ....

The primary instance of appropriating another's discourse and language was the use made of the authoritative and sanctified word of the Bible, the Gospel, the Apostles, the fathers and doctors of the church. ${ }^{7}$

In this sense, all of these writers carry on what Bakhtin calls a dialogue with the writers who preceded them as well as a dialogue in their own historical context. Some of these dialogues are explicit, but the boundaries between speakers are often unacknowledged or blurred. Perpetua, Dhuoda, and Hildegard are typical medieval writers creating their manuscripts by pulling together passages, metaphors, and models from other writers into a pastiche of allusions that simultaneously retain their original meaning and combine to make new meaning. Perpetua's intellectual background is primarly classical. Therefore, she integrates her predecessors more subtly than the completely medieval Dhouda and Hildegard. As Michael Holquist explains in the glossary he provides for his edition of The Dialogic Imagination,

Everything means, is understood, as part of a greater whole ... here is a constant interaction between meanings, all of which have the potential of conditioning others. This dialogic imperative, mandated by the pre-existence of the language world relative to any of its current inhabitants, insures that there can be no actual monologue. ${ }^{8}$

The point to remember is that the language world that contributes to and conditions writing by women is male-dominated and based on assumptions that marginalize women. It is important, therefore, when reading Perpetua, Dhuoda, and Hildegard, to look at how they work within the language system available to them in ways that counter or work around marginalizing assumptions. However, because these assumptions are embedded not only in the language but also in the meaning-making system itself, making meaning in ways that overide these assumptions is a particular challenge for the woman writer or reader.

The process described by Babuts also resonates with theories regarding the interaction between texts, contexts, writers and readers put forth by Northrop Frye. In his 
essay "The Stage Is All the World," Frye introduces his topic by describing the individual's use of experience in the meaning-making process: "We are continually thrown back on our own repertoire of ideas and suitable responses."9 Although Frye was probably unaware of Babuts's theories, he explains, in his book Creation and Recreation, this apparent backward movement in the apparent process of moving forward, when he discusses the relationship between an individual's vision of the future and its relationship with the past: "We do not know the future at all except by analogy with the past, ... all vision of a social future must be rooted in the past, socially conditioned and historically placed."10

This dialogue between the past and the present, as well as between different aspects of the present, according to historiographer Lloyd S. Kramer, in his essay "Literary Criticism and Historic Imagination: The Historical Challenge of Hayden White and Dominique LaCapra," is active in the development of history as well as the creation of literature. In his essay Kramer, quotes Dominick LaCapra, illustrating his application of Bakhtin's concept of dialogization to the ambiguous reading and writing of history:

Bakhtin's emphasis upon dialogization directed attention to the more ambivalent or undecidable dimensions of texts ... and highlighted the importance of the border or the threshold where seeming opposites entered into an exchange and possibly coexisted, often intensely charged relationships." 11

LaCapra himself explains this possibility in Rethinking Intellectual History, when he argues against the "strictly documentary approach in historiography."12 The process of dialogization, he says, means a text can be discussed "in relation to any text in a manner that both opens it to an investigation of its functioning as discourse and opens the reader to the need for interpretation in his or her dialogue with it."13 Explicit here is the idea that the process of "documenting" history is essentially an ongoing dialogue not only between the historian and the text but also between the antecedents and context of the document.

Hayden White in Topics of Discourse recommends a similar approach to the reading of a text as history. Basing his theories on Julia Kristeva's concept of 
intertextuality, he discusses the ways in which this approach to a text as a source of historically valuable information problemized the assumed objectivity of historical reporting:

Properly understood, histories ought never to be read as unambiguous signs of the events they report, but rather as symbolic structures, extended metaphors, that "liken" the events reported in them to some form with which we have already become familiar in our literary culture. ${ }^{14}$

Applying Babuts's theories of meaning-making to White's concept of the creation of history results in a history that is inevitably selective and, therefore, incomplete from the point of view of the reader who does not share the writer's criteria for selection. This theory suggests that, in the process of creating history, historians need to look at available information with an awareness of the effects of patriarchal assumptions on the meaningmaking process. Through this process a historian can postpone his or her interpretation of a text as the heroic effort of a less than competent writer or the naive efforts of an oppressed victim until after the historian has attempted to assess the value of a text in terms of its historical significance.

These theories imply two important considerations affecting the reading of texts written by women in general and, specifically, the reading of texts considered in this thesis: one, that these women could not be expected to question openly assumptions so deeply embedded in their meaning-making processes that they could not have been aware of them without predecessors who initiated the questioning process and provided some metaphors on which to build new meaning, and two, that what these women did with language in terms of providing metaphors for those who came after them must be considered as significant contributions to literature and history.

Peter Dronke, in Women Writers of the Middle Ages: A Critical Study of Texts from Perpetua (203) to Marguerite Poiret (1310), originally published in 1984, states that in doing his research he realized that an "imposing mass of relevant material" by and about 
women writers remains relatively untouched by scholars. He admits to having to "adopt stringent principles of selection" in the process of choosing the fifteen or so women writers he includes in his book.15. The three women discussed in this thesis are among the women included in Dronke's book and were chosen, in part, because, according to Dronke, each woman wrote all, or part, of her text. In the process, each writer contributed a piece to the development of new literary genres and valuable information to history. Admittedly, other medieval women writers (for example, Heloise instead of Hildegard) would be acceptable using this criterion. However, the three women chosen for this study do present a variety of texts and agendas. Each writer is also working in a different historical context and responding to very different situations.

Perpetua, a third-century Christian martyr, wrote an account of her experience while in prison and, according to her redactor, gave strict instructions about the fidelity with which the framing material was to be presented. Dhuoda, a ninth-century Carolingian noblewoman, wrote a manual for her son in which she gives him instructions on how to conduct himself in a hostile court as a Christian, a nobleman, and a dutiful son. Hildegard, a twelfth-century Benedictine abbess and the most well-known of the three, wrote and illuminated a trilogy of books describing and interpreting her visions. She also composed sacred music, wrote the first mystery play and several secular works, and corresponded with powerful secular and religious figures throughout twelfth-century Europe.

As writers, each of these women, unlike her male colleagues, had to acquiesce in some way to male authority. Their male counterparts, on the other hand, wrote from an authority assumed by virtue of their position in the social hierarchy, which they could enhance with the addition of personal attributes such as education, rhetorical skill, and experience. To be taken seriously as writers, these women had to be invited, figuratively, into the discourse community by male authorities. This has been the case, not only in their own times, but in each generation they have been read. Part of this process involves 
avoiding any indication that the writer's agenda is unorthodox or dangerous. As Lerner explains this problem,

This was a task far different from that facing the male thinker, whose authority was unquestioned, whose right to his own experience was taken as a given and who could develop his thought standing in discourse with the great thinkers before him. ${ }^{16}$

Also essential to the successful woman writer was skill in the use of the language adequate to produce a credible text by the male dominant public standards. All of these women write in Latin, a language undeniably "determined, labeled, and defined"17 by masculine criteria and designated as the language of religion and scholarship. Once they establish their authority, however, Perpetua, Dhuoda, and Hildegard assume the male prerogative of naming and defining. But, in order to be understood, they must use the words available to them. Therefore, their ability to create words is limited. Instead, they rename, adapt, and redefine beginning with their own identification and roles. While carefully preserving their marginalized status as vomen, all three authors invest themselves with powers and prerogatives usually reserved for men. Perpetua, in declaring herself a Christian, metamorphoses from dutiful pagan wife, mother, and daughter to a Christian hero-martyr and, in the process, makes it clear that her relationship to her new god exempts her from traditional Roman and Christian hierarchies and conventions. Dhuoda, who is the most subversive of the three authors addressed in this thesis, redefines her role as a mother and teacher to include the responsibility of spiritual adviser and secular conduct coach. Hildegard, while not relinquishing any of the feminine status and qualities inherent in her role as a Benedictine nun, makes it clear that God has called upon her to perform the duties of an Old Testament prophet in the New Testament Sodom and Gomorrah that twelfthcentury Catholic Europe has become.

Nevertheless, the texts written by Perpetua, Dhuoda, and Hildegard, although they describe women's experiences and express women's ideas, are not essentially different in 
terms of rhetorical structure or syntax from texts written by men under similar circumstances. After all, these women learned to use a male-dominated language the way men used it. However, as pointed out earlier, readers approach a text written by a woman with assumptions that are different from those assumptions on which they base their reading of a text written by a man.

Toril Moi, author of Sexual/Textual Politics, in her description of the work reported by Kramer, Thorne, and Henley, quotes their statement, "Few expected sex differences [in men's and women's use of language] have been firmly substantiated by empirical studies." Moi continues by quoting from a follow-up study reported by Thorne and Henley, "In short, the significance of gestures changes when they are used by men or women; no matter what women do, their behavior may be taken to symbolize inferiority."18 In other words, while the writing may or may not be gendered, readers interpret elements of a text differently if they are aware of the gender of the author. Kramer explains:

Listeners' understanding of what women say and of what men say depends in part upon the listeners' assumptions about what women do and should say and what men do and should say. Women's speech is conceptually and socially, if not in fact, separate from men's speech. ${ }^{19}$

In Hildegard of Bingen: Mystical Writings, Fiona Bowie and Oliver Davies cite an example of how this gender based interpretation happens in the reading of the humility topos ubiquitous in the writing of Dhuoda and Hildegard:.

Both male and female visionary writers of the twelfth century referred to themselves as "weak women", a term which had become a topos of humility, but which, when directed at women by others, was used to disparage their works and to undermine their authority. ${ }^{20}$

In the Middle Ages, the humility topos was used by Christian writers as a reminder to the reader that in relation to God a good Christian is, by definition, a member of a marginalized population, the human race. In this context, the humility topos enhanced the writer's authority as precisely the kind of person God would choose as His obedient servant. 
As a result, in the Middle Ages, women had an advantage in terms of their relationship with God, since by emphasizing their marginal status in relation to men, their use of the humility topos enhanced their marginality.in relation to God: "The dialectic cut both ways: a 'poor little female' could be exalted to miraculous heights only on condition that her normal status remained inferior and subservient." 21 When reading a female author, the twentieth-century reader, however, often takes the phrase literally as a statement of the writer's assessment of her status and ability. When used by her male colleagues, the humility topos is usually read as a rhetorical convention.

The following comments by reputable scholars illustrate how these women's texts have been marginalized by being read as the work of obedient authors with limited ability. Erich Auerbach, in Literary Language and Its Public in Late Latin Antiquity and the Middle Ages, commends Perpetua's text as "expressive" and observes that "she speaks of things that do not occur elsewhere in ancient literature." He nevertheless dismisses her text in terms of its literary value: "Perhaps it will be argued that the Acts of Perpetua are not a literary document. That is true."22 Although all three of the women discussed in this thesis wrote in Latin, Perpetua is the only one Auerbach mentions. Peter Dronke gives Perpetua's text a thorough reading, but he, like Auerbach, focuses on the emotional content of her narrative and emphasizes that the compelling qualities of her writing stem not from her skill as a writer but, as in the cases of "Anne Frank, or the Indian memoir of Mary Tyler, or the prison letters of Angela Davis, in our own time. Where writing wells up out of such fearsome events it seems impertinent or shallow at best, ever to praise the writer's artistry."23 Dronke's sensitivity to Perpetua's situation is honest and scholarly. The question is whether he would dismiss similarly, any consideration of the art of a text written by a man in a similar situation, for example, St. Paul or St. Ignatius.

James Marchand, in "The Frankish Mother: Dhuoda," considers "the very artlessness" of Dhuoda's ㄴanual, as "an earnest of the validity of her writing as a picture 
of the intellectual life of her age," adding that "too often intellectual history turns out to be the history of professional intellectuals," a category that obviously does not include Dhuoda. ${ }^{24}$ While it is true that Dhuoda's text is purported to be a secular, private document, it is clear that, as far as Marchand is concerned, its value lies in the fact that it is an artifact, as opposed to a text whose artistic merit and historical significance should be seriously considered. Margaret Wade Labarge, in A Small Sound of the Trumpet, while admitting that "Dhuoda is ... extraordinary," adds that she is a "rather pathetic figure."25 Gerda Lerner echoes this assessment of Dhuoda: "Her moving conversation with her son is pathetic in its unquestioning acceptance of the fate imposed on her." 26 Chances are that a man in circumstances similar to Dhuoda's would be described as "heroic." It should also be pointed out that personal letters from fathers, whose authority as writers is well established, to their sons, for example such diverse rhetoricians as Cicero and Chesterfield, are often anthologized in history and literature texts.

Hildegard, because of the amount of material she wrote and her authority among her contemporaries, is less vulnerable to such dismissal. However, Matthew Fox, in Hildegard of Bingen's Scivias, observes that "in a 1984 article in the National Catholic Reporter ... she was referred to as a "fruitcake."27 And, according to Barbara Newman, in her introduction to Sister of Wisdom.

There was a time, not very long ago, when St. Hildegard's theological enterprise could be dismissed as a curiosity in church history, and she herself patronized as a token woman and thereby marginalized 28

The issue is not that the scholars quoted here are necessarily wrong, but that their reading is clearly colored by the fact that they are knowingly reading the writing of women and that they have, consciously or unconsciously, dismissed any consideration of the artistic or historic value of these texts.

However, even these readings would not be possible if the reinvigorated women's movement that began in the 1960s had not encouraged scholars to take another look at the 
work of women writers. Only in the last twenty years, with the founding of women's studies programs in the United States, has women's work been examined in depth. For example, Georges Duby and Michelle Perrot, in "Writing the History of Women," explain the dearth of research in women's history by asserting that "What was missing before was the will to know. There can be no history of women unless women are taken seriously and gender relations are believed to influence events and social changes.'29 This assertion is equally true of literature.

The increase in feminist scholarship has also called attention to to the fact that denying the possibility that medieval women might have written anything is another way to dismiss them. Therefore, scholars tend to be more careful about questioning the authenticity of a text just because it may have been written by a woman. Earlier in this century and in preceding centuries, denying that women wrote their texts was a common practice in patriarchal scholarship. Authenticating the authorship is always an issue when considering texts that have survived hundreds of years and been copied and re-edited, not to mention translated, numerous times. However, the issue of authenticity, when the text in question is written by a woman becomes a question of whether or not she has the ability to write anything cogent, much less important:

... Notwithstanding Hildegard of Bingen's meticulous account of her methods of composition, scholars exaggerated the role of her men secretaries to the point of implying that they were the real begetters of her works. ${ }^{30}$

Newman, in the introduction to Columba Hart and Jane Bishop's translation of the Scivias, cites a male scholar writing in 1874 who "maintained that Hildegard transcribed her Latin writings directly from heaven without understanding a word of them."31 Likewise, Katharina M. Wilson, in Medieval Women Writers, points out that it was characteristic for scholars in the centuries following the writing of these women to claim they "were clever forgeries of men."32 There are a few who maintain, for example, that Perpetua's text was entirely the work of the, presumably male, redactor. ${ }^{33}$ The irony, of course, is that when 
questioning the authorship of these texts, scholars attribute their authorship to "heaven" or "clever men." Surely, that in itself attests, not only to a patriarchal reading that insists that a woman could not have written anything remotely coherent but also to a reading that insists that a clever man could have written something readable but incoherent enough to be attributed to a woman. The problem becomes less complex when one asks, "Why would anyone, divine or mortal, do this?" If one wanted to create a credible forgery that would be taken seriously, surely establishing male authorship would be prerequisite. In fact, it might be said that, if the patriarchal critic deems these texts too good to be written by a woman, their writers were more skillful than even some feminists have been willing to acknowledge.

To be sure, these three women are not typical medieval women. Like the men whose documents are considered important in the study of history and included in the literary canon, Perpetua, Dhuoda, and Hildegard were born into aristocratic, influential families and had the advantage of the best educations available at the time. Nor were they strangers to power. Within their domestic arenas and, to some extent, even beyond the boundaries of those arenas, their status and education meant that they served as administrators and governed those (male and female) subservient to them. Their educations added the ability to read and write Latin and placed at their disposal most of the texts known to male scholars, as well as a knowledge of rhetoric, poetry, drama, and logic. Lerner asserts that "the daughters of the elites such as princesses and noble women who might have to serve as stand-ins for sons or husbands, were as carefully tutored and trained as their brothers. ${ }^{n 4}$ This education, of course, means that male thinkers and writers provided the models, tropes, and metaphors available to them, since any earlier female writers would have been dismissed as irrelevant. Newman, in the introduction to the Hart and Bishop edition of Hildegard's Scivias, writes that "although other women had written before [Hildegard], their works had fallen back into silence; the names of Perpetua, 
Egeria, Baudonivia, Dhuoda and Hrotsvitha were unknown to her."35 However, Perpetua, Dhuoda, and Hildegard did not use their male predecessors in lieu of developing their own ideas and forms but rather reworked them to forward their own agendas. This situation poses another problem for women writers, as Gerda Lerner illustrates:

Women who did not know that others like them had made intellectual contributions to knowledge and to creative thought were overwhelmed by the sense of their own inferiority or, conversely, the sense of the dangers of their daring to be different. Without knowledge of women's past, no group of women could test their own ideas against those of their equals, those who had come out of similar conditions and similar life situations. Every thinking woman had to argue with the "great man" in her head, instead of being strengthened and encouraged by her foremothers. ${ }^{36}$

As writing women, they also faced the challenge of adapting the patriarchal discourse system to the expression of women's ideas and descriptions of their experiences. Many late twentieth-century critics and theorists have pointed out that, even for male writers, the correlation between the available discourse system and what a writer wants to say is slippery, especially when the task of interpretation is turned over to a reader equipped with dynamic patterns that may result in unpredictable meanings. When Perpetua, Dhuoda, and Hildegard wrote, the general assumption was that the meaning was in the word and alternative interpretations were the result of misreading. Working within a discourse system considered more than adequate for communicating with the skilled reader, these women often had to wrench their Latin into an odd syntax, use colloquialisms, and occasionally invent words in order to convey anything approaching an accurate sense of what they wanted to say. Thus scholars reading them in subsequent centuries, especially secular scholars suspicious of the religious intensity of these texts, use terms such as "artless" and "literature it is not" to dismiss them from consideration as literature. Chances are, however, that, had these same scholars been reading texts in which male writers found it necessary to distort their Latin in similar ways, these same scholars would look for innovation in style and developmental elements in language and genre. It is likewise 
important, when reading the work of Perpetua, Dhuoda, and Hildegard, to look at what has been read by other scholars as quirks and distortions as, in fact, the art of a writer mastering a challenge not presented to male writers. This approach to literary and historical scholarship asks the reader to read these texts as potentially the work of skilled artists, a reading that may reveal the real contributions these texts can make to history and literature over and above simply representing that segment of the human race whose contributions have been silenced by being ignored. 


\section{ENDNOTES}

1. Male actors in Greek theater were applauded for their skill in convincingly portraying women in women's roles.

2. Gerda Lerner, The Creation of Feminist Consciousness: from the Middle Ages to Eighteen-seventy (New York: Oxford University Press, 1993), 3.

3. Lerner, The Creation of Feminist Consciousness, 4-5.

4. Cheris Kramer, Barrie Thorne, and Nancy Henley, "Perspectives on Language and Communication," Signs: Journal of Women in Culture and Society, 3, 3 (1978): 63851,644 .

5. Nicolae Babuts, The Dynamics of the Metaphoric Field: A Cognitive View of Literature (Newark: University of Delaware Press, 1992), 105.

6. Babuts, The Dynamics of the Metaphoric Field, 113.

7. Mikhail Mikailovich Bakhtin, "From the Prehistory of Novelistic Discourse," in The Dialogic Imagination, edited by Michael Holquist, translated by Caryl Emerson and Michael Holquist, 41-83 (Austin, Texas: University of Texas Press, 1981), 69.

8. Bakhtin, The Dialogic Imagination, 426.

9. Northrop Frye, "The Stage Is All the World," Myth and Metaphor, edited by Robert D. Denham, 196-211 (Charlottesville: University Press of Virginia, 1990), 196.

10. Northrop Frye, Creation and Recreation (Toronto: University of Toronto Press, 1980), 15.

11. Lloyd S. Kramer, "Literature, Criticism, and Historical Imagination: The Literary Challenge of Hayden White and Dominick LaCapra, in The New Cultural History, edited by Lynn Hunt, 97-128 (Berkeley: University of California Press, 1989), 114.

12. Dominick LaCapra, Rethinking Intellectual History: Texts. Contexts, Language (Ithaca: Cornell University Press, 1983), 64.

13. LaCapra, Rethinking Intellectual History, 55.

14. Hayden White, "The Historical Text as Literary Artifact," in Tropics of Discourse: Essays in Cultural Criticism 81-100 (Baltimore: Johns Hopkins University Press, 1978), 91.

15. Peter Dronke, Women Writers of the Middle Ages: A Critical Study of Texts from Perpetua (203) to Marguerite Porete (1310) (Cambridge, Eng.: Cambridge University Press, 1984), viii.

16. Lerner, The Creation of Feminist Consciousness, 48. 
17. Kramer et al., "Perspectives on Language," 644.

18. Toril Moi, Sexual/Textual Politics (New York: Routledge, 1988), 153.

19. Kramer et. al., "Perspectives on Language," 647.

20. Fiona Bowie and Oliver Davies, "Introduction," in Hildegard of Bingen: Mystical Writings (New York: Crossroad Publishing Co., 1990), 44.

21. Barbara Newman, Sister of Wisdom: St. Hildegard's Theology of the Feminine (Berkeley: University of California Press, 1987), 31.

22. Erich Auerbach, Literary Language and Its Public in Late Latin Antiquity and in the Middle Ages, translated by Ralph Manheim (New York: Random House, Inc., 1965), 63.

23. Dronke, Women Writers of the Middle Ages, 16-17.

24. James Marchand, "The Frankish Mother: Dhuoda," in Medieval Women Writers, edited by Katharina M. Wilson 1-29 (Athens, Ga.: University of Georgia Press, 1984), 4.

25. Margaret Wade Labarge, A Small Sound of the Trumpet: Women in Medieval Life (Boston: Beacon Press, 1986), 2.

26. Lerner, The Creation of Feminist Consciousness, 118.

27. Matthew Fox, O.P., "Foreword" in Hildegard of Bingen's Scivias, translated by Bruce Hozeski (Santa Fe: Bear and Co., 1986), xxiii.

28. Newman, Sister of Wisdom, xv.

29. Georges Duby and Michelle Perrot, "Writing the History of Women," in $\underline{A}$ History of Women in The West: From Ancient Goddesses to Christian Saints, edited by Pauline Schmitt Pantel, translated by Arthur Goldhammer, ix-xxi (Cambridge: Harvard University Press, 1992), xv.

30. Dronke, Women Writers of the Middle Ages, ix.

31. Barbara Newman, "Introduction," in Hildegard of Bingen, Scivias, edited by Columbia Hart and Jane Bishop, 9-53 (New York: Paulist Press, 1990), 53.

32. Wilson, Medieval Women Writers, xix, xxvii, asserts that "the most fascinating question about women writers of the past concerns how they differed from their female successors and from their male contemporaries. In contrast with women writers of the more recent past, medieval women writers did not use male pseudonyms but identified themselves by name and by sex. In addition, unlike the works of women writers of the seventeenth, eighteenth, and even nineteenth centuries, those of medieval women provide little evidence that they were ridiculed for or prevented from accomplishing their literary endeavors (when there is criticism, it usually concerns the authenticity of their mystical experiences, not their right, willingness, or ability to record them). Imputations that their 
works were clever forgeries of men stem from subsequent centuries." In note no. 72 , Wilson observes that "The works of Hrotsvit and Heloise, just to mention two, were labeled forgeries in centuries following the Renaissance; this possibility does not seem to have occurred to their medieval audience."

33. Cecil M. Robeck,Jr., Prophecy in Carthage: Perpetua. Tertullian and Cyprian (Cleveland: Pilgrim Press, 1992), 16. Robeck cites David Scholer who suggests that even the redactor may have been a woman. Unfortunately, according to Robeck, Scholer provides no evidence nor reasons for making this claim.

34. Lerner, The Creation of Feminist Consciousness, 23.

35. Newman, "Introduction," 9.

36. Lerner, The Creation of Feminist Consciousness, 12. 


\section{CHAPTER II}

\section{DIALOGUE IN THE FACE OF DEATH \\ PERPETUA: CHRISTIAN MARTYRDOM IN GREEK TRAGEDY METAPHORS}

Back to their source the holy rivers turn their tide. Order and the universe are being reversed. "Tis men whose counsels are treacherous, whose oath by heaven is no longer sure.... Honour's dawn is breaking for woman's sex; no more shall the foul tongue of slander fix upon us. The songs of the poets of old shall cease to make our faithlessness their theme. Phoebus, lord of minstrelsy, hath not implanted in our mind the gift of heavenly song, else had I sung an answering strain to the race of males, for time's long chapter affords many a theme on their sex as well as ours. Euripides, Medea 430-45.

Euripides wrote Medea slightly less than six hundred years before Vibia Perpetua and her fellow Christian converts were set upon by beasts and executed in the arena in Carthage on March 7, 203 A.D. Medea was culturally available to Perpetua as an icon of the evil that results when a woman refuses to remain in the house--muted and inconspicuous. Unlike Medea, Perpetua did not choose to come forth.from the house; her arrest and subsequent execution made her entry into the public arena inevitable. However, she did choose to construct a narrative describing her experience. The evidence presented in this chapter indicates that Perpetua, perhaps without being aware of it, patterns the story of her martyrdom on another Euripidian hero, Iphigeneia. Iphigeneia, as she is portrayed in Euripides's play, Iphigeneia at Aulis, is obliged to come forth from the house as a public sacrifice. Rather than play her public role as a helpless victim, Iphigeneia chooses to rewrite herself as a Greek hero. In a remarkably similar fashion, Perpetua uses the events of her martyrdom as an opportunity to enter deliberately the public discourse arena as a Christian hero dying for her faith. Her description of her life following her arrest and of the the visions she has during her imprisonment has been preserved, and, with the help of 
theologians, she has been read as the quintessential Christian martyr for nearly two thousand years.

In 202 A.D., the Emperor Septimus Severus issued a decree forbidding proselytism. Under this decree, Romans who converted to either Judaism or Christianity were subject to prosecution and sentence of death unless they renounced their new religion. ${ }^{1}$ Perpetua, the daughter of aristocratic Roman parents and a native of Carthage, was arrested and eventually executed under the provisions of this decree. As she and her five Christian prison companions waited for the inevitable sentence and the day when they would enter the arena Perpetua documented her experience in writing. The contents of this narrative, and another martyr's vision, framed by an anonymous redactor comprise, The Passion of Saints Perpetua and Felicitas. ${ }^{2}$

Thomas J. Heffernan, in Sacred Biography, describes The Passion as "the primal document in the development of the conventions which were to shape female sacred biography for a millennium." 3 Heffernan identifies these conventions as "the redefinition of ideas of kinship; freedom from the Pauline notion of sexual indebtedness; the importance of prophetic visions; and the change from virgin, wife, or widow to the Bride of Christ."4 Heffernan observes that "all of these categories exist in the Latin text of the Passio Sanctarum Perpetuae et Felicitatis." 5 Whether Perpetua or the women writers who followed her consciously realized the importance of redefining their traditional female roles, the fact that such redefinition was an essential rhetorical element of their writing indicates an awareness on some level of the necessity to rework the language.

The Passion gives the reader a picture of a bold, brave woman who resolutely refuses to renounce her belief in Christianity and marches into the arena singing hymns. Church fathers and theologians have promoted this interpretation of The Passion despite the fact that Perpetua's behavior, as described in her account, defies both pagan and Christian definitions of what is proper and appropriate for women. As Perpetua portrays herself in 
her narrative, she rejects both civil and parental authority and assumes considerable authority herself, including the power to authenticate her own prophetic visions and to baptize her younger brother posthumously. In the process of assuming authority, Perpetua inverts many of the pagan and Christian assumptions underlying gender definitions. Nowhere in her text does she demonstrate the Christian concept of hurniliigy based on the example of Christ. Yet, even St. Augustine, writing within two hundred years of Perpetua's death, presents her as an exemplar of Christian martyrdom.

Although Perpetua and her redactor often remind the reader that Perpetua is obeying God's will, many of her actions, when analyzed in terms of third-century Christian theology, are unorthodox. In fact, each of the conventions Heffernan identifies as "shap[ing] female sacred biography for a millennium," challenges Christian doctrine and violates both pagan and Christian strictures on female behavior. Nevertheless, when the redactor assumes the task of completing the account of Perpetua's execution, he sustains and magnifies these aspects of her behavior. And he is careful to make sure the reader understands that he is following Perpetua's instructions: “... though we are unworthy to finish the recounting of so great a glory, yet we accomplish the will of the most holy Perpetua, nay rather her sacred trust" (The Passion, 16, 36).

The Passion also reveals an intelligent and talented female author, an active artist consciously constructing a narrative in which she demonstrates for her readers what she believes are the essential rhetorical elements of Christian martyrdom. Many of the rhetorical elements Perpetua uses to describe her martyrdom have parallels in Greek tragedy, a genre prevalent in Perpetua's Roman culture. Because Greek tragedy was part of Perpetua's "language world" metaphors and tropes from specific plays would be among the "dynamic patterns" available to Perpetua, subconsciously as well as consciously, as she identified and interpreted her situation. These observations suggest the possibility of a 
dialogic reading of The Passion, a reading that considers what specific plays may have informed the structure of Perpetua's narrative and her portrayal of herself.

The metaphors and patterns that enabled Perpetua to interpret and understand her life prior to her arrest would, by comparison to her prison environment and death sentence, have intensified her anguish and terror. The conditions of her imprisonment would have been a stark contrast to her accustomed environment as a young, upper-class matron. The realization that she must deny her Christianity and her faith in God or be humiliated and painfully executed in the arena would have been stark and horrifying. It is clear in The Passion that metaphors and patterns surfaced in Perpetua's memory that helped her to redefine her situation in terms that lessened debilitating emotions. In an effort to make meaning out of this unalterable reality, Perpetua possibly found those workable metaphors and patterns in a specific Greek tragedy. A Greek tragedy that provides a substantial number of the rhetorical elements found in The Passion is Euripides's Iphigeneia at Aulis. The presence of parallels between Iphigeneia and Perpetua as doomed female heroes and the use of similar rhetorical elements in both narratives suggest the possibility that, at some level, Perpetua's memories of Iphigeneia at Aulis informed the creation of her text. Thus, as the image of the Greek female tragic hero emerges with Perpetua's version of a Christian martyr, she writes a story that, in spite of the unorthodox behavior described, is useful for Christian proselytizers in the Roman Empire because it presents a picture of Christian martyrdom that is more appealing to pagan Greco-Roman sensibilities than the passive imitatio Christi model prevalent in other parts of the Roman Empire. The absence of a clearly defined imitatio Christi pattern in Perpetua's Christian culture and the fact that the metaphors and dynamic patterns of her pagan, classical background would have been more firmly embedded in her memory than the Christian patterns and metaphors that were relatively new to her also explains why Euripides's Iphigeneia would have been more 
readily available to Perpetua than the model of personal humility familiar in the accounts of St. Ignatius and the martyrs of Lyon.

But The Passion of Saints Perpetua and Felicitas is more than a rhetorical fusing of cultural tropes written by a woman. By documenting her move from the private to the public sphere, Perpetua becomes an active vocal hero rather than a silent passive victim. By writing her story instead of leaving it to be told by the church fathers and by circumventing convention rather than submitting to it, Perpetua creates the first extant Christian narrative of the "self-as-hero." Perpetua's interpretation of martyrdom illustrates the Christian redefinition of classical tragedy that ends in death and lasting fame as rebirth and the marriage of the Church and Christ. As the paradigm for female martyrdom and hagiography, The Passion occupies a unique position in women's history and literature.

While Perpetua remains part of the modern Catholic calendar, her text has largely been ignored by literary scholars and historians. There are several reasons for this neglect. As Heffernan observes, saints' lives have "until recently fallen through the net of scholarly research, avoided by the historians because [they lack] 'documentary' evidential status and by the literary historians because saints' lives are rarely works of art."6 Furthermore, the deeds recounted in these biographies are often outrageous and unbelievable. One trip through the "fiery ovens" or flight to the tree tops with Christina Mirabilis illustrates why historians have dismissed these texts. In other texts, actions that are depicted as exemplary or motives as inspired by faith seem more wicked than saintly to modern eyes. For example, Angela of Foligno in 1248 A.D. claims to have prayed for the deaths of her husband and children in order to be free to dedicate her life to Christ. She then explains that, as a result of her prayer, "within a short time after this my husband and all my children were dead," and she concludes, "I felt great consolation at their deaths." Not surprisingly, critics, especially feminist critics and theorists, have had difficulty dealing with such a female writer. Texts describing such bizarre behavior, even if done for higher 
motives, present serious problems for feminists trying to establish the credibility of women's contributions to literature and history as defined by men for whom rational thought, logic, and emotional stability are a priority. It is, however, the early Church's endorsement of Perpetua's disobedience that enables this fascinating and unorthodox woman and others not only to tell their stories but also to be honored and even sanctified in spite of what might seem unconventional behavior.

In Perpetua's text, there are also disturbing elements that have probably contributed to its neglect. At the center of Perpetua's narrative is her sincere desire to be an actor in her sacrifice rather than a passive victim in the name of her religion. As she turns toward God and the next world, she turns away from a father who loves her and a baby who needs her. Perpetua's behavior, as depicted in the text, often seems unsympathetic. She never mentions her husband, barely refers to her mother, and inverts the traditional authoritative relationship between men and women, especially in her descriptions of her interaction with her father. This last rhetorical move seems particularly harsh to twentieth-century readers. Yet she casts herself as a compassionate and loving woman.

As she describes these actions, she carefully and repeatedly informs her reader that she recognizes the love that her family has for her and the pain that they suffer as she turns her back on them. Perpetua opens her segment of the text by describing her father's efforts to "hurt [her] faith" in order to cause her to recant her religion "because of his love [for her]." She describes herself as filled with "torment" for her baby and "strengthen[ing her] brother." She describes her father as "wom with worry" and "overwhelmed with sorrow." Her claim to compassion is explicit when she says, after her family visits her in prison, "I pined because I saw they pined for my sake" (3., 24-25). By voicing her love, anxiety, and suffering for her family Perpetua carefully creates a compassionate and sympathetic persona while her actions, to a modern reader, appear self-centered and heartless. For the third-century Christian convert, however, Perpetua's description provides the exemplum of 
the stoic bravery with which one must endure the entreaties of loving pagan family members. This rhetorical move also provides the model for what Heffernan refers to as one of the conventions found in female sacred biography for the next twelve hundred years: "the redefinition of the ideas of kinship." Embedded in The Passion is the rhetorical model for Angela of Foligno's dismissal of her family a thousand years after Perpetua turns her back on her father and son.

Perpetua's behavior towards her family and the gruesome descriptions of the ordeals in the arena are jarring, even for readers who understand the religious conviction underlying Perpetua's actions. For this reason and the fact that these events are depicted in a work labeled hagiography, Perpetua's text, like the narratives of Christina Mirabilis and Angela of Foligno, has been overlooked by most scholars. Because hagiography is, by definition, the biography of an obedient saint whose religious intensity takes precedence over the accurate description of her life, scholars assume the narrative lacks the credibility necessary to be considered more than a literary or historical curiosity. As a result, The Passion's striking contributions to literary tradition and women's history have been, for the most part, underplayed.

The Passion has been preserved by the Catholic Church, and Perpetua is one of the saints petitioned in the Easter Vigil. The early Church treated her visions as authoritative, considered her the epitome of an obedient female saint, and deemed her life worthy of imitation. Perpetua's bishop, Tertullian, considered by many scholars to be the most misogynistic of the Church Fathers, calls Perpetua "that most heroic martyr" and cites her last vision as an authority on the composition of Heaven: "How is it that Perpetua ... on the day of her passion, in a vision of Paradise, saw only martyrs there?"8 The anniversary of Perpetua and Felicity's martyrdom was listed in the official calendar of the Church in Rome in 354 A.D. It was also included in the late fourth-century Syriac calendars, the Martyrology of Jerome, and later in the Canon of the Mass of the Latin Christian Church. 
Archaeological evidence indicates that by the fourth century, and perhaps before, a basilica was dedicated to Perpetua at Carthage, and the discovery of inscriptions at other locations demonstrates that she was honored at an even earlier date.9 Augustine, Bishop of Hippo, preached three sermons on March 7 of different years in Carthage, to commemorate Perpetua and Felicity's martyrdom on that date in that city. ${ }^{10}$ In one of those sermons, Augustine writes:

Today with its anniversary and return calleth into our mind, and in a manner setteth anew before us, that day whereon the blessed servants of God, Perpetua and Felicity, being adorned with the crowns of martyrdom, did achieve the flower of perpetual felicity; bearing in the battle the name of Christ, and in the prize of battle finding their own. Their exhortations in the heavenly visions, and the triumphs of their passion we heard when they were read to us; and all these, set out and made clear with the light of words.... For what thing might there be more glorious than these women, whom men may wonder at sooner than they may imitate? 11

Augustine also indicates familiarity with the Passion by quoting and paraphrasing it frequently 12 and, according to Heffernan, was particularly eager "to establish" this text's "status as paradigmatic."13

The Passion consists of four parts: a section that the redactor says is Perpetua's , ["What follows here she shall tell herself; the whole order of her martyrdom as she left it written with her own hand and in her own words" (2, 23-24) (3-10)], another section written by her fellow martyr Saturus (11-13), ${ }^{14}$ and an introduction and conclusion written by the anonymous redactor (1-2 and 14-21). In the second paragraph of the introduction, the redactor sets the stage for Perpetua's narrative:

There were apprehended the young catechumens, Revocatus and Felicity his fellowservant, Saturninus and Secundulus. With them also was Vibia Perpetua, nobly born, reared in a liberal manner, wedded honourably; having a father and mother and two brothers, one of them a catechumen likewise, and a son, a child at the breast. (2, 23)

The catechumens were baptized shortly after their arrest. Saturus, the person responsible for their conversion, "who afterwards had of his own will given up himself for our sakes, because it was he who had edified us; and when we were taken he had not been there," 
joined the group in prison in what can only be described as an act of voluntary martyrdom $(4,26)$. After questioning by "Hilarian the procurator" and a "confession of faith," they "were condemned to the beasts" $(6,28)$. Once sentenced, they "were transferred to the camp prison" having been sentenced to "fight with the beasts at the camp games ... and the time was the feast of Geta Caesar" $(7,29)$. In the arena, Perpetua and her companions battled the beasts, and those not killed in battle were beheaded by Roman soldiers.

Perpetua's aristocratic background provides her with the classical models, metaphors, and rhetorical patterns she brings together to make meaning out of her Christian martyrdom. Perpetua is a woman caught between two cultures: the pagan Roman world of Carthage in which she was born and raised in the privileged world of an aristocrat and her newly embraced Christian community. According to Frank Pierrepont Graves, daughters of upper-class Roman parents were "often given considerable" education. Educated upperclass girls "attended the same elementary schools as the boys." Musonius Rufus, a Roman philosopher (ca. 65 A.D), believed that girls and boys should receive the same education:

Women have received from the gods the same ability to reason that men have. We men employ reasoning in our relations with others and so far as possible in everything we do, whether it is good or bad, or noble or shameful .... Women are pleased no less than men by noble and just deeds, and reject the opposite of such actions. Since that is so, why is it appropriate for men to seek out and examine how they might live well, that is, to practise philosophy, but not women? Is it fitting for men to be good, but not women? ${ }^{15}$

William V. Harris in Ancient Literacy, argues that "in a small Greek town in Egypt in the second century, girls' schooling was not unknown," but he adds that, "almost everywhere male pupils vastly outnumbered female ones."16 Most scholars agree with this assessment, but as Sarah B. Pomeroy states, in her essay "Women in Ancient Egypt," "some women in Roman Egypt were literate and, like women elsewhere in the Empire, most of them probably acquired their knowledge in school."17 Pomeroy also cites specific examples of literate women and notes that some scholars have observed that there was "a small rise in the percentage of literate women in the second and third centuries."18 According to Harris, 
the education these women received included Homer and Euripides: "The papyri show conclusively that popular literature did not exist in any ordinary sense of that expression: the literary texts which were most copied were the classics, Homer and Euripides."19 Pomeroy reports on a survey that seemingly supports this assumption:

According to the survey of R. A. Pack, Euripides was next [after Homer] with 79 texts. Euripides was probably chosen more frequently as a school text than Sophocles or Aeschylus for several reasons including the greater simplicity of his language. But apparently there was an interest in heroines like those of Euripidean tragedy. ${ }^{20}$

Educated Romans, male and female, also learned to read and write both Latin and Greek.

H. I. Marrou in A History of Education in Antiquity observes: "In Latin-speaking districts, the bilingual system of education instituted in the second century B.C. had never been challenged, and it lasted in theory as long as the ancient tradition itself." 21

One of the tasks set for students in the Greek and Roman elementary schools from "Isocrates in 390 B.C. to St. Augustine in c. 400 A.D. was to learn to imitate the authors they were studying. Donald Lemen Clark, in Rhetoric In Greco-Roman Education, claims that "belief in the value of imitation was undeviating [during this long time period]." This belief in the value of imitation is exemplified by the "exercise of impersonation" used in elementary instruction. Clark explains this exercise:

The exercise of impersonation, most usually termed prosopopeia, required the pupil to compose an imaginary monologue which might appropriately be spoken or written by a historical, legendary, or fictitious person under given circumstances. Hermogenes subdivides the exercise into three varieties: Ethopeia is an imitation of the character of a person assigned--what words Andromache might say to Hector. The exercise is called prosopopoeia when we put the person into the scene, as in Aristides the sea is imagined to be addressing the Athenians. ... As the future public speaker was nourished by the poets in the grammar school, so we see poetical theory and practice nourished by the elementary exercises in rhetoric. That such a relationship does exist between poetry and prosopopoeia Quintilian fully recognizes: "Prosopopoeia [as an exercise] greatly improves the powers of those who would be poets or historians" (III. viii. 49). And he adds, "Nor am I ignorant that poetical and historical prosopopoeia are sometimes given in the schools by way of exercise, as the pleading of Priam to Achilles, or the address of Sulla to the people on laying down the dictatorship." The Heroides of Ovid, who had been trained in the school exercise, are excellent examples of what words Dido might say to Aeneas or what Medea might say to Jason. ${ }^{22}$ 
This academic exercise has its roots in Aristotle who explains in the Poetics, “. . From childhood ... he [a human being] is the most imitative of living creatures, and through imitation he learns his earliest lessons." Aristotle also adds, "Thus the reason why men enjoy seeing a likeness is, that in contemplating it they find themselves learning or inferring, and saying perhaps, 'Ah, that is he."'23

By doing school exercises such as the ones described above, Perpetua could have learned the stories told in Euripides's plays and also a great deal about the characters and how Euripides constructed a play. It is, therefore, possible to conjecture that, in determining her course of action as a Christian martyr, Perpetua found her model in a Greek tragedy by Euripides. Given the fact that the metaphors embedded in Iphigeneia's story resonated with Perpetua's situation and the fact that Iphigeneia at Aulis was culturally available to her, it is not surprising to find rhetorical elements of Euripides's play skillfully woven into Perpetua's narrative. Babuts theories about the metaphoric field explain how the parallels between Perpetua's situation and Iphigeneia's may have surfaced in Perpetua's memory:

... the process is set in motion by a detail from the present perceptual field ... a dynamic pattern, a bold metaphor, which attracts its corresponding mnemonic sequence and alerts others in the background preparing them to contribute to the creation of a new field. ${ }^{24}$

The stark reality of the death sentence that followed Perpetua's refusal to renounce her faith, would be a dramatic enough event to activate the complex dynamic patterns stored in her memory as a result of her school exercises and bring them together as a metaphor for Perpetua's definition of her experience.

The phenomena described by Babuts then explains the presence in both texts of several important rhetorical elements that are similar. Following the realization that she could not change her fate and that her dramatic execution inevitably made her a public figure, Perpetua decided that she could interpret it and control how it was perceived by 
others in much the same way that Iphigeneia turned her inevitable sacrifice into an act of heroism. Like Iphigeneia, Perpetua, aware of her station in life, understood the importance of conducting herself with dignity and honor in public and avoiding public humiliation. Because Perpetua knew Iphigeneia through the text of Euripides's play as well as through theatrical performances, may also have suggested to Perpetua the possibility of writing her own narrative as a way of making sure that she would be remembered the way she wanted to be remembered.

In Euripides's play Iphigeneia at Aulis, Iphigeneia comes to Aulis thinking she is to marry Achilles. The truth, as it is revealed in the opening scene, is that her father, Agamemnon, has promised her as a sacrifice to the goddess Artemis who is preventing Agamemnon's troops from sailing to Troy to reclaim Helen and destroy the city. ${ }^{25}$ They are unable to sail from Aulis because Artemis refuses to provide a wind to fill the sails of the Greek ships.

When Iphigeneia learns that she has come to Aulis to die rather than be married, she and her mother, Clytemnestra, beg Agamemnon to change his mind (1120-1250). When Agamemnon explains why her sacrifice is necessary (1255-1275), Iphigeneia decides not only to accept it but to reconstruct her role by choosing to die for the good of her father's cause and her country's honor (1370-1400) and in the process to be remembered as a Greek hero. By making Iphigeneia willing to be sacrificed, Euripides can allow Iphigeneia to come forth from the house and assume the male prerogative of fame. In order to dramatize this metamorphosis, Euripides portrays Iphigeneia as initially frightened and begging to live. Iphigeneia, kneeling on the ground and clutching Agamemnon's knees begs him for her life:

Look, this flesh is alive, because of you!

Because you made a child--because this woman [Clytemnestra] bore

That child. This life you made is in its springtime--

Don't destroy it!

The light of the sun in my eyes is so sweet-- 
Don't make me see what lies beneath the earth.

(1215-1220)

Like Iphigeneia, Perpetua also expresses fear during her first days in prison, but her fear stems from the wretched conditions of the prison, which must have been a shocking contrast to anything she had experienced before her arrest. Perpetua describes her own terror and the prison in language that evokes the pagan image of hell: a place not unlike the place she describes in a vision she has sometime later of her brother Dinocrates..

A few days after we were taken into prison, and I was much afraid because I had never known such darkness. O bitter day! There was a great heat because of the press, there was cruel handling of the soldiers. (3., 24-25)

Her portrayal of the prison as "darkness" suggests that mentally she is already seeing what Iphigeneia begs not to, "what lies beneath the earth," and she fears the truth of Iphigeneia's claim:

The most beautiful sight in the world is the sun shining.

Beyond this life is ... nothing.

Only a madman hopes to die. Life, even a life

Of misery, is better than any glorious death!

It is Perpetua's pagan father, rather than Perpetua, who echoes Iphigeneia's horror and regret at a young life cut short. Her father expresses his feelings of love and incomprehensible impending loss in one of his several efforts to persuade her to renounce her Christianity:

Have pity, daughter, on my grey hairs; have pity on thy father, if I am worthy to be called father by thee; if with these hands I have brought thee unto this flower of youth--and I have preferred thee before all thy brothers ... (5., 27)

Perpetua never describes herself as pleading for clemency. By describing her nonChristian father's natural reaction to her choice to die rather than to renounce her Christian faith, maintains her persona as a stoic Christian martyr and masks any personal feelings she may have had that were similar to those expressed by Euripides's Iphigeneia. 
Initially both Perpetua and Iphigeneia, as they are portrayed in their respective texts, accept the marginalized position defined for women. After Agamemnon refuses her pleas for mercy, Iphigeneia wants to retreat from the stage into the house: "Open the doors, someone, I mustn't let myself be seen" (1339). Clytemnestra, insisting that Iphigeneia remain on stage, points out, "No! You can't escape into fine feelings now" (1340). Iphigeneia remains on stage and listens to Clytemnestra and Achilles discuss the Greek army's eagerness to have Iphigeneia sacrificed so they can proceed to Troy. During their conversation, she makes the decision metaphorically to "come forth from the house." No longer wanting to hide from her fate, she boldly interrupts Clytemnestra and Achilles by saying, "Mother, I want to say something to you, and you / Must listen" (1367-8). Having made the decision to be sacrificed, she explains to Clytemnestra how her death will transform her from a private domestic woman into a public female hero.

I must die .... No, it is settled! It is what I want-To do something. ... something fine, and noble, And shed all that is mean and little in my nature.

Greece is a very great nation, and every eye

In Greece is turned on me... .

By dying I shall make sure that Greece survives, And, with Greece, the story of what I did. Greece will be free; I shall be happy--no god In heaven could be happier! $(1375-1383)$

Like Iphigeneia, Perpetua initially wants to retreat. Before her first vision, Perpetua describes prison with her baby as a palace and says it is the only place she wants to be. After the vision, Perpetua tells her father: "That shall be done at this tribunal, whatsoever God shall please; for know that we are not stablished in our own power, but in God's" (5., 27). A few days later, she publicly defies both her father and Hilarius, the Roman proconsul, and declares her Christianity. At this point she also lets her father keep her baby, the one part of her private identity remaining in her life. For Iphigeneia, her sacrifice means a man's fame as a hero who saves her country's honor. For Vibia Perpetua, her 
Christian martyrdom means life everlasting in Paradise and the possibility, like Iphigeneia, of being remembered and honored as her text is read by those who come after her.

Regarding women's roles and behavior, Perpetua's emerging Christian culture retained the Roman and Jewish conventions based on the traditional assumption that women are inferior to men and should be ruled by them. In both cultures, "good" women stay home and perform their domestic functions in silent obscurity. The warning in Euripides's Medea that only evil, malevolent women come forth from the house to take their place brazenly in the public discourse arena is manifest in numerous pagan descriptions of what is expected of women. According to Sophocles and Aristotle, silence is the essential adornment of women. In Sophocles's Ajax, "Woman, for women silence is grace," is the "eternal refrain" with which Ajax answers Texmessa's questions. ${ }^{26}$ Aristotle asserts that "a modest silence is a woman's crown."27 Pericles, as Thucydides reports his funeral oration, extolls the virtues of silence and obscurity to the widows of the dead Athenian soldiers : "Your great glory is not to be inferior to what God has made you, and the greatest glory of a woman is to be least talked about by men, whether they are praising you or criticizing you."2s

Five centuries later, Roman women enjoyed more freedom than Greek women, but there were still many restrictions on their roles and behavior in society. Juvenal, the Roman satiric poet writing in the first-century A.D.,warned against a public role for women:

Wives shouldn't try to be public speakers; they shouldn't use rhetorical devices; they shouldn't read all the classics--there ought to be some things women don't understand. ... If she has to correct somebody, let her correct her girl friends and leave her husband alone. ${ }^{29}$

Like Juvenal, St. Paul's opinions on the position and participation of women in the early Church are based on the same restrictive assumptions that support the pagan view of 
women. These assumptions are reinforced by the events in the Garden of Eden described in Genesis. In a letter to Timothy, Paul explains the role of Christian women:

Let a woman learn in silence with all submissiveness. I permit no woman to teach or to have authority over men; she is to keep silent. For Adam was formed first, then Eve; and Adam was not deceived, but the woman was deceived and became a transgressor. Yet woman will be saved through bearing children if she continues in faith and love and holiness, with modesty. ${ }^{30}$

In First Corinthians, Paul makes it clear that women are expected to be silent, even in the

Church:

As in all the churches of the saints, the women should keep silence in the churches. For they are not permitted to speak, but should be subordinate, as even the law says. If there is anything they desire to know, let them ask their husbands at home. For it is shameful for a woman to speak in church. What! Did the word of God originate with you, or are you the only ones it has reached. (1. Cor, 14: 35-36)

However, unlike Medea, Iphigeneia and Perpetua, when they decide to come forth from the house and become public figures, are praised by men rather than condemned. But, only by publicly embracing death instead of resisting it or meekly accepting it. As Perpetua creates her narrative, other rhetorical elements from Euripides's version of Iphigeneia surface in her text. While unable to change her sentence, Perpetua, like Iphigeneia, controls the interpretation of her situation. As both women turn away from traditional domestic roles and relationships, they create for themselves a heroic new role as sacrifice-martyr and replace their traditional family relationships with an intensified allegiance to a spiritual authority.

One's word as the name that defines a person and as promises that are binding is a fundamental rhetorical principle in both pagan and Christian cultures. An individual's reputation, the words others say about him, are based on how well a person's actions represent his definition and fulfill his promises. In Greco-Roman culture, as Agamemnon demonstrates when he snaps at Menelaus, a name defined a man's role in life: "What do you see? My father's / name meant / 'He who does not show fear.'Do I?' (321-2). And as the chorus explains at the end of the first epeisodion: 
... And to see what is right,

To see and understand is a gift of grace

That transforms the world,

And on the spot the word is born,

The word that cannot die -- fame. A good name.

Your life's reward.

The greatest prize you can pursue. (564-69)

Perpetua opens her narrative with a rhetorical stance similar to Agamemnon's response to Menelaus. In her response to her father's efforts to dissuade her from declaring herself a Christian, she points to a vase and asks, "Can it be called by any other name than that which it is?" "No," he replies. Perpetua then explains what her promise to be a Christian means in terms that rename her: "So can I call myself nought other than that which I am, a Christian." According to Perpetua, "Then my father moved with this word came upon me to tear out my eyes" $(3 ., 24)$. In this compact sentence, Perpetua eliminates the possibility of any other motives for her father's anger except her emphatic definition of herself as a "Christian." Just as Agamemnon must live up to his name, "one w'ho does not show fear," Perpetua has pledged to be one who belongs to Christ. In Euripides's play, Iphigeneia's sacrifice is made necessary by Agamemnon's promise to Artemis because Agamemnon's reputation and the honor of Greece depend on their participation in the Trojan War. Agamemnon's ability to keep his promise depends on Iphigeneia's commitment to him as his dutiful daughter.

Perpetua's Christian God is described in Genesis as "the Word." His words, "let there be," bring into being all the elements of the natural world. Jesus Christ, according to the Bible, is "the Word ... made flesh ... begotten of the Father" (John 1:14) and the fulfillment of God's promise of life and resurrection (Eph. 3:6) the promise of a god who "keepeth covenant and mercy." Perpetua, like Agamemnon, has made a promise to a god. Having been baptized a few days after her arrest, Perpetua is bound by the first of the Ten Commandments, the Decalogue, "'You shall have no other gods before me" (Deut. 5:7). 
Under Roman law, if she keeps her promise to her Christian god, Perpetua must be executed, just as Iphigeneia must be sacrificed in order that Agamemnon may keep his promise to Artemis. Iphigeneia, when she decides to embrace her sacrifice, is no longer Agamemnon and Clytemnestra's dutiful daughter. She becomes a Greek hero dying for her country. When Perpetua makes the same decision, she redefines herself as a Christian hero actively demonstrating courage and nobility as she faces the ultimate test of faith. She rhetorically, as well as emotionally, redefines her relationship with her biological family and becomes a member of a spiritual family.

While Euripides provides Agamemnon with the seer Calchas, who explains to him why the gods have cursed Aulis with an extended calm, Perpetua rewrites herself as her own oracle by going directly to God via a vision in order to learn her fate and that of her fellow prisoners. Perpetua writes that another Christian prisoner, whom she calls "brother," says to her: "Dear sister, you are greatly privileged; surely you might ask for a vision to discover whether we are to be condemned or freed." Perpetua, anticipating no problem in receiving a vision, explains to her reader, "I knew that I could speak with the Lord, whose great blessings I had come to experience." She promises her fellow Christian that she will seek to discover whether they were to be "condemned or freed." Perpetua's self-assured response to her "brother's" request echoes Iphigeneia's assertiveness when she interrupts Clytemnestra and Achilles to announce her decision to be sacrificed. Absent in Perpetua's statement is the humility topos that would replace Perpetua's overt confidence in the writing of later medieval visionaries. She does, however, acknowledge that her brother, a man, suggests that she request a vision and verifies her spiritual privilege. The inclusion of this detail indicates that Perpetua was perhaps aware that male authorization of some sort was necessary in order to authenticate her spiritual communication and guarantee that her visions were not satanic delusions. Unlike her medieval successors, Perpetua, however, seems unaware of the possibility of the latter. 
In her ensuing vision, she climbs a ladder into heaven where she is greeted by an old shepherd. As Robeck explains, "At the very least the shepherd of Perpetua's vision can be described ... as an epiphany of a divine being."' 1 The shepherd informs her that He is "glad she has come." She interprets this vision to mean that it is God's will that she die. After explaining the vision to her brother, she writes, "We knew it should be a passion; and we began to have no hope any longer of this world" (4., 27). In an endnote for his introduction to Perpetua's dreams, Robeck quotes Patricia Cox Miller: "Perpetua betrays her oneness with her culture, which understood dream-speech as a kind of divine logic." Robeck goes on to say that "On the other hand, she [Cox Miller] observes that Perpetua shapes later tradition with her interpretations and descriptions, using her dreams/visions to some extent as 'a mode of scriptural exegesis as well as a vehicle for theological reflection.'32 There is no way of knowing how much Perpetua learned in her Christian education about the biblical tradition of prophetic and apocalyptic visions, but it is probable that her use of visions in The Passion combines the pagan practice of divination with what she knew about Christian prophecy. It is her visions in The Passion, however, that, as Heffernan points out, establish "the importance of prophetic visions" in female hagiography. 33

Soon after her public declaration of Christianity, Perpetua has two visions concerning her younger brother, Dinocrates, who died when he was seven years old. In them, Dinocrates is apparently taken from hell and baptized as a result of Perpetua's intercession. While praying for Dinocrates, Perpetua "straight-way" received a vision of him in a pagan hell. She describes Dinocrates and the spirits with him as being in a dark, hot place where they are dirty and thirsty but unable to reach the only available water. The wounds that Dinocrates had on his face at his death had never healed. When Perpetua "awoke [she] knew that [her] brother was in travail. Yet [she] was confident [she] should ease his travail; and [she] ...made supplication for him day and night with groans and 
tears, that he might be given me" (7., 29-30). In her next vision, Perpetua learns that her prayers have been effective:

I saw that place which I had before seen, and Dinocrates clean of body, finely clothed, in comfort; and the font I had seen before, the edge of it being drawn down to the boy's navel; and he drew water thence which flowed without ceasing. And on the edge was a golden cup full of water, and Dinocrates came up and began to drink there-from; which cup failed not. And being satisfied he departed away from the water and began to play as children will, joyfully. And I awoke. Then I understood that he was translated from his pains. $(8,30)$

Perpetua is implicitly claiming that as a result of her prayers her dead pagan brother has been cleansed of his sins and baptized. The claim is unorthodox for two reasons. According to Christian doctrine as established by St. Paul and by Perpetua's own bishop, Tertullian, the unconverted dead cannot be baptized and, even if that were possible, Perpetua, as a woman, does not have the authority to baptize anyone. ${ }^{34}$ Tertullian, in Baptism (ca. 200 A.D.), makes the church's position on this point very clear:

But if those writings which are wrongly called Acts of Paul defend the example of Thecla as a license for women to teach and baptize, let them know that in Asia the presbyter who composed that writing, as if he were augmenting Paul's fame from his own, after having been convicted and having pleaded that he did it out of love for Paul, was removed from his office. For how could it seem credible that he, who did not permit a woman even to learn in a formal manner, would grant to a female the power of teaching and baptizing? "Let them be silent," he says, "and at home consult their own husbands." 35

Augustine tacitly acknowledges that Perpetua's visions of Dinocrates are unorthodox in that he finds it necessary to provide what is clearly a rationalization for this event. He claims that seven-year-old Dinocrates was doubtless a Christian, and old enough to have committed venial sin after he was baptized and before his death. ${ }^{36}$ Yet Augustine surely realized that Dinocrates died well before Perpetua converted to Christianity and that it was doubtful he had taken it upon himself at a very early age to convert and be baptized.

Both Iphigeneia and Perpetua reject earthly authorities and traditional family loyalties as they not only accept their inevitable death but, in fact, choose it, even welcome it. And both the Greek tragedian and the Christian redactor are apparently willing to 
overlook this invitation to anarchy in favor of allowing these women to play out their heroic dramas.

At the moment of deciding to "come forth from the house," Iphigeneia, as she is portrayed by Euripides, takes control of her situation and makes it clear to those around her that she is in charge. In the process she inverts not only the accepted authority relationships but also the conventions governing male and female personality traits. She bluntly, and with a hint of disdain, informs Achilles that he must not try to save her (141620). She outlines to her distraught mother the behavior she expects of her after the sacrifice, "Not a single strand of hair must be cut for me./ No black clothes of mourning will be worn. .. ." (1437-38). And as she proceeds to the altar, she issues "orders" to the Greek army, "Throughout / The Greek camp I would like silence, pure silence" (1467-68). Iphigeneia's parents naturally anguish over her pending sacrifice, but Iphigeneia's calm acceptance of her fate places her in the parental role in relationship to Agamemnon and Clytemnestra's fretting and weeping. Initially Agamemnon considers risking the wrath of his army by reneging on his promise to Artemis and is distraught by the realization of what his agreeing to Artemis's demands means. Clytemnestra tries to prevent the sacrifice throughout the play. As Iphigeneia leaves her mother to go to Artemis's altar, Clytemnestra attempts to stop her. "You're going now?. . Leaving your mother?" Clytemnestra asks Iphigeneia. Then she begs her, "Stop! Don't go! I can't be left alone!" (1467). After the sacrifice, a messenger reports to Clytemnestra that Agamemnon has been observed crying as Iphigeneia approached the sacrificial spot. "When Agamemnon saw his daughter walking to her death / His groans began. He twisted his face away / Let the tears flow, and hid his eyes with his cloak" (1547-1550).

In his scenes with Iphigeneia and Clytemnestra, Achilles becomes vain, selfcentered, pretentious, and immature in contrast to Iphigeneia's brave stoicism. While Clytemnestra searches desperately for a way to save her daughter's life, Achilles worries 
about the appearance of things. When Clytemnestra laments the impending death of her child by saying "They're going to kill my child," Achilles, couching his own fine qualities in hypocritical humility, lays out his credentials:

I feel exalted, as if my spirit were soaring

High above the earth. I was taught to accept

Misfortune calmly, and in success to curb my joy.

That kind of man has his life worked out, he views

The world with a level gaze. (918-928)

When Clytemnestra offers to bring Iphigeneia to kneel at his feet in gratitude for his offer to save her life, Achilles demurs, not because he possesses any unmanly humility but because he again manifests a womanly concern about superficial appearances and the possibility of "gossip":

No, my lady, not out here--she might be seen.

Don't bring her out, don't subject me

To the cheap jibes of the fools around us.

This army is a rabble, an idle mob on holiday,

And it adores salacious gossip, words that knife you in the back.

Then, with his version of graciousness, he tells Clytemnestra, "Certainly, if you want to, come / And kneel at my feet ... " (998-1003). Later, Achilles promises to "Fight an army singlehanded" in order to save Iphigeneia's life (1358). However, when Iphigeneia announces her decision to die for Greece Achilles, perhaps to prevent her from becoming a greater hero than he is, declares that he must have her as his wife:

... When I look

Into your soul I feel such a need and love for you,

More than I ever felt before. You are a true

Princess .. .No! Look, I want you to live.

I must take you home with me. (1409-1415)

Iphigeneia responds, calling Achilles "stranger," and telling him, "Enough battles are being fought / For Helen's sake . . . . Kill no one / For me. Let me save Greece” (1217-40). But Achilles, while he admits, "Your courage puts me to shame / The finest soldier here," suggests fatuously, "All the same, you may change your mind" (1423). Juxtaposed against Clytemnestra's genuine and natural maternal anguish and Iphigeneia's cool logic, 
Achilles's claim to be "the finest soldier here" sound a bit hollow. In Euripides's telling of it, it is Iphigeneia's wisdom and steadfastness that prevent the chaos that would follow if the whims of the flighty male warriors were not tempered by the the intelligent decisiveness of the female hero.

Perpetua's father, like the men in Iphigeneia at Aulis, is depicted in The Passion as emotional and irrational. In Perpetua's description of the martyrs' public hearing, she describes her father's efforts to assert his patriarchal authority in terms that make him look pathetic in contrast to her noble dignity. She tells her reader that he,"would draw [her] from the step" demanding that she make the sacrifice to the gods for the welfare of her son and the honor of her family. The proconsul, witnessing her father's anguished efforts to change his daughter's mind, echoes her father's private words: "Spare thy father's grey hairs; spare the infancy of the boy. Make sacrifice for the Emperors' properity." After Perpetua refuses with a blunt, "I will not sacrifice," her father continues to try to "cast down [her] faith." As a result, "Hilarianus [the proconsul] orders him thrown to the ground and smitten with a rod" $(6 ., 28)$.

While Perpetua mentions her father more often than she mentions any other member of her family, over the course of her narrative she redefines their relationship and rewrites their roles, consistently depicting herself as rational and composed and depicting her father as irrational and weak. Perpetua describes her father's pleas to her as "diabolical," his age as "pathetic old age," and his public humiliation. In her text, she is careful to demonstrate, through her description of her behavior, her assimilation of masculine stoicism and reason into her definition of herself thus avoiding the bumptious pomposity of Achilles's verbal declarations of his heroic character.

Perpetua continues to reinforce this role reversal in each subsequent encounter with her father. She twice portrays him literally at her feet in a position of absolute submission, inverting the configuration of the pleading gestures Iphigeneia uses with Agamemnon. In 
her narrative, Perpetua remains calm, brave, logical, and unemotional in the face of certain death while she describes her father as crying, irrational, and distraught. At one point, he begs, "Do not abandon me to be the reproach of men," as he "kiss[ed her] hands and [threw] himself down before [her]." This inversion of traditional gender behavior can be seen again in Perpetua's last interaction with her father: "Now when the day of the games drew near, there came in my father unto me, spent with weariness, and began to pluck out his beard and throw it on the ground and to fall upon his face cursing his years and saying such words as might move all creation" $(9,30)$. Here there may be an explicit reference to Greek theater. Tearing hair from the beard was an accepted gesture of grief. Both the redactor, as he describes Perpetua's behavior just before and during her ordeal in the arena, and Saturus, in his vision that he describes in his own words, support Perpetua's description of herself as a leader within her prison community. Both contributors to The Passion sustain Perpetua's establishment of the Euripidean tradition in which the female sacrificial victim is given a public voice and the opportunity to play out her role in the public arena. In Sarturus's vision, he and Perpetua encounter leaders of the Carthaginian Christian community who are disagreeing with each other. Whereas a man such as Saturus usually would have talked to the bishop and the presbyter about their dispute while Perpetua silently listened, Saturus, in his vision, sees Perpetua participating in the discussion and talking to the other men in Greek $(13,34)$.

Perpetua, as depicted by the redactor, also assumes authority among her fellow prisoners that usually would be the prerogative of Saturus, the Christian prisoners' elder, or another older male member of the group. The redactor, instead, describes Perpetua as negotiating with the military tribune for better treatment. As a result of rumors that the Christians would use magic to escape from prison, the prisoners are place in a more secure area and receive harsher treatment. The redactor describes Perpetua's boldness: 
When they were being more cruelly handled by the tribune because through advice of certain most despicable men he feared lest by magic charms they might be withdrawn secretly from the prisonhouse, Perpetua answered him to his face: Why dost thou not suffer us to take some comfort, seeing we are victims most noble, namely Caesar's, and on his feast day we are to fight? Or is it not thy glory that we should be taken out thither fatter of flesh? The tribune trembled and blushed, and gave order they should be more gently handled, granting that her brothers and the rest should come in and rest with them. Also the adjutant of the prison now believed. (16., 36-37)

This is not a humble Christian arguing with a Roman tribune. Rather, it is an aristocratic Roman woman using the rhetoric of public discourse to achieve her ends. She demonstrates that it is in the tribune's own interest to provide her with what she wants She also successfully argues with the military tribune over their attire in the amphitheater:

And when they had been brought to the gate and were being compelled to put on, the men the dress of the priests of Saturn, the women the dress of the priestesses of Ceres, the noble Perpetua remained like firmness to the end, and would not. For, she said: For this cause came we willingly unto this, that our liberty might not be obscured. For this cause have we devoted our lives, that we might do no such this as thing; this we agreed with you. Injustice acknowledged justice; the tribune suffered that they should be brought forth as they were, without more ado. $(18 ., 38)$

In these situations, Perpetua is described as asserting herself as would an aristocratic man in a similar situation. Assuming that the redactor is following Perpetua's instructions, as he claims to be doing, Perpetua also demonstrates her awareness of how readers read by allowing the redactor to describe these incidents. Had she described them, her calm stoic persona would be read as arrogance.

As he metamorphoses Iphigeneia from a frightened girl into a courageous hero, Euripides carefully prepares her for her role as a human sacrifice. As seen in Iphigeneia and other female Euripidean sacrificial heroes, the criteria for the appropriate victim are similar to those for perfect animal blood sacrifice. 37 The female sacrificial victim must be virginal, at least adolescent, and not too old or unattractive to be a desirable bride. As Nicole Loraux explains in Tragic Ways of Killing a Woman, "Virgins must die by execution. For that is indeed the rule--or what passes for a rule in the world of tragedy: a sacrifice is made, usually with bloodshed, and the victim is a young girl.'38 Like Iphigeneia, a sacrificial 
animal had to be perfect and a willing victim. Lane Fox describes the care taken in choosing an animal for ritual blood sacrifice in the late fourth century B.C.: "The divisions of the town's citizen body each presented a well-groomed ox on parade in the marketplace." The magistrates then chose "the prize animal for their gods." All the oxen "were driven back onto the agora, and if their chosen ox "bows his head, let him be sacrificed to the goddess." Robin Lane Fox, in Pagans and Christians, also explains that sometimes the "assent" of the animal was less than voluntary: "The animal was sprinkled with water, which caused it to shiver and thus signify its assent to the act."39

While it cannot be said that either Iphigeneia or Perpetua was coerced in such an obvious way, their assent was given in the face of inevitability. Nevertheless, they did not meekly accept their fate but boldly and even joyously welcomed it. Iphigeneia says when she enters the sacrificial grove:

Father, here I am. Look. I give my body away.

Take it, take it for our country's sake,

For the sake of all Greece. I give it willingly

Lead me to the altar of the goddess, since we must

Obey the command she sends....

One thing more.

No one must touch me,

I shall let you cut, I shall not cry,

And in my heart will be joy. $(1550-60)$

Likewise, Perpetua and her companions are described by the redactor as "march[ing] from prison to the amphitheater joyfully as though they were going to heaven." And he speculates about Perpetua, "Perchance so great a woman could not else have been slain (being feared of the unclean spirit) had she not herself so willed it" $(21 ., 42)$.

Undoubtedly, the most difficult characteristic of the female Greek sacrifice for Perpetua to achieve is the prerequisite virginity of the desirable bride. Agamemnon, as he agonizes over the decision he must make says, "Oh, my poor / Innocent child! ... Why innocent? She'll soon / Be wed. To death! . . . And when Iphigeneia is being prepared for the sacrifice, Achilles says, "Artemis,. . . Receive this sacrifice which we, the Greek 
army $/$ And its general Agamemnon, jointly offer up to you./ The blood is pure, it comes from a virgin throat" (1570-74). Perpetua, unlike Iphigeneia, enters her drama as a newly married woman "nobly born, reared in a liberal manner, wedded honourably ... [with a ] child at the breast" $(2 ., 23)$. As she writes her text, Perpetua recreates herself as a virgin by eliminating any mention of her husband, focusing heavily on her relationship with her father, whose agony mirrors that of Agamemnon and Clytemnestra for the youthful Iphigeneia, and eventually sending her baby off, presumably to be raised by her parents. In an early episode in her story, Perpetua describes herself as "tormented there [in prison] by care for the child." However, after her sentencing, she asks that her father bring the baby to her. "... But my father would not give him. And as God willed, neither is he fain to be suckled any more, nor did I take fever, that I might not be tormented by care for the child and by the pain of my breasts" $(6 ., 28)$. As the redactor takes over the narrative, he reinforces the reading of Perpetua as a virgin by juxtaposing Felicity, Perpetua's slave who gave birth in prison two days before the martyrs entered the arena, against Perpetua when he describes them being brought nude into the arena (20., 39). "The people shuddered, seeing one a tender young girl (emphasis mine), the other her breasts yet dropping from her late childbearing" (20., 39-40). Both Iphigeneia and Perpetua are described as brides, with death by the sword as their wedding ceremony. The chorus in Iphigeneia at Aulis explains, "You go from your mother to your wedding, / All in one day,/ Given away to save the men of the race of Inachus" (1089-90). As she is going to the arena, Perpetua is described by the redactor as going "along with shining countenance and calm step, as the beloved of God, as a wife of Christ" $(18,2)$. This rhetorical revision results in the establishment of two of the conventions of female sacred biography as outlined by Heffernan: the "freedom from the Pauline notion of sexual indebtedness" and "the change from virgin, wife, or widow to the Bride of Christ."40 
Perpetua stands at the beginning of a line of Christian women writers and must turn to pagan sources for her models. Perpetua's concept of the ideal Christian martyr more closely resembles a Greek tragic hero than an orthodox Judeo-Christian martyr at the time. Lane Fox explains the development of the orthodox model.

In Jewish history, martyrs had died for the law and its observance. Among Christians, martyrs died because they refused to honour the pagan gods. Before them lay the example and promises of Jesus, who had gone passively to his death, refusing to explain to his judges the truth, in his view, of his mission. The element of personal surrender was not lost on some of his heirs. ${ }^{41}$

The only Christian martyrs possibly familiar to Perpetua were a group from Scillium executed in the year 200 in Carthage. Robeck speculates that "Christians at Carthage would ... have kept this memory alive among them and done so as a source of encouragement and exhortation for new converts."42 Little is known about the conduct of these martyrs.

Models for martyrs' behavior were developing at this time in other geographic locations. St. Stephen, according to W.H. C. Frend, was "the perfect martyr in the tradition of the second-century Church." Stephen died as a witness to the truth of Christ; he imitates Christ by praying for the forgiveness of his enemies; and God provides him with a vision of the next world in his final moments. ${ }^{43}$ Frend, writing about the Martyrs of Lyons, observes that the "victims' constancy and steadfast devotion [under unspeakable torture] were truly amazing." 44 That early Christian martyrs had feelings of humility and unworthiness, while at the same time relishing the opportunity to die for Christ, is demonstrated in some of their use of forceful metaphors. For example, St. Ignatius of Antioch wrote to the Roman Christians in ca. 110 A.D. from his prison cell:

I am writing to all the Churches and I enjoin all, that I am dying willingly for God's sake, if only you do not prevent it. I beg of you, do not do me an untimely kindness. Allow me to be eaten by the beasts, which are my way of reaching to God. I am God's wheat, and I am to be ground by the teeth of wild beasts, so that I may become the pure bread of Christ. [emphasis mine] ${ }^{45}$ 
Martyrs' stories written prior to Perpetua's Passion were written by men such as St. Ignatius. Even when they described female martyrs, the pattern evident in St. Ignatius's response to his martyrdom guides the narrative. The best known female martyr prior to Perpetua was Blandina, who was martyred in Lyon in 177. After stoically exemplifying Christ by passively enduring days of grisly torture along with her fellow convert-prisoners, Blandina was the last to succumb. Unlike Perpetua, Blandina was a slave, and her story is told by a male writer who creates in his narrative a woman who is an icon for the humble passive victim. She is described as proving "that the things that men think cheap, ugly and contemptuous are deemed worthy of the glory before God."46 After one ordeal, she is lauded by the narrator: "Tiny, weak, and insignificant as she was she would give inspiration to her brothers, for she had put on Christ."\$47

Had Perpetua known about Blandina, if Perpetua's depiction of herself in The Passion is any indication, she would have admired Blandina's heroic endurance but rejected the idea of being described as "cheap, ugly, [and] contemptuous." Instead, Perpetua, in part by authoring her own script, presents the image of a confident, assertive, active martyr who is anything but "tiny, weak, and insignificant."

Perpetua did, however, apparently understand Tertullian's statement, in the Apology, whether or not she was familiar with the work, that "the blood of martyrs is the seed of Christians!"48 And, as Tertullian himself explains when he refers to Perpetua in The Soul (208 A.D.), while other Christians' souls are "detained in Hades," "Perpetua, that most heroic martyr, on the day of her passion, in a vision of paradise, saw only martyrs there." And, he adds, "The only key to paradise is your blood."49

Although Perpetua failed to manifest the Christian ideal of passive humility in her description of her own martyrdom, she insured forever the right of female saints and holy women to have prophetic visions, to be heard in their own words, to assume authority, and to intercede on a sinner's behalf with the Almighty. And, thanks to her confident 
assertions about her visions, Tertullian was able to reassure his persecuted congregation that martyrs go to heaven.

The possibility that Perpetua modeled her martyrdom on Euripides's portrayal of Iphigeneia rather than on the passive imitatio Christi does not mean that Perpetua saw her martyrdom as mere theatrics. Perpetua converted to the Christian religion shortly before her arrest, as a catechumen was still receiving instruction in the faith. Her baptism in prison, possibly performed before she finished her instruction, attests that she and her fellow Christians knew they might be executed. The awesome horror of her situation should not be minimized, and the depth and sincerity of her faith must be acknowledged. By converting to the Christian religion, Perpetua knowingly defied the law. She also knew that accepting baptism and maintaining her faith meant public humiliation and a gruesome death in the arena.

As a Roman aristocrat, Perpetua was unique among her fellow prisoners, two of whom were her slaves. She was well-educated and accustomed to deferring only to men and older women in her elite social class. Yet, even though she was a daughter, wife, and new mother, she rejected both her pagan family and her pagan community in favor of a family and community of devout Christians. Whether Perpetua anticipated the possibility of being arrested for having converted to Christianity, for her, facing death in a hot, dark prison where she was crowded together with other prisoners, committed to her new religion and, as a result, alienated herself from her culture and her pagan family, mirrored both her pagan and Christian ideas of hell. Her efforts not only to endure this situation but to endure it with the dignity appropriate to her upbringing and in a way that demonstrated her genuine belief in her new religion enabled her to dramatize her experience in a compelling document..

The metaphors most readily available to Perpetua for defining and interpreting her situation were those of the female Greek tragic hero familiar to her from her school 
exercises. As these metaphors fused with her partial understanding of Christian martyrdom, she developed a text that blended both elements in a way that was acceptable to the male readers who defined her as an exemplary female Christian martyr. And because she knew Iphigeneia through the text of Euripides's play as well as through public performance, Perpetua, perhaps realizing that she, like Iphigeneia, could be remembered, decided to write her own version of her experience. But as the metaphors and patterns from Iphigeneia at Aulis enter into Perpetua's narrative, a new genre emerges; one that is both Christian and pagan, yet violating conventions and traditions of both cultures. As a true synthesis, The Passion subverts both its sources in the process of creating something new. As a result, at the center of female Christian hagiography is a larger-than-life Greek paradigm. In stories by and about the women who follow Perpetua as martyrs, holy women, mystics, and authors, even the requisite humility topos becomes a hero's badge of honor.

In spite of her unconventional stance, Perpetua's contemporaries, including the redactor, Tertullian, and, in the years immediately following her death, the Church fathers, including Augustine, not only saw something admirable in Perpetua's text, but something that made it exemplary. This reading of the Passion seems inconsistent given the JudeoChristian marginalization of women based on the doctrinal interpretation of Eve's role in the fall. As Zeph Stewart explains in his essay, "Greek Crowns and Christian Martyr," Perpetua's unorthodox heroics may have served a pragmatic purpose in the early church:

Why did the Christians develop and cherish these pagan terms? It was a part, surely, of the crucially important problem for Christianity, which emerged especially in the second century, of expressing its life and beliefs in terms that would be understandable and acceptable to the Greek and Roman world into which it had moved. Especially themes and attitudes which were familiar to Jews and had an exclusively Jewish origin in earliest Christianity now needed to be explained or modified for a new audience and for a membership that was pouring in from a different background. These were the circumstances in which Justin and Clement began an accommodation to Greek philosophy. 50 
Whether or not the redactor recognizes the value of Perpetua's synthesis, he extends the tragic female hero metaphor throughout his account of Perpetua's torture and death. On the other hand, taken at face value, the redactor's statement that he or she was framing the narrative according to Perpetua's instructions indicates that, whether Perpetua realized the usefulness of this synthesis, it was nevertheless important to her that her martyrdom portray her as a noble heroic character in terms of Greek tragedy. Perpetua enhances her desired image by leaving it to the redactor to call the reader's attention to her admirable behavior and to sing her praises. Aware of pagan strictures against eulogizing women, much less women eulogizing themselves, with a nod to Christian humility, she deftly avoids appearing unacceptably brazen and irreverent.

Surely Tertullian and Augustine realized that Perpetua's text also lacked key tropes of martyrdom as exemplified by St. Ignatius and the martyrs of Lyons. Perpetua herself mentions Christ only once in her narrative although she asserts several times that she is a Christian. And while martyrs who died before Perpetua appear in her visions of heaven, Christ is never identified as present. Just as the redactor reinforces Perpetua's virginal qualities and heroic assertiveness, he also brings Christ into the framing elements of the text and quotes appropriate phrases from Scripture.

As she creates her text, Perpetua carefully chooses the incidents and the details she included. While she could not change the outcome of her situation, she took advantage of every opportunity to control the meaning of the events, the way her experience would be "read," and, in so doing, she made sure it would be read. While she may not tell her readers exactly what happened, she tells them the truth about how a noble and sincere Christian faces persecution, torture, and death.

There is an elegant simplicity in Perpetua's faith as she expresses it. Perpetua was a new member of a new religion unpopular with her pagan culture. Several sources document the pagan disapproval of the Christian converts' callous treatment of their 
families and the threat this rebellion poses to the stability of the social structure. Perpetua's text is one of the few that provide a picture, although a stoic one, of the pain converts may have experienced when severing relations with family and friends.

While Euripides' play is four times the length of Perpetua's Passion, including the redactor's frame, the Passion uses brevity to intensify the drama inherent in Perpetua's experience. Perpetua's agenda is simple. She assumes the male prerogative of writing her story in order to make sure that her experience is remembered the way she wants it to be remembered. The tension in her encounters with her father and the detailed iconography of her visions are heightened by her crisp straightforward prose. Auerbach may be accurate in his assessment of Perpetua's Latin when compared by a "specialist" to the careful composition of classical scholars:

There is no rhetorical art in Perpetua's narrative. The careful education she had received is hardly reflected in her style. Her vocabulary is limited; her sentence structure is clumsy, the connectives (frequent use of tunc) are not always clear. A specialist cannot help noting the many vulgarisms (such as mittit se for ruit) and typically Christian locutions (such as refrigerare). The language in general is brittle, quite unliterary, naive, almost childlike. ${ }^{51}$

Nevertheless, even he admits that she is "expressive." However, Auerbach's reading of Perpetua's narrative eliminates any consideration of Perpetua as an artist who not only told her story effectively but also told it with invention and style. Even in various translations, her voice and personality are tangible. And, as a woman writer, she was astute enough to realize that those segments of the narrative that sing her praises as a Christian hero had to be in a voice other than her own. Whether or not the redactor was following Perpetua's instructions, he or she ably completed Perpetua's agenda. However, while Perpetua's model, Iphigeneia at Aulis, is considered a masterpiece by many scholars, Perpetua's narrative, if considered at all, is discussed primarily because its date and author make it a unique document. 


\section{ENDNOTES}

1. G. E. M. de Ste. Croix, "Why Were the Early Christians Persecuted?," Past and Present 26 (November 1963), 6-38. This well-known Marxist historian claims that all early Christians were arrested simply because they were Christian. However, Paul Keresztes, Imperial Rome and the Christians: from the Severi to Constantine the Great, vol. 2 (Lanham, Md.: University Press of America, 1989), 7, adds that "the government's campaign was directed against Christian propaganda activities," and he observes that , according to the reports, "the majority of the martyrs were catechumens and neophytes."

2. No contemporary manuscript of The Passion survives. Dronke writes that "the earliest extant MS is ca. 900" (Dronke, Medieval Women Writers, note 3, 282). However, contemporary references to The Passion survive, for example, Tertullian, "The Soul," in The Faith of the Early Fathers: A Source-Book of Theological and Historical Passages from the Christian Writings of the Pre-Nicene and Nicene Eras, translated by W. A. Jurgens, 143-44 (Collegeville: The Liturgical Press, 1970), 144. Some scholars have speculated that Tertullian himself is the redactor of The Passion. However, recent computer analysis indicates that Tertullian is not the redactor.

3. Thomas J. Heffernan, Sacred Biography: Saints and Their Biographers in the Middle Ages (New York: Oxford University Press, 1992), 185-86. This book has been particularly helpful to this study, especially chapter 5 : "The Passion of Saints Perpetua and Felicitas and the Imitatio Christi," 185-230.

\section{Heffernan, Sacred Biography, 185-86.}

5. Heffernan, Sacred Biography, 188.

6. Heffeman, Sacred Biography, 17. Heffernan's observations on the reasons for literary scholars, and historians' neglect of Saints lives can also be applied to the genre of medieval chronicles.

7. Thomas de Cantimpre, "The Life of Christina of St Trond, Called Christina Mirabilis," translated by Margot King, in Medieval Women's Visionary Literature, edited by Elizabeth Alvilda Petroff, 184-89 (New York: Oxford University Press, 1986). For Angela of Foligno, see "Blessed Angela of Foligno: From the Liber de Vere Fidelium Experientia," edited and translated by Elizabeth Alvilda Petroff, in Medieval Women's Visionary Literature, 254-63 (New York: Oxford University Press, 1986), 256.

8. Tertullian, "The Soul," [208 A.D.] in The Faith of the Early Fathers, 144.

9. For an introduction to the cult of the martyrs and some inscriptions indicating popular esteem, see Orazio Marucchi, Christian Epigraphy (Chicago: Ares Press, 1974), 157. For inscriptions dedicated specifically to Perpetua, see Emest Diehl, Inscriptiones Latinae Christianae Veterae I \& II, (Berlin: Weidmann, 1961), Corpus Inscriptionum Latinarum [hereafter referred to as CIL] CIL 8.457; (Diehl, 3138:, 142 ); Perpetua requiebit in pace su die iou/Apriles ind. I./ bixit anis cf. CIL8.25 057; (Diehl 2040a-41, 403); CIL 11.293 (Diehl 1959a, 384); CIL 11.256 (Diehl 1962 c, 382).

10. These Sermons, No. 280, 281, and 282, are included in Shewring, The Passion, 45-51. They are currently being translated by Edmund Hill, O.P., for the series 
The Works of Saint Augustine: A Translation for the 21st Century (Brooklyn: New City Press).

11. Shewring, The Passion, "Sermon 280," 45.

12. For the information regarding Perpetua's early popularity, I am indebted to Patricia Wilson-Kastner et al., A Lost Tradition: Women Writers of The Early Church (Washington, D.C.: United Press of America, 1981), 17. Heffernan in Sacred Biography, 193, also surveys early evidence of Perpetua's popularity.

13. Heffernan, Sacred Biography, 186.

14. Auerbach in Literary Language, 60 , Dronke in Women Writers, 1 , and Robin Lane Fox in Pagans and Christians (New York: Alfred A. Knopf Inc., 1989), 401, assert, without reservation that Perpetua and Saturus's accounts are authentic. Indeed, WilsonKastner in A Lost Tradition writes, "The majority of historians who have seriously studied the document agree that Perpetua's and Saturus' accounts are authentic self-descriptions since they differ markedly from each other's and the redactor's style and use of language" 13. Despite overwhelming scholarly opinion, we cannot obtain absolute proof of authorship regarding The Passion.

15. Musonius Rufus, "The Study Of Philosophy," in Women's Life in Greece and Rome: A source Book in Translation, edited and translated by Mary R. Lefkowitz and Maureen B. Fant, 50-51, 2nd ed. (Baltimore: Johns Hopkins Press, 1992), 50.

Press, 1989), 219.

16. William V. Harris, Ancient Literacy (Cambridge, Mass.: Harvard University

17. Sarah B. Pomeroy, "Women in Roman Egypt," Reflections of Women in Antiquity edited by Helene P. Foley, 303-22 (New York: Gordon and Breach Science Publishers, 1981), 313.

18. Pomeroy, "Women in Roman Egypt," 314.

19. Harris, Ancient Literacy, 126.

20. Pomeroy, "Women In Roman Egypt," 314.

21. H. I. Marrou, A History of Education in Antiquity, translated by George Lamb (New York: Sheed and Ward, Inc., 1956), 258.

22. Donald Lemen Clark: Rhetoric in Greco-Roman Education (New York: Columbia University Press, 1981), 149, 200-01.

23. Aristotle, Poetics, translated by S.H. Butcher, Critical Theory Since Plato, edited by Hazard Adams, 48-66 (New York: Harcourt Brace Jovanovich, Inc., 1971), 50.

24. Babuts, The Dynamics of the Metaphoric Field, 113.

25. Euripides, Iphigeneia at Aulis, translated and commentary by Kenneth Cavander (Englewood: Prentice-Hall, Inc., 1973). All references to this play are taken 
from this edition of Euripides's play. All citations to the play are as line numbers parenthetically within the text.

26. Sophocles, Ajax, translated by F. Storr (Cambridge, Mass.: Harvard University Press, 1961), 31.

27. Aristotle, Politics, translated by Ernest Barker (Oxford: Clarendon Press, 1954), 36.

28. Thucydides, History of the Peloponnesian War, translated by Rex Warner, (London: Penquin Books Inc, 1972), 151.

29. Quoted in Sarah B. Pomeroy, Goddesses, Whores, Wives, and Slaves: Women in Classical Antiquity, (New York: Schocken Books, 1975), 177.

30. All the Biblical references are from The New Oxford Annotated Bible with the Apocrypha, Revised Standard Verson, edited by Herbert G. May and Bruce M. Metzger (New York: Oxford University Press, 1977), 1. Tim. 2: 11-15. All further Biblical citations will be noted parenthetically within the text.

Of all the New Testament Books attributed to Paul, the two Timothy Books are the least likely to have been written by him. However, scholars overwhelmingly agree that the ideas expressed in these Books are in accord with the ideas that Paul expresses in the other Books that he is more likely to have authored.

31. Robeck, Prophecy in Carthage, 34.

32. Robeck, Prophecy in Carthage, 239.

33. Heffernan, Sacred Biography 185.

34. See Tertullian, "Baptism," In The Faith of the Early Fathers: A Source-Book of Theological and Historical Passages from the Christian Writings of the Pre-Nicene and Nicene Eras, translated by W. A. Jergens, 126-29 (Collegeville: The Liturgical Press, 1970), 128. The exception to this position occurs, of course, when a person is likely to die before a priest can be located. For example, mid-wives could baptize babies if it seemed unlikely that the baby would survive long enough for a priest to baptize it.

35. Tertullian, "Baptism," 128.

36. St. Augustine, De Anima, I. 10, cited by Shewring in the "Introduction" to The Passion of SS. Perpetua and Felicity, Xv.

37. John Wilkins, "The State and the Individual: Euripides' Plays of Voluntary Self-Sacrifice," Euripides, Women, and Sexuality, edited by Anton Powell, 177-94 (New York: Routledge, Inc., 1990), 178.

38. Nicole Loraux, Tragic Ways of Killing a Woman, translated by Anthony Forser (Cambridge, Mass.: Harvard University Press, 1987), 32.

39. Lane Fox, Pagans and Christians, 69-70. 
40. Heffernan, Sacred Biography, 185.

41. Lane Fox, Pagans and Christians, 437-38.

42. Robeck,. Prophecy in Carthage, 22.

43. W.H.C. Frend, Martyrdom and Persecution in the Early Church: A Study of a Conflict from the Maccabees to Donatus (Oxford: Alden Press, 1965), 14; Acts 7:52; Acts 7:60; Acts 7:56.

44. Frend, Martyrdom and Persecution, 13.

45. St. Ignatius of Antioch, "Letter to the Romans," The Faith of the Early Fathers: A Source-Book of Theological and Historical Passages from the Christian Writings of the Pre-Nicene and Nicene Eras, translated by W. A. Jurgens, 21-22 (Collegeville: The Liturgical Press, 1970), 21-22.

46. The Martyrs of Lyons," in The Acts of the Christian Martyrs, edited and translated by Herbert Musurillo, 62-85 (Oxford: Clarendon Press, 1972), 67.

47. Musurillo, "The Martyrs of Lyons," 75.

48. Tertullian, Apology, in The Faith of the Early Fathers: A Source-Book of Theological and Historical Passages from the Christian Writings of the Pre-Nicene and Nicene Eras, translated by W. A. Jurgens, 112-18 (Collegeville: The Liturgical Press, 1970), 116.

49. Tertullian, "The Soul," in The Faith of the Early Fathers: A Source-Book of Theological and Historical Passages from the Christian Writings of the Pre-Nicene and Nicene Eras, translated by W. A. Jurgens, 143-44 (Collegeville: The Liturgical Press, 1970), 144.

50. Zeph Stewart, "Greek Crowns and Christian Martyrs," in Memorial AndreJean Festugiere: antiquite paienne et chretiaenne, edited by E. Lucches and H. D. Saffrey, 119-24 (Geneva: Patrick Cramer Publisher, 1984), 124.

51. Auerbach, Literary Language and Its Public, 63. 


\section{CHAPTER III}

\section{DIALOGUE IN SELF-DEFENSE \\ DHUODA: MILITANT MOTHER WITH A SUBVERSIVE AGENDA}

Let no one deem me a poor weak woman who sits with folded hands, but of another mould, dangerous to foes and well-disposed to friends: for they win the fairest fame who live their life like me. Euripides, Medea 800-805

Medea's accurate description of herself in this speech ironically highlights those qualities that would be points of honor if she were a man. But Medea, according to the traditional definition of women's behavior, should be a "poor weak woman who sits with folded hands," in spite of the fact that, in her opinion, she is entitled to revenge. While men who "live their life like [Medea]" might "win the fairest fame" by avenging a wrong done to them, Medea's actions make her "dangerous," not only to her "foes" but also to the very foundation of the cosmic order.

Dhuoda, a ninth-century Frankish noble woman separated from her husband and her two sons by the political upheavals that followed the death of Charlemagne, encourages the readers of her Manual to read the author as a "poor weak woman who sits with folded hands." Readers might cooperate by assuming, a priori, that her writing is the work of a dutiful wife and loving mother using what poor resources she has to communicate with her son whom she may never see again. Nonetheless, in addition to creating a text with substantial literary merit, Dhuoda saturates her Manual with information and advice for her son William. What a reader might overlook is the extent to which this advice is subversive, given William's precarious situation.

In a chapter on Dhuoda, Peter Dronke, in his effort to give her a reading that honors her efforts, provides an illustration of how the patriarchal assumptions embedded in 
reading and assessing texts prevents even the most sincere scholar from giving a woman's writing the same consideration he would give a man's writing. Dronke's assessment of the literary value of Dhuoda's manual glows with admiration for "showing us a mind and presence of such sensitive individuality." $\mathrm{He}$ compares her relationship to her contemporary writers to that of the Victorian Gerald Manley Hopkins to "the major Victorian poets."

... while some critics might wish to stress Hopkins' limitations and the more rebarbative aspects of his language, for others (including myself) the fact of overriding importance is simply that Hopkins saw and communicated so much that was beyond the ken of any 'eminent Victorian'.?

Dronke sums up his praise of Dhuoda as an author: "In short we cannot reduce Dhuoda's testament to any of the norms of style or genre current in her time, and many expectations arising from such norms will be dashed (or, I should prefer to say, surpassed)."3 His strategic use of parenthesis allows Dronke to acknowledge Dhuoda as a serious artist without insisting that scholars redefine the ninth-century canon to include her. Dronke also recognizes the subversive nature of Dhuoda's advice on Christian conduct but attributes it to her effort to "work out a way of earthly serenity and ultimate salvation through these cares, not by rejecting or minimizing them." 4 Dronke's reading reduces Dhuoda to being a mere poor weak woman left with no choice but to sit with folded hands in the midst of the political turmoil that threatens her family and the personal difficulty of her situation, helpless to do anything but try to find "earthly serenity." It apparently never occurs to Dronke that the purpose of Dhuoda's subversive advice, couched in terms of counseling her son about his Christian conduct, may, in fact, be her way to guide her son through a treacherous situation. Had Dhuoda been more explicit in her advice to William, a reader loyal to Charles the Bald would have realized that her agenda was to make sure William understood that, if the family's property or honor conflicted with his responsibility to the king, his allegiance must be with his father and against the king. Evidence has not surfaced 
to indicate whether William ever saw the Manual, but, had Dhuoda not cloaked her subversive message in the prose and poetry of a loving mother longing to be with her son to guide him as he matured into a man worthy of his station in life and a good Christian, chances are that factions loyal to Charles the Bald would have silenced Dhuoda and William's situation would have been even more perilous.

Dhuoda's Liber Manualis, is the ultimate pastiche of forms, metaphors, and rhetorical devices of writers and thinkers whose ideas and tropes are embedded in her memory by the education she received as the daughter of aristocratic parents. In addition to Scripture, this education included six centuries of writing by Christian clerics. There is often no way of determining when Dhuoda borrows knowingly and when certain dynamic patterns mesh to make meaning for her without her being fully aware of their implications.

However, Dhuoda states her agenda clearly in the paragraph introducing the opening prayer of the Manual:

Having noticed that most women in this world are able to live with and enjoy their children, but seeing myself, Dhuoda, living far away from you, my dear son William, filled with anxiety because of this, and with the desire to be of aide to you, I am sending you this little manual, written by me, for your scrutiny and education, rejoicing in the fact that, though I am absent in body, this little book will recall to your mind, as you read it, the things you are required to do for my sake. 5

Dhuoda's three main concerns are to be present in William's life in some way even though she cannot be with him in person and to aid and educate him. The prayer, an acrostic in which the first letters of each line read vertically spell out in Latin the phrase, "Dhuoda greets her dear son William. Read!' contains the essence of her concerns for William in terms of the kind of aid and education she hopes to provide for him.

Let him read this volume and turn to it again at appropriate times, heeding the sayings of the saints and obeying them in his thoughts.

Help him to reflect, with the intelligence he receives from you, how, when, and to whom he should offer his support

Endlessly, for your sake, may he pursue the four virtues, so that, keeping to them, he may accomplish anything.

Let him be generous, wise, dutiful and brave, never straying from self-control. ${ }^{7}$ 
Her first concern, as expressed in the first sentence of this part of the prayer, is William's spiritual well-being, in this world and the next. More subtle is her concern for his secular well-being expressed in the second, third, and fourth sentences of this segment of the prayer. In this prayer, Dhuoda also makes an extraordinary claim for authorship and the efficacy of her prayers on William's behalf: "No one will ever be what I am to him, unworthy though I may be, I am his mother .... I am prey to many doubts that crowd in, while I feebly attempt to intercede for him." While Dhuoda deftly manipulates the humility topos, she nevertheless claims that her position as William's mother gives her the prerogative to intercede on his behalf and to request favorable treatment from God. While it is not unusual for a mother to pray for her son, Dhuoda is asking for direct intervention by God in helping her mold William's behavior. To understand Dhuoda's anxiety about William's conduct and why she feels the need to usurp the prerogative of a cleric or priest in assuming personal responsibility for his spiritual education, it is first necessary to understand the history of the events that lead to William being held hostage in the court of Charles the Bald.

Dhuoda, a woman from a distinguished aristocratic family, married Bernard of Septimania, June 29, 824, in the palace at Aachen. Riche, in Daily Life in the World of Charlemagne, analyzes possible sources for the name Dhuoda and the names of her family mentioned in the Manual and speculates that Dhuoda's birthplace and family home is in Austrasia. However, Riché asserts, "Si nous n'avions pas conservé les manuscrits du Manuael, nous ignorerions tout de Dhuoda. Les chroniqueurs carolingiens parlent à plusieurs reprises de Bernard de Septimanie mais ne soufflent mot de son épouse."8 Therefore, what is known about Dhuoda is what she says in the Manual and what can be inferred from her historical and cultural context. In the Manual, she records the date of her wedding and the dates of the births of her two sons. The older son, William, to whom the Manual is addressed, was born November 29,826, and the second son, Bernard, was 
born March 22, 841. In November 841, when she begins the Manual, Dhuoda is living in Uzès in the south of France near Nîmes, and Riché surmises that she ended her days there sometime soon after February 843 when she finished the Manual. ${ }^{9}$

Dhuoda's husband, Bernard, was the son of Charlemagne's German cousin Saint William of Gellone. As a second cousin and godson of Charlemagne's immediate successor, Louis the Pious, Bernard supported Louis and held several positions of responsibility during his reign. In 827 , three years after his marriage to Dhuoda, Bernard assumed the post of Count of Barcelona. In this position, Bernard mounted a courageous defense of Barcelona against Visigothic rebel invasions and successfully defended the Spanish Marches. As a result, Louis the Pious named Bernard his chamberlain in 829, making him one of the most powerful men in the Carolingian kingdom. As Arthur J. Zuckerman explains, in A Jewish Princedom in Feudal France: 768-900, "In this office Bernard, while retaining his post as Count of Barcelona, exercised a decisive influence on imperial affairs.... After the Emperor, a contemporary reports, Bernard was second in the realm."10

However, after the death of his first wife, Irmengard, in 818, Louis the Pious married Judith, and when their son, Charles, later Charles the Bald, was born, she claimed a share of the kingdom for him. Louis the Pious had arranged for his eldest son by Irmengard, Lothar, to assume imperial power and for Lothar's two younger brothers to become governors of parts of the kingdom, and subordinate to Lothar. Lothar initially did not object to Louis the Pious's arranging for Charles the Bald also to assume a governorship. However, a group of powerful noblemen led by Wala objected to the inclusion of Charles the Bald in the arrangement. The hostilities between Judith and Wala's forces intensified, making it necessary for all those connected with the power structure to take sides. Bernard, as chamberlain, had been "assigned as protector of the infant Charles," and "from the start it was clear that Bernard's role and destiny would ally 
him with the young queen and her infant son."11 In the role of Chamberlain, Bernard removed the factions opposing Judith from the court and positions of power, further antagonizing them. As a result, Bernard was vilified by his enemies, often in writing. Whether or not he was the monster they depicted him , they succeeded, not only in ruining his reputation during his lifetime, but also in providing historians with ample material in support of their view. Led by Wala, the forces opposing Judith accused Bernard of adultery with the queen, lechery in general, misrule, tyranny, and even plotting the death of Louis the Pious. ${ }^{12}$

After Louis the Pious's death in 840 , Charles the Bald received Aquitaine and Septimania, territories formerly held and governed by Charlemagne's third son Pipin. Bernard allied himself with Pipin in an effort to maintain control of his family's territory. With Louis dead and the conflicts between Lothar and his brothers, the forces opposing Charles the Bald, and the Bernard-Pipin factions spawned an almost incomprehensible network of intrigue and hostile confrontations. ${ }^{13}$ In 841 Bernard, sent his eldest son, William, then sixteen, to Charles's court to pledge loyalty to Charles the Bald in return for recognition of William's rights to his Burgundian inheritance. Charles, however, determined that the best way to maintain Bernard's loyalty and to keep control the Burgundian inheritance was to keep William at court, if necessary, as a hostage.

This then is the situation that Dhuoda and Bernard found themselves in in the fall of 841 , when Dhuoda began her remarkable book. While Bernard was either negotiating, battling opposing forces, or trying to outwit scheming enemies, Dhuoda had taken up residence in Uzés, where she was relatively safe and able to borrow money to support Bernard's efforts. Before her residence in Uzés, Dhuoda was apparently with Bernard during his campaigns against the Visigoths and his tenure as Count of Barcelona.14 While many readers, taking the defamatory statements of Wala and his supporters at face value, assume Dhuoda was abandoned by Bernard, she may well have been forced to stay in Uzés 
due to her poor health: a condition she refers to often in the Manual. In March of the year Dhuoda began her Manual, her second son was born. Before he was baptized, Bernard had him taken from Uzés. Bernard's motives for removing the infant are not clear. However, Zuckerman speculates that because Bernard came from an important Jewish family, he ordered his newborn son to be brought to him in Aquitaine (presumably for "circumcision on the eighth day after his birth"). Zuckerman acknowledges, however, that "it is surprising that the "Bishop Elefant, who carried out Bernard's order, did not baptize the infant" in Uzés, before the trip..$^{15}$ Riché speculates that "Bernard voulut avoir auprès de lui son second fils et le fair élever comme il l'entendait."16 Whatever his motive, it is this action by Bernard that has given rise to the reading of Dhuoda by critics and scholars as a "Griselda."

Dronke, for example, while admiring Dhuoda's writing, describes the author as an "exemplum of Griselda, as Boccaccio, Petrarch and Chaucer were to tell it."

Dhuoda, (except for her noble origins) comes close to being a Griselda in real life. And like her legendary counterpart, she almost accepts the brutish behaviour of her husband without question and without bitterness. Indeed what she commends to her far-off son is largely what Riché calls "une religion de la paternité .... Yet it is the concealed anguish that we sense as she expounds this which makes her testimony unparalleled. ${ }^{17}$

It is possible that, by having recognized the masculine-loaded Griselda metaphor early in his reading of the Manual, Dronke was prevented from pushing his own analysis of Dhuoda's accomplishments out of pararenthesis. No reader would deny that Dhuoda had good reason to feel anguish about her situation. However, in dismissing her as a submissive, oppressed Griselda, Dronke gives the Manual a reading that overlooks the fact that, in writing her Manual, Dhuoda makes an assertive gesture that would never have occurred to the spineless Griselda portrayed by Boccaccio, Petrarch, and Chaucer. By marginalizing her as a Griselda, scholars, like Dronke, are also blinded to the genius of her 
use of the manual genre to communicate with William under perilous circumstances and to the ingenuity with which she carries out her agenda.

Her commendation of "une religion de la paternité," mentioned in Dronke's assessment of Dhuoda, is based on her sincere belief that "loyalty to the human father, to the emperor, and to a Father God" is the foundation of a stable Christian society. Pierre Riché himself explains, in his introduction to his translation of Dhuoda's Manual: "Il ne faut pas se représenter Dhuoda simplement comme une mère aimante et faible. C'est une femme qui a mis tout sa force et sa fortune ... au service du chef de la famille."18 Riché argues that Dhuoda's fierce determination to support her husband and his cause is not the result of blind subservience but, in fact, stems from her firm belief that she and her husband are partners in the same cause: to honorably procure and protect family territory, to defend the honor of the family name, and to assure the rightful assignment of secular power in the face of the chaos resulting from the battles for power and territory that ensued during and following the reign of Louis the Pious in mid-ninth-century France. When read in this light, Dhuoda's Manual reveals cautionary messages to her son and directives regarding his secular behavior. These cautions and directives are carefully encoded in her sincere instructions on the conduct of a devout and noble Christian.

As an aristocrat and a good Frankish wife and mother, Dhuoda, although marginalized in the traditional ways, benefitted from the best education available and, like most noble Frankish mothers, had considerable responsibilities, not only in the domestic arena but in a more public arena as well. Zuckerman refers to Dhuoda as Bernard's "learned wife," 19 and Riché, noting Dhuoda's unique achievement, writes, "We do not know of any other woman who wielded the pen in the ninth century." 20

Even though Dhuoda is the only known woman author of this period, most aristocratic women were well educated and were, in fact, according to Riché, responsible for their children's education. 
When a child began to outgrow his toys, his parents, particularly his mother, taught him to read the psalter, a book of elementary pious readings which could be carried in the hand. Through learning the psalter, he was familiarized with grammar, chant, and the rudiments of ecclesiastical offices .... The athletic training which young people later received threatened to erode the foundations of their intellectual training. While mothers insisted that their sons give themselves over to reading like clerks, their fathers preferred to see them learn to mount a horse, draw a bow and skillfully cast falcons .... 21

This being the case, Dhuoda's concern for William's continued education in spite of his distance from her is perfectly natural. Because the two of them had interacted as tutor and pupil for some years, Dhuoda intutitively as well as consciously knew something both about the dynamic patterns available to William and about how he learned to make meaning of a text and his situation.

Much evidence supports the claim that Dhuoda and women in similar positions received a quality education that would enable them to provide excellent training for their children. According to Riché, Charlemagne instituted an "innovative" educational program that was continued by Louis the Pious and was designed to instruct the "men and women of all his lands ... in the Christian message." Part of this program included the establishment of schools, run by the clergy, in which children learned "to read . . . psalms, chant, computate, and grammar," and, of course, Latin. ${ }^{22}$ Another part of this educational program was the establishment of the palace school at Aachen. Riché speculates, that having grown up in Austrasia, Dhuoda may have received part of her education at Aachen, where all young "people ... were put in [the] charge of instructors.' 23 To illustrate these educational activities, Riché quotes from Alcuin's poem addressed to Charlemagne, in which Alcuin describes life at court: "Supius conducts his white flock of lectors, teaching them not to misplace their accents. Idithun trains the children in sacred chant, teaching them how music is shaped in combination of feet, numbers, and measures. Then come the scribes and the doctors." 24 
While female Frankish aristocrats were well-educated women, according to Riché, they "held an inferior position in Frankish society." Nonetheless, "the noblewoman played an important role in the bosom of her family."25 While this role was based on the biblical model of wife, mother, and helpmate, "a wife was expected to be an active collaborator in her husband's enterprises."26 J. M. Wallace-Hadrill in The Frankish Church, elaborates on the responsibilities of the Frankish wife.

Married, the Frankish woman held the honour of two kindreds in her keeping: Her husband's and her father's. In this respect the wife's responsibility was the greater and the risks she ran if she dishonoured either kindred correspondingly greater. Thus burdened, she was no mere chattel. She could hold and administer land, defend herself in the courts, act as a compurgator, make donations and free her slaves if she wished. The higher her social rank the likelier it was that she would carry many other responsibilities than care for her household .... The stability of the family, its good name and the purity of its blood appeared to rest upon the woman, not the man. ${ }^{27}$

Dhuoda's awareness of these responsibilities is evident throughout the Manual, which she wrote in Latin, the language she learned as a girl growing up in the Carolingian courts. However, Latin scholars have tended to overlook essential aspects of Dhuoda's text because they found the quality of her Latin questionable. Dronke credits Pierre Riché's edition of Dhuoda's Manual with contributing "much that will make a new and adequate appreciation of Dhuoda's achievement possible." Dronke adds that "hitherto, literary judgments have been perfunctory and foolishly condescending: Wilhelm Meyer's claim that it is 'no joy to read Dhuoda' is still quoted and has never received serious critical challenge."28 While Dronke acknowledges that "her Latin is indeed unorthodox and at times incorrect, whether by classical norms or by the standards of Charlemagne's litterati," he adds that she does so "because she was urgently striving to say something in her own way, something that was truly hers'29 Dronke, however, quotes Meyer again to explain, "Dhuoda is one of a group of ninth- and tenth-century poets who ... introduce 'ancient Germanic rhythms into Latin verse." 30 Meyer's negative judgment of Dhuoda's writing originates, in part, from a reading of Dhuoda's Latin based on how it compares to elegantly 
correct classical Latin, ignoring the fact that Dhuoda's agenda may have necessitated taking a few liberties with the language or, more importantly, that she may have approached her task not only as a caring and concerned Frankish mother but also as a Carolingian artist. Marchand observes,

She loves to parade her learning by using strange words, some of which we can find in no dictionary, much in the manner of her countryman Virgil of Toulouse. . . . She loves to mix verse and prose. In fact she has done this so well that we still are not sure where the verse ends and the prose begins. 31

Peter Godman, in Poetry of the Carolingian Renaissance, claims that in spite of her unorthodox Latin, "Dhuoda displays to the full the modest but not negligible learning which she could muster, and her work is part of an experimental trend in Carolingian poetry which includes the Veronese writers of the late eighth century." 32 According to Marcelle Thiébaux, another factor that should be considered when assessing Dhuoda's skill as a writer is that, in spite of the education available to aristocrats in the Carolingian period, both the language of the court and the language of the battlefield were in flux. Thiébaux asserts that under these circumstances, Dhuoda's use of the "language of the Fathers" was "remarkable," especially in the context of a manual for her "soldier son," and that it "reflects the allusive style and the word play of her models." 33

Dhuoda, in the introduction to her Manual, emphasizes two key ideas--that the purpose of the book is to be held in the hand, portable, and available as a constant reference for the recipient and that it is to serve as a mirror for her son in which he can see both himself and his mother. The first of these ideas is strikingly similar to ideas expressed by Augustine in his Enchiridion on Faith, Hope, and Love, which was addressed to his fictional "dearest son Laurence." 34 In the fourth paragraph of the Enchiridion, Augustine describes the book as "something to have 'at hand' -- that deals with your questions," 35 and he adds, "something you could carry around, not just baggage for your bookshelf."36 Dhuoda explains to William that her "work has been directed from [her] hand," and asks 
that William "willingly grasp it in [his] own hand, and holding it . . fulfill its teachings in most worthwhile actions." ${ }^{37}$ Echoing Augustine's "baggage for your bookshelf," Dhuoda says, "Even though you own an increasing number of books, may it please you to read my little work often."38

In the prologue to her Manual, Dhuoda adds the following metaphor: "You will ... find in it a mirror, in which you may contemplate the health of your soul."39 In the sixth segment of the introduction, Dhuoda adds to the mirror metaphor, "You can gaze upon me as on an image in a mirror, and see me reading with my bodily and spiritual eyes, and praying to God concerning those obligations you are to render me."40 Dhuoda uses this popular metaphor in the first phrase to express the conventional idea of the Manual as an object in which William "may contemplate the health of [his] soul." She compares his use of the manual as mirror to the way "some women are accustomed to peer at their own faces in the mirror--so that they may cleanse away the spots of dirt."41 Her second use of the mirror metaphor is more personal in that she interprets the manual as mirror as her surrogate, serving as her physical, emotional, and spiritual presence in William's life. Pierre Riche discusses the development of the mirror-manual genre in the eighth and ninth centuries. These little books often were written by clerics and other members of the clergy to answer laypersons' questions about how to ensure their "eternal salvation" and provide "a rule of life which could bring the layman, like the clerks, to Paradise."42 Riché explains, "All of these 'mirrors' proposed, each in its own way, a similar program of education, to fit princes for the governance of the realm and to give all laymen the means of governing themselves." 43 The behavior prescribed for the layperson (usually an aristocratic man) included "conforming to rank, justice toward subordinates, generosity toward the church and the poor, ... good counsel to princes, ... respect [for] the sanctity of marriage, ... [and consecration of] the strength of their arms to the service of right and faith."'44 While the ostensible aim of this prescription is the salvation of one's soul, what 
is described is clearly behavior that augments the church's power in the secular life of the community and contributes to its stability. Although Dhuoda's use of the manual as mirror genre has an agenda similar to those written by clerics for noblemen, it is her adaptation of the form that makes Dhuoda's Manual unique. As Riché emphasizes in this introduction to his translation of the Manual:

Ce rapide rappel historique va nous permettre de montrer l'originalité du Manuel de Dhuoda. En premier lieu, il n'est pas écrit par un clerc, mais par une femme lä̈que, et cela lui donne un place unique dans la littérature latine du haut Moyen Age. D'autre part, c'est une mère qui adresse un livre d'éducation à son fils, et c'est également la seule œuvre littéraire de ce genre. ${ }^{45}$

Riché, like Dronke, however, overlooks the subversive element in Dhuoda's use of the manual. In order to give William advice that will help him negotiate the treacheries of Charles's court, Dhuoda must subvert not only any loyalty he might feel for Charles but also any opportunity for the clergy to influence William's behavior and decisions. To accomplish these ends through her text, she invests herself with the role of William's spiritual advisor.

In part, because of the personal nature of her text, but also because of the subleties in her use of language and because little is known about Dhuoda except what she reveals in her Manual, it is difficult to identify the point at which Dhuoda "comes forth from the house." Given the fact that she apparently traveled with Bernard, it would seem that her residence in Uzés is more of a return to the house. However, her decision to write her Manual, even though it is addressed only to her sons, is a decision to make a public statement that would not only enable her to be in Aachen via the Manual, but also enable her to record ideas to be read twelve hundred years after she wrote them. Dhuoda indicates in several passages--most notably in the paragraph introducing her epitaph at the end of the book where she refers to "those who will one day read this Manual"46--that she is aware of the possibility that the book will have readers other than William. 
In the third paragraph of the preface to the Manual, Dhuoda explains what prompted her to write it:

But after having resided in the aforementioned city [Uzés] for a long time at the order of my lord, with absence of your presence, rejoicing in his [success in] battle (agon), but with the desire to see both of you, I took care to write and send to you this little book, according to the poverty of my intelligence. 47

While Dhuoda is able to "rejoice" in her husband's military successes, she is lonely for both her husband and her son. Because Dhuoda herself is in failing health and both her husband and her son are in perilous situations, Dhuoda is well aware that she might never see her husband or her children again. Dhuoda determines that writing a "little book" will provide a way for her to bridge the miles and be a surrogate that William may have with him at all times. The fact that William is in the court of Charles the Bald as a hostage gives the task a more urgent focus as she explains in the last paragraph of the preface.

I have heard that your father, Bernard, has commended you into the hands of Charles the King; I admonish you to give a perfect goodwill to the accomplishment of your duties. However, as it says in the Scriptures, "Seek first the Kingdom of God in all things and the rest will follow," all that is necessary for the good of your soul and your body. ${ }^{48}$

Here the reader begins to sense her deep concern about sixteen-year-old William's ability to guard his actions and play the kind of cagey politics necessary to protect himself and advance the family's agenda. The cursory reader, assuming he or she is reading the work of a lonely and concerned mother, an assumption Dhuoda encouraged, will see nothing remakable in these sentences. Under the circumstances, Charles can hardly expect more fervent loyality than "perfect goodwill" and, although admonitions regarding the secular kingdom precede those regarding "the Kingdom of God," it is to be expected that the latter would take precedence over the former.

Riche observes that the phrase "commended you into the hands (in manus domni te commendauit)" alludes to the fact that William is not remaining in Aachen voluntarily 49 The qualifying "Tamen" [However] at the beginning of the second sentence, together with 
Riché's observation, hints at a less innocent reading of this paragraph. By adding the phrase "for the good of your soul and your body" to the last sentence, Dhuoda implies that the admonitions in the last sentence are to be considered in terms of what is best for William's secular as well as his spiritual well-being. In other words, William is to be polite and to avoid appearing hostile to the king, but he is to remember that his earthly and his spiritual loyalties lie elsewhere. Typically, the context of the Scripture quoted also contains useful allusions. The quotation above comes from Matthew 6:33 that contains Jesus's caution against undo concern for worldly things: "Therefore do not be anxious about tomorrow:, for tomorrow will be anxious for itself." However, the last line of this chapter in Matthew reads, "Let the day's own trouble be sufficient for the day" (Matt. 6: 34). Most ninth-century readers would be familiar enough with Scripture so that this context would be invoked by the line quoted in the Manual. Whether the connection between William's situation and the biblical reference is mere coincidence or whether, in fact, Dhuoda intended it as a mnemonic device to remind William of his precarious situation cannot be documented, but it is doubtful that Dhuoda would encourage William to be indifferent to his situation or to his concerns about material, secular things.

Many of Dhuoda's biblical citations echo with warnings and examples of conduct for William. When Dhuoda quotes this passage of the Bible to William: "Seek first the Kingdom of God in all things and the rest will follow," it is likely that Dhuoda is asking William to consider carefully and ask for God's help, as she asked God to help him in the opening prayer, when deciding, "How, when, and to whom he should offer his support."

In the second paragraph of the first chapter, entitled, "The Love of God," Dhuoda herself admits that her writing of the Manual is a bold step:

I ask and humbly suggest to your noble youth, as if I were present, and also to those whom you show this book that they may read it, that you might not condemn me and reproach me for the fact that I am so bold as to embark upon such a profound and perilous (agonizatrio) task: to direct to you instruction concerning 
God. To be sure, I myself do not cease to reproach myself, considering my human fragility, for I am poor, but dust and ashes. ${ }^{50}$

In this passage, Dhuoda repeats the idea that the Manual is her surrogate and reiterates her humility topos. In the third paragraph of the preface, quoted earlier, she mentions "the poverty of [her] intelligence," and in the paragraph quoted above, she refers to her "human fragility" and says, "I am poor, but dust and ashes." This refrain of humility and denegration is more than a convention in the Manual. The frequency and variety with which it is used serve to remind the reader that this is the work of a woman, and these references provide keys into what the reader expects to find in a woman's writing. Because of this convention, the reader, not looking for ingenuity, subtlety, or subterfuge, finds poor Dhuoda reaching out in anguish to her beloved son of whom she has been cruelly robbed. Chances are William, Dhuoda's pupil as well as her son, could be expected to 'read between the lines' when necessary. The others that Dhuoda anticipates reading the Manual would miss the carefully concealed directives intended only for William.

In the beginning of the Manual and throughout her text, Dhuoda emphasizes the exertion involved in writing and the necessity of William reading it painstakingly so that he understands exactly what she is saying. In the opening segment of her book, Dhuoda makes it clear that she expects the words she has written "to become flesh" in William.

What I desire is that when this work has been directed from my hand, you will willingly grasp it in your own hand, and holding it, you will fulfill its teachings in most worthwhile actions. For let it be said that this little book in the form of a handbook consists of words from me, and their actualization in you. As a certain one has said: "I have planted the seed, Apollo watered it, and God has made it grow. 51

In quoting Paul's advice to the Corinthians (1 Cor. 3:6), Dhuoda draws an analogy between herself and Paul who cannot be with the Corinthians and writes to them instead. But, just as Paul leaves his friend Apollo with the Corinthians to minister to their spiritual needs, Dhuoda sends William the Manual to "water" the seeds of faith and wisdom she has 
planted in him. Embedded in this quotation is the rest of Paul's message to the Corinthians, which he reiterates often in his letters to them: "For the wisdom of this world is folly with God. For it is written, 'He catches the wise in their craftiness"' (1 Cor. 3:19).

In the opening prayer of the Manual, Dhuoda prays for God to "bestow intelligence on him [William]" and to "let him read this volume and turn to it again at appropriate times." The last word in the acrostic is an emphatic "Read (Lege)."52 However, the most dramatic of Dhuoda's frequent references to reading occurs in Chapter IV, part one, "A Special Admonition to Correct Various Habits."

You have and will have books in which you may read [legendo], page through [uolendo], ruminate on [ruminando] , scrutinize [perscrutando], and understand [intelligendo], or even teachers to intruct you and these will furnish you with models to follow in the performance of both your duties. 53

Dhuoda makes it clear that reading is physical as well as mental and that strenuous effort is necessary in order for William to understand fully what she has written. In the remainder of this paragraph Dhuoda advises William to use a similar approach in reading human conduct and adds the concept of carefully scrutiny and judgment to the act of interpretation.

The same as the doves, drinking the water very pure, watching, so as to not be surprised by the rapacious herons and falcons, and that they may escape them, fly away with joy cheerfulness there where they think to find their true happiness; likewise, you, if you read attentively the words of the orthodox holy fathers, or if you observe often how the noble people and counselors, as I have told you, accomplish with zeal and fidelity that which pleases God and their commanding lords and if you do not forget to follow their example, you may escape not only the invisivle tricks of the malicious spirits, but also those of the visible, living enemies in this world and the traps they set. ${ }^{54}$

Dhuoda's reference to noble persons and lords is ambiguous except to point out that they are the ones pleasing God. What is striking about this passage, however, is her admonition to watchfulness. Even when they are enjoying a refreshing drink of water, the doves must be on guard. This caution is necesssary not only because the hazards of temptation and poor judgment are sent to plague man by Satan but also because mortals can also set traps for their fellow man. The act of reading, whether it is words in a book or the 
actions of others, necessitates a great effort in order to achieve complete and accurate understanding and make sound decisions based on the available information. The reference to watchful doves also echoes the words of Christ to His desciples, "Behold, I send you out as sheep in the midst of wolves; so be wise as serpents and innocent as doves" (Matt. 10:16). In Dhuoda's allusion, the presence of the birds of prey concentrates the qualities of innocence and wisdom in the image of the doves and simultaneously engages the icon of the innocent "sheep in the midst of wolves."

Dhuoda describes the act of writing, as she experiences it, as arduous. Thiébaux observes that, "Dhuoda gives the laborious effort of her authorship a word of her own invention: agonizatio (I.1.13, I.3.20), based on agon, which she uses elsewhere to refer to her husband's military combat." 55 Dhuoda's use of these words can be seen in the passages quoted above. Thiébaux also compares the strength of the adjectives Dhuoda uses to describe her effort at writing with the effort she encourages William to put into his reading: "She exhorts her reader/son to reciprocate her authorial struggle by striving with equal effort to read and understand."56

Because Dhuoda adapts the word for Bernards's combat to describe her writing, this use of language places their efforts in a tandem relationship. By using words that describe the similarly stenuous effort William must make to understand what he reads and act wisely, Dhuoda creates a sense of three people intensely concentrating all their energy in order to achieve the same goal: Bernard by fighting, Dhuoda by writing, and William by using his stay in the Court of Charles the Bald to his and his family's advantage. But the care and subtlety with which Dhuoda develops this theme elude the reader who takes at face value her statement that she is doing this as best she can given "the poverty of [her] intelligence." 57

Dhuoda's displeasure with Charles the Bald is illustrated in her dating of her manuscript. She writes that she began the Manual on November 30,841, "the second year 
after the death of the one-time Emperor Louis." She completed it on February 2, 843, "in the reign of the King to be designated by God." This dating deliberately ignores Charles's dominion over Septimania. That Dhuoda was not alone in her disdain is illustrated by Zuckerman's observation that "other documents, one from Beziers of December 842 and another, drawn in the March of Spain August 842, are both dated from the death of Louis the Pious and the ascendance of Lothar, likewise passing over King Charles."58. By dating the Manual in this manner, Dhuoda suggests that there is some question about whether Charles the Bald is the king and thus entitled to the loyalty and respect due one's monarch.

Dhuoda is aware that, at age sixteen, William may not be fully cognizant of the danger of his position much less of the importance of his conduct in terms of not jeopardizing either his inheritance or the efforts of Bernard to re-establish the family's prestige, power, and territory. Dhuoda recognizes William's youth and the hazards of naiveté and impulsiveness that go with it and seeks to protect him from mistakes: "You have completed four times four years. If you had that much, plus as much, plus the half of the half (16 plus 16 plus 4), I would speak otherwise to you."59 This awareness of William's situation seethes under the surface of many of her biblical citations. She informs him that,"in accord with the admonition of the Old Testament, "we have been commanded to bear the names of the twelve patriarchs on our forehead."60 This reference serves to remind William of his own noble lineage. In her chapter "On Receiving Counsel," Dhuoda advises William to "consider prudently what, when, to whom, or how you can show a worthy and fitting eloquence." She carefully explains,

It is written, 'Do all things with counsel, and thou shalt not repent when thou hast done.' This 'all things' does not include bad actions which destroy sane judgment, but rather higher and greater things which can lead without reprehension to the salvation of the soul and the body. ${ }^{61}$ 
Again, her advice explicitly concerns William's well-being on earth as well as his spiritual health, and she obliquely points to the possibility that there are people whose counsel should be avoided.

Riché in his discussion of her advice on confession points out that she is circumspect and, while advocating true and sincere contrition, Dhuoda recommends private confession and direct communication with God as opposed to public manifestations that might reveal information that would endanger William's life. Riche observes that, in a work defining the duties of a Christian aristocrat, "we would expect a chapter on private or public penance." But, he adds:

Nous aurions pu nous attendre à un chapitre sur la penitence publique ou privée. En fait, Dhuoda est très brève sur ce sujet et dit simplement: "Confieleur en secret . . ta confession sincère, avec des soupirs et des larmes." La confession à Dieu, le dialogue direct avec le Tout-Puissant lui parât être également un moyen pour se libérer de ses fautes. ... Dhuoda est également très discrète en ce qui concerne le sacrement de l'eucharistie. A peine trouvons-nous une phrase sur le sacrifice de la messe dans le chapitre sur les prêtres, et quelques lignes sur les messes offertes pour secourir l'âme des défunts. ${ }^{62}$

While Riche is correct that reading is a spiritual act for Dhuoda and that she believed in personal discourse with God, it is also probable that Dhuoda, recognizing William's unsafe circumstances, did not deem the confessional chambers a secure location for William to reveal his inner thoughts and indiscretions.

Another repeated theme in Dhuoda's advice to William is the carefully disguised set of allusions to Louis the Pious's rebellious sons. Couched in the form of admonitions against William's behaving in a similar fashion, this message is often implied..

Let the madness of infidelity never press from you an evil misdeed; let it never arise in your heart to be unfaithful to your lord in anything. The reputation of those who do so is hard and shameful. I do not believe that this will happen to you or to your knights; this kind of action, as people say, never appeared among your progenitors, never was, is not, never will be. 63

While her reference to "your lord" could mean King Charles, the reference to "progenitors" at the end of the passage alludes to William's family and especially to his father. 
Likewise, Dhuoda often reminds William of biblical examples of sons and fathers whose actions toward each other mirror the possibility for fractured loyalty inherent in William's situation. "You will be blessed, son, if you are taught by Him and merit being learned in His law. Certainly, Samuel and Daniel, still boys, flourishing in the strength of their youth, judged, as did their fathers, as old men."64 Samuel, as a boy, had visions in which he fortold God's judgment against the house of Eli because Eli's sons were corrupt and sinful. The reference to wicked sons usurping power and bringing the wrath of God down on their father and their country alludes to the sons of Louis the Pious and their treatment of Louis and, by extension, Bernard of Septimania and his family. Daniel, like William, was carried off to a foreign court against his will. There Daniel gained prominence for his ability to interpret dreams. His most famous feats are his miraculous survival in the fiery furnace and in the lion's den and his interpretation of the writing on the wall. Daniel's sentences to the fiery furnace and the lion's den were brought about because he refused to deny his Jewish faith and worship idols. This reference, with its allusion to William's paternal heritage, indicates what Dhuoda expects William to do if his loyalty to his father is tested. Daniel's reading of the writing on the wall occurred when the sons of a king who had usurped his power desecrated the holy vessels. Dhuoda often repeats the theme of unjust seizure of power and irreverent sons.

In her advice on conduct, "Toward the Family of Your Lord," Dhuoda asks William to "remember how David acted toward Jonathan, the son of King Saul, to the son just as to the father." 65 Jonathan was the son of Saul and the friend of David. When Saul's jealously of David's having been chosen by God to replace Saul resulted in a plot to kill David, Jonathan warned David but remained loyal to Saul in battle. He and Saul were killed. David, the victor, retrieved the remains of father and son after they were posthumously maimed by the victorious soldiers, and he reburied them in their ancestral 
tomb. Here again, Dhuoda illustrates the theme of sons and power and loyalty and gives William a model for his own behavior.

At first glance, Dhuoda insists that William's behavior manifest feudal loyalty to his lord and familial loyalty to his father, as though these were duties analogous to faith in God. That she demands this degree of loyalty from William to his father is illustrated in her discussion of William's obligation to Bernard.

I do not tire of impressing upon you, as much as I can, how much you ought to fear, love, and remain faithful in all things to Bernard, your father, both present and absent. For you have a teacher and an author full of wisdom, Solomon, who castigates you, son, and admonishes you, saying, "God has honored the father flourishing in children." . . .May the earth cover my body before [you despise your father or cause him grief], which will not happen, I am sure. Nor do I say this because I am afraid that it will happen; I just want to prevent this crime from ever entering your mind, for we have heard that such things have been committed by others, not like you .... So I admonish you, most beloved son William, that first you love God as you have it written down above; after that love, fear, and cherish your father, know that your status in life comes from him. 66

In contrast, however, Dhuoda commands William to serve Charles the Bald "with great intensity, as to both body and soul; keep in all things a pure and sure fidelity to him" since "God ... and your father, Bernard, have chosen him for you to serve." She reminds William that Charles is a "descendant of a great and noble family," the same family from which William himself is descended. This pattern is found often in the Manual. Dhuoda advises William to serve Charles and reminds the young man that the King deserves William's loyalty; in serving Charles, William is obeying his father. As in the examples of Jonathan and David, however, these explicit admonitions often harbor veiled reminders to William that he must remember who he is and that his primary obligations are to his father and his family.

While Dhuoda never demands that William "fear, love, venerate, and cherish the illustrious" Charles the Bald, in her discussion on William's duty to Charles's ancestors and relatives, Dhuoda implies that only those who achieve their station in life honestly and on the basis of merit are worthy of veneration. 
If you would be a useful servitor with your companions-in-arms at the royal and imperial court, you must fear, love, venerate, and cherish the illustrious ancestors and relatives of the King, your lord, who draw their high nobility from their ancestors or have acquired their charges thanks to marriage. In every action, seek their advantage and execute their orders faithfully, with your spirit as well as our body. ${ }^{67}$

Here she represents, through opposition, her abhorrence of disrupting legitimately established order. In one of her most notable pastiches of scripture, Dhuoda creates a lively image of how she gleans the intelligence and the skill to convey this information to William under the watchful eyes of powerful religious and secular men. By cleverly investing herself with the role of the "troublesome little puppy," she reinforces the marginalized position that enables her to communicate with her son:

Now it sometimes happens that a troublesome little puppy among the other whelps under the master's table can seize and devour the crumbs that fall (Mark 7.28; Matthew 15.27). He who has the power to elicit speech from the mouths of dumb animals (Numbers 22.28) can, according to his mercy of old, open the mouth of my spirit (Luke 24.45) and grant me understanding. He who prepares a table in the wilderness for his followers, giving them in time of need a sufficient meisure of wheat, can fulfill even my will--that of a handmaid--according to his desire. So I can jump under his table, that is to say, on the lower level of the Holy Church, and gaze from afar at the little whelps--those who are ministering to the sacred altars. Then from among the crumbs of spiritual wisdom I shall be able to gather for myself and for you, $\mathrm{O}$ William my beautiful son, some beautiful and luminous words that are worthy and appropriate. For I know that "his mercy has never failed (Lamentations 3.22).68

This mixture of humility and self-confidence is characteristic of Dhuoda's writing. Although marginalized by her patriarchal society, Dhuoda might, through sheer willpower, shrewd determination, and stubborn tenacity, steal an advantage over the more powerful clergy. Here again, Dhuoda is positioning herself in opposition to the clergy. This passage suggests that the Church, in aligning itself with Charles the Bald, is not to be trusted.

Dhuoda finds and uses the power of her marginalization. In so doing, she creates a text that is unique in the genre of the manual-mirror. Its autobiographical elements make it valuable as an illustration of significant aspects of ninth-century Carolingian life. Most 
interesting, however, is the way in which Dhuoda "comes forth from the house" in her text. While maintaining a deeply felt commitment to her son William's spiritual development and well being, she conveys to him the importance of remaining steadfastly loyal to his father, his family, and his own prestigious heritage. At the same time, she subtlely cautions him about the dangers of his situation in the court of Charles the Bald: dangers stemming from the fact that William's family, led by his father, Bernard, is embroiled in an intense conflict with Charles over property, power, and prestige. In this context, Dhuoda's "little book" is daring and ingenious. Its subversive content is hidden in the form that Dhuoda chose as a means to save her child and exert control in a dangerous situation.

As Dronke aptly observes, "Where Perpetua has left us only a brief memoir that had not been finally shaped when she went to her death, Dhuoda conceived and elaborated a work on a large scale."69 Dronke, also demonstrates, how deeply patriarchal assumptions are embedded in the act of making meaning. Because the metaphor that initially occurred to him when he read Dhuoda was the female Griselda instead of a male hero who bravely faces insurmoutable challenges, he stops short of fully realizing or, in any case, fully acknowledging the significance of Dhuoda as a Carolingian author. Likewise historians, accepting as fact the accusations against Bernard by Wala and his supporters, rather than considering the possibility that their opinions might be shaped by their agenda, have assumed that Dhuoda is writing not only from the marginalized position of a woman but also from a position as the woman abandoned by a husband who also cruelly robbed her of her sons. Literary scholars and historians alike, as readers, have overlooked the possibility that history should re-evaluate its assessment of her husband and should reconsider her Manual as a remarkable work of art. 


\section{ENDNOTES}

1. Dronke, Women Writers of the Middle Ages, 36.

2. Dronke, Women Writers of the Middle Ages, 37.

3. Dronke, Women Writers of the Middle Ages, 38.

4. Dronke, Women Writers of the Middle Ages, 39.

5. Marchand, "The Frankish Mother," 12.

6. Marcelle Thiébaux, The Writings of Medieval Women (New York: Garland Publishing Inc., 1987), 65-79, 68.

7. Peter Godman, Poetry of the Carolingian Renaissance (Norman: University of Oklahoma Press, 1985), 277.

8. "If we had not preserved the manuscripts of the Manual, we would be completely ignorant of Dhuoda. The Carolingian chroniclers often mention Bernard of Septimania but do not breathe a word about his wife." Pierre

Riché,'Introduction,'Dhouda, Liber Manualis, (Sources Chrétiennes, no. 225, Paris: Les Éditions Du Cerf, 1975), 16.

9. Riché, "Introduction," 21.

10. Arthur J. Zuckerman, A Jewish Princedom in Feudal France: $768-900$ (New York: Columbia University Press, 1972), 266-67.

11. Zuckerman, A Jewish Princedom, 268.

12. Paschasius Radbertus, Life of Wala, Charlemagne's Cousins: Contemporary Lives of Adalard and Wala, translated by Allen Cabaniss (New York: Syracuse University Press), 162.

13. Zuckerman, A Jewish Princedom, 273-85.

14. Dronke, Women Writers of the Middle Ages, 36; Riche, "Introduction," 18.

15. Zuckerman, A Jewish Princedom, 260; 264. Zuckerman asserts that Bernhard was "the Nasi [Prince of the Jews] scion of the Hebrew royal house of David"(264). him to raise him."

16. Riche, "Introduction," 20. "Bernhard wanted to have his second son close to

17. Dronke, Women Writers of the Middle Ages, 38.

18. Riche, "Introduction," 27. "We need not present Dhuoda simply as a loving and weak mother. This is a woman who devotes all her force and fortune ... to the service of the head of the family. 
19. Zuckerman, A Jewish Princedom, 122.

20. Pierre Riche, Daily Life in the World of Charlemagne, translated by Jo Ann McNamara (Liverpool: Liverpool University Press, 1978), 227. Cf. Pierre Riché, Education and Culture in the Barbarian West from the Sixth Through the Eighth Century, translated by John J. Contreni, (Columbia, S.C.: University of South Carolina Press, 1978). Riché speculates that the earlier "young Frankish women wished to imitate GalloRomans and become "as skillful with the pen as with weaving." Furthermore, he asserts, "Women played an important role in Merovingian life, and their culture was certainly less neglected than is usually thought" (221-22).

21. Riche, Daily Life in the World of Charlemagne, 225.

22. Riché, Daily Life in the World of Charlegmagne, 191.

23. Riché, Daily Life in the World of Charlemagne, 206.

24. Riché, Daily Life in the World of Charlemagne, 205.

25. Riche, Daily Life in the World of Charlemagne, 161.

26. Riche, Daily Life in the World of Charlemagne, 62-63.

27. J. M. Wallace-Hadrill, The Frankish Church (Oxford: Clarendon Press, 1983), 404. With Wallace-Hadrill's observation in mind, it is interesting to consider the scholarly debate regarding the possibility that Dhuoda is Charlemagne's daughter and Louis the Pious's sister (Zuckerman, A Jewish Princedom, 122-23 n 20). Furthermore, Zuckerman quotes L. Auzias's observation in L'Aquitaine, in which he identifies "Bernard as a powerful marquis" who for a brief period "had been the real King of France" (287).

28. Dronke, Women Writers of the Middle Ages, 36.

29. Dronke, Women Writers of the Middle Ages, 37.

30. Dronke, Women Writers of the Middle Ages, 43.

31. Marchand, "The Frankish Mother," 8.

32. Godman, Poetry of the Carolingian Renaissance, 52.

33. Thiébaux, The Writings of Medieval Women, 67.

34. Augustine of Hippo, Enchiridion, translated by Albert C. Outler (Philadelphia: Westminster Press, 1955), 337.

35. Augustine, Enchridion, 338.

36. Augustine, Enchridion, 339.

37. Thiébaux, The Writings of Medieval Women, 70. 
38. Thiébaux, The Writings of Medieval Women, 73.

39. Thiébaux, The Writings of Medieval Women, 74.

40. Thiébaux, The Writings of Medieval Women, 76.

41. Thiébaux, The Writings of Medieval Women, 73.

42. Riche, Daily Life in the World of Charlemagne, 81.

43. Riché, Daily Life in the World of Charlemagne, 81.

44. Riché, Daily Life in the World of Charlemagne, 82.

45. Riche, "Introduction," 14. "This quick historical review allows us to see the originality of Dhuoda's Manual. To begin with, it is not written by a cleric, but by a laywoman, and that gives it a unique place in the Latin literature of the high Middle Ages. In addition, it is a mother who addresses a book of education to her son, and it is likewise the only literary work of this kind."

46. Marchand, "The Frankish Mother," 25.

47. Marchand, "The Frankish Mother," 14.

48. Marchand, "The Frankish Mother," 14.

49. Riche, "Introduction," 19. See, Dhouda Liber Manualis, translated into French by Pierre Riché (Paris: Les Éditions Du Cerf, 1975), 86. Dhouda writes: “Audiui enim quod genitor tuus Bernardus in manus domni te commendauit Karoli regis; admoneo te ut huisus negotii dignitatem usque ad perfectum uoluntati operam des. Tamen, ... "

50. Marchand, "The Frankish Mother," 14.

51. Thiébaux, The Writings of Medieval Women, 70.

52. Thiébaux, The Writings of Medieval Women, 68-72.

53. Marchand, "The Frankish Mother," 21. To read it in the Latin, see Dhuoda, Liber Manualis, 202.

54. Et uelut columbae, lympham bibnentes limpidissimam, conspiciunt erodios atque rapaces accipitres, ne ab eis capiontur, euaduntque congratulantes et rransuolantes ubi eis ampla libuerit uoluptas: sic, to si dicta sanctorum ortodoxorum praecedentium patrum perqquieris legendo, seu et optimates ducum et consiliarios, ut tibi praedictum est, digne Deo et seniorum iussa dideli nisu complentes sonspexeris frequens, et eorum exempla inobliuiosus fueris adsecutus, non solum ab inuisibilibus insidiis malignorum spirituum. uerum busque dyndras poteris euadere, ... (Dhouda, Liber Manualis, 202.

55. Thiébaux, The Writings of Medieval Women, 68.

56. Thiébaux, The Writings of Medieval Women, 68. 
57. Marchand, "The Frankish Mother," 14.

58. Zuckerman, A Jewish Princedom, 286.

59. Riche, Daily Life in the World of Charlemagne, 220.

60. Marchand, "The Frankish Mother,"21.

61. Marchand, "The Frankish Mother," 18.

62. Riche, "Introduction," 29-30. In fact Dhuoda is very brief on that subject and says simply, "Confess in secret ... your sincere confessions, with sighs and tears." The confession to God, the direct dialogue with the Almighty, seems to Him, as effective as confession to a priest as a way to free oneself from sin ... . Dhuoda is also very discreet in that which concerns the sacrament of the Eucharist. Only with difficulty do we find a phrase about the sacrifice of the mass in the chapter about priests and a few lines about the offerings of masses for relief of the souls of dead.

63. Marchand, "The Frankish Mother," 18.

64. Marchand, "The Frankish Mother," 18.

65. Marchand, "The Frankish Mother," 18-19.

66. Marchand, "The Frankish Mother," 16-17.

67. Riche, Daily Life in the World of Charlemagne, 63.

68. Thiebaux, The Writings of Medieval Women, 75.

69. Dronke, Women Writers of the Middle Ages, 36. 


\section{CHAPTER IV}

\section{DIVINE DIALOGUES IN A DECADENT CENTURY HILDEGARD OF BINGEN: A FEMALE PROPHET FOR A "WOMANISH TIME"}

No doubt I differ from the mass of men on many points; for, to my mind, whoso hath skill to fence with words in an unjust cause, incurs the heaviest penalty; for such an one, confident that he can cast a decent veil of words o'er his injustice, dares to practise it. (Medea, 577-80)

Medea responds to Jason's argument: “Yea, men should have begotten children from some other source, no female race existing; thus would no evil ever have fallen on mankind" (573-75). In the last phrase of this statement, Jason expresses an opinion of women's contribution to human existence, not unlike the condemnations of Eve found in the writings of the early fathers of the Christian Church. In St. Justin the Martyr's "Dialogue with Trypho the Jew" (ca. A. D. 155), St. Justin accuses Eve of conceiving "the word of the serpent and [bearing] disobedience and death."1 St. Iranaeus in "Against Heresies" (A. D. 180/199), claims Eve "was made the cause of death for herself and the whole human race."2

In Euripides's play the Chorus participates briefly in the rhetorical exchange between Jason and Medea when it tells Jason bluntly "Thou hast sinned in casting over thy wife" and accuses him of using "specious art" (576). Medea's speech elaborates on the Chorus's term "specious art." Medea's point is that "skill to fence with words," the rhetoric Jason uses to argue with Medea and to justify his actions to others, not only "veils" injustice but also blurs the distinction between justice and injustice to the extent that an individual may mistake one for the other. According to Medea, this confusion "incurs the heaviest penalty" because it enables Jason to sin while deluding himself and others into thinking that his actions are those of a noble husband doing what is best for his wife and 
family. Medea's argument is based on the assumption that it is far worse to make sin look like justice than to answer injustice with sin.

In twelfth-century Europe, sixteen hundred years after Medea and the Chorus first accuse Jason of using "specious art," Hildegard of Bingen, a Benedictine abbess, uses Medea's argument to defend Eve against accusations, such as those cited above, and to chastise vigorously the religious and secular leaders who are her twelfth-century contemporaries.

In one of the last letters she wrote, Hildegard castigates the prelates of Mainz for placing her convent under interdict because she allowed an allegedly excommunicated nobleman to be buried in the convent cemetery. She ends the letter with the statement: "This is a 'womanish time,' for the justice of God dwindles away."3 Barbara Newman explains Hildegard's use of the phrase "womanish age" as an indictment of the misguided and deceitful leadership provided by men, which makes it necessary for a woman to assume responsibility: "She lived in a "womanish age" (muliebre tempus) in which men had become so lax, weak, and sensual--in a word, effeminate--that God had to confound them be making women virile."4

But Hildegard's visions and letters indicate that the concept of men as effeminate in terms of their moral fortitude is also closely tied to Adam's response to Eve when she gave him the apple from the Tree of the Knowledge of Good and Evil. As will be more fully explained later in this chapter, Adam, the first human to name things and therefore to use language, should have recognized that Eve had been deceived by the serpent. Hildegard's visions reveal that Adam is more culpable than Eve because he failed to use his superior reason and experience with words to avert the calamitous results of Eve's transgression. Like Adam, the religious and secular leaders who are on the receiving end of Hildegard's advice are accused of failing to recognize the Devil's deceitful rhetoric and of using specious rhetoric to justify their errors. Newman is correct in her interpretation of 
Hildegard's use of the phrase "womanish time" to refer to the fact that a woman must assume the moral high ground when men fail to do so. However, when the reader considers Hildegard's defense of Eve and explanation of Adam's culpability, the reader may also see that she is accusing men not so much of being gullible, weak, and effeminate like Eve but of failing to use their intuitive and scriptural understanding of God's will in favor of the fallible powers of human reason demonstrated by Eve. As a result, a woman must assume the responsibility Adam failed to assume when Eve offered him the apple in the Garden of Eden.

Essential to this idea is Hildegard's insistence that the words in her visionary books and most of her letters are not hers but God's. As Eve demonstrates in her conversation with the serpent and Medea explains to Jason, human words, rhetoric, can distort and hide the truth. The most deceitful sinful rhetoric is that which distorts and hides the truth of God's words. In the Garden of Eden, Satan distorts God's words and successfully tempts Eve. Weak, gullible Eve is deceived. But Adam who named things, and when he named Eve, did so in verse, accepts the apple without saying a word. In the letter to the prelates of Mainz from which the preceding quotation was taken, Hildegard quotes from a vision to explain why the interdict should be lifted from the convent so that she and her daughters can participate in the sacraments: "It is not good for you, because of the words of human beings, to forego the mysteries of my Word clothed in human nature and born as your salvation in the spotless womb of the Virgin Mary."5

For Hildegard, the most important of what she says in her visionary writing--and in most of her correspondence--is that she is not expressing her idea or opinion but that she is literally repeating the word of God. Therefore, her words are not vulnerable, as are the words that explain and describe human thought and experience, to interference from the Devil. A dominant theme in her visions and correspondence centers on the snake's rhetoric 
in the Garden of Eden and the ways in which Satan continues to insinuate himself into human rhetoric, misleading and corrupting even the most intelligent and honest people.

Essential to this agenda is the idea that Hildegard, "a poor weak woman" incapable of reasoning or analysis, could not possibly understand, think, and write what she does without divine assistance. For Hildegard. the humility topos is the foundation of her credibility as a New Testament prophet. On the other hand, this topos compounds the problem of considering her as the author of her text, especially for the reader trying to resist the tendency to dismiss her as either misinformed and deluded or as a mere amanuensis for a higher authority, human or divine. If the reader takes Hildegard literally, the latter conclusion, that which assumes divine authority, is the only option. Nevertheless, the voice in her writing is consistent and compelling. The imagery and style demonstrate a thorough understanding of human rhetoric and a creative talent, and the view presented of her historical context is valuable.

At age thirty-eight, a few years before Hildegard received God's command to communicate her visions in writing, she quite literally "comes forth from the house." She experienced her first vision at age three. ${ }^{6}$ Five years later she was enclosed with Jutta, an anchoress attached to the Benedictine monastery at Disibodenberg in the Rhineland. Although she was unable to articulate her early visions, her parents apparently recognized the religious intensity of their daughter's experiences and enclosed her instead of following the more common practice of entering a child in a convent as an oblate. Although both Hildegard and the few around her who knew about her visions did not fully understand them, Jutta, who was also responsible for Hildegard's education, discussed them with a monk, probably Volmar, who eventually became Hildegard's assistant. Even though Jutta and Volmar agreed that the visions were authentic, Hildegard did not make her experience public until three years after Jutta's death. 
Jutta died in 1136. At that time, Hildegard was elected to head what had become a small convent attached to the Benedictine monastery at Disibodenberg. Hildegard was probably the logical choice to replace Jutta as leader of this community that had developed, in part, as a response to their piety and enclosure. By 1141 Hildegard had begun writing her first book, the Scivias, and stepped forth from her sequestered life in the convent to become one of the most public women in twelfth-century Europe. At the age of forty-two, with the help of Volmar, Hildegard began to record the imagery and voices of her visions and the interpretations revealed with them. With her call from God to make her visions public and her election as abbess of the Disibodenberg convent, Hildegard began her career as God's prophet.

Godfrey, a monk from the Disibodenberg monastery, who, after Volmar's death, became Hildegard's secretary and the provost to the nuns at Rupertsberg, began writing Hildegard's biography in 1173, six years before she died. In it he quotes Hildegard's own explanation for her appearance at this time in history:

In the eleven hundredth year after Christ's incarnation, the teaching of the apostles and the burning justice which he had set in Christians and spiritual people began to grow sluggish and irresolute. In that period I was born, and my parents, amid sighs, vowed me to God. ${ }^{7}$

Like the Old Testament prophets, Hildegard came into the world to bring a message from God to a wayward Christian community. The eleventh-century conflicts between religious and secular power created schisms within the Church stemming from loyalty issues that were complicated by shifting the loci of political power.

The monastic reform movement that began at the Benedictine abbey of Cluny in Burgundy led to the founding of religious communities similar to the one at Disibodenberg (founded in 1105) throughout Europe and had a profound effect on the Church. The reformers deemed as unacceptable the system in which the pope anointed the German kings as Holy Roman Emperors and in which the kings had a role in the election of bishops and 
popes, because this system put the Church in a dependent position in relationship to secular power. Both kings and popes fought for the right to invest bishops. The eleventh-century reformist Pope Gregory VII (1073-85) claimed that all Christians, including the emperors, were subject to the pope as the successor of Peter and Christ's representative on earth. The Pope was, he claimed, the supreme judicial and spiritual earthly power. Pope Gregory attempted to end clerical marriage and simony, as had others before and after him. The royal control of bishops but the "investiture controversy" continued throughout Hildegard's lifetime, pitting popes and the clergy against kings and emperors in a battle over power. As a result, by the time Hildegard died in 1179 , she had served under twelve popes and had seen ten antipopes appointed to the See of St. Peter. ${ }^{8}$ Via sermons, personal interviews, and letters, she conversed with many of the powerful figures of her time, including popes, emperors, and kings. The extant documents of these conversations attest not only to her status as an important figure of her time but also to her own profound convictions about ethical secular as well as religious conduct.

In 1095, three years before Hildegard was born, Pope Urban II had exhorted Christians to recapture the Holy Sepulchre in Jerusalem. The response to this call led to the First Crusade. Although initially considered a positive manifestation of contemporary spiritual virility, the crusade degenerated, in many instances, into theft, brutality, forced baptism and murder, specifically directed at Jews. As the Crusaders made their way through Germany and other parts of Europe, Jews were massacred in a number of German cities. The chronicler of the Annals of Disibodenberg records with condemnation the massacres, ransacking, and looting that victimized Jews: "Some of them, although unwilling, took refuge in baptism lest they should lose both their lives and fortunes. However many were killed and their fortunes carried off by the Christians." 9

Thus Hildegard's assessment of her time in history as "steeped in wantonness"10 and as a time when "spiritual people began to grow sluggish and irresolute," seems an 
accurate description of a time marked by spiritual reform, on the one hand, and by murders in the name of God on the other, by religious enthusiasm and religious oppression, strife between local rulers and the German crown, and warfare between the crown and the papacy. The age when seen in this light would indeed require correction from the presence of an Old Testament prophet. Given Hildegard's view of the world into which she was born and its need for correctives as opposed to conversions, it is perhaps logical that her mission would be prophetic as opposed to apostolic. The fact that she was a woman was a critical factor in her role as a prophet as it is explained in her writing, but it did not preclude her usurping prerogatives usually reserved for men such as preaching to the laity and correcting the errors of secular as well as religious leaders.

But to what extent Hildegard as a girl questioned the authenticity of her visions must remain conjecture. She describes her feelings about her early visions thirty years later when she is seeking authorization from male religious authorities. Under these circumstances, it would be politically foolish to fail to admit that only a male cleric with considerable spiritual insight could firmly corroborate the authenticity of her visions and, thereby, also authorize her to continue to write them down and, more importantly, to make them public. Hildegard, however, has enough confidence in the authenticity of her experience to seek authorization from the most eminent sources. Bernard of Clairvaux, the first person to whom she writes to request authorization, had demonstrated some discretion in granting his approval of writing that might be somewhat unorthodox by asserting his skepticism regarding the work of Abelard, William of Conches, and Gilbert of Poitiers. ${ }^{11}$ However, in a letter Dronke describes as "perfunctory,"12 he gives Hildegard his blessing. Hildegard was an original and was apparently not deterred by Bernard's tepid response to her account of her visions. Later in the same year that she wrote to Bernard (1147), Hildegard also secured a more enthusiastic and public response to her visionary experience from Pope Eugene at the synod of Trier. ${ }^{13}$ Nor could they have known that, as her 
confidence grew with experience, although she initially gained her authorization from men, Hildegard would, from that point on, take her direction and authority not from men, but from God, with all the intensity and energy of a sanctified and authorized Medea.

The importance of authenticated visions to the process of establishing Hildegard's power must not, however, be underestimated. Elizabeth Petroff explains how visions enhanced the agenda of the female prophet and mystic:

Visions led women to the acquisition of power in the world while affirming their knowledge of themselves as women. Visions were a socially sanctioned activity that freed a woman from conventional female roles by identifying her as a genuine religious figure. They brought her to the attention of others, giving her a public language she could use to teach and learn... Visions allowed the medieval woman to be an artist, composing and refining her most profound experiences into a form that she could create and recreate for herself her entire life. ${ }^{14}$

Thus, the authorization of her visions not only empowers her but allows her to justify devoting the time and energy necessary to recording the visions and their interpretation and to demand the spaces and resources to do so. Lerner points out how the conventions of the female saint and mystic as outlined by Heffernan (that is, the importance of prophetic visions and freedom from the Pauline notions of sexual indebtedness) enhance Hildegard's opportunity to write: "Hildegard was privileged in her ability to free herself from traditional gender roles by living as part of a female community, enjoying what Sara Evans has listed as a precondition for feminist consciousness, 'free space."'15 While Lerner adds that this space is available to Hildegard as a marginalized member of a patriarchal society, the fact remains that this luxury, her training under Jutta, and years of continual exposure to the Catholic liturgy and ritual contribute substantially to her visionary experiences. Hildegard's visionary writings follow the pattern of scriptural description and exegesis. She describes each vision in detail followed by a quotation of the words she heard during the vision. The remaining text accompanying each vision explicates the imagery and words. The voice used in the explications shifts from Hildegard's to the voice of the vision 
and often it is not clear which of the two is speaking. After describing what she sees in the first vision of the Scivias, Hildegard repeats what she heard:

And behold, He Who was enthroned upon that mountain cried out in a strong, loud voice saying, "O human, who are fragile dust of the earth and ashes of ashes! Cry out and speak of the origin of pure salvation until those people are instructed, who, though they see the inmost contents of the Scriptures, do not wish to tell them or preach them, because they are lukewarm and sluggish in serving God's justice. . . Burst forth into a fountain of abundance and overflow with mystical knowledge, until they who now think you contemptible because of Eve's transgression are stirred up by the flood of your irrigation. ${ }^{16}$

Present in this introduction to the first of Hildegard's three visionary books are the two themes that run through Hildegard's work. One is the definition of her role as a visionary, as a prophet through whom God works as He worked through the Old Testament prophets. This definition includes the prophet's role as a scriptural exegesist and a license to scold anyone deserving it including popes and kings. The second theme is her use of the humility topos that includes not only the conventional authorization of a member of a marginalized segment of society as God's messenger but also a reworking of the biblically based argument that marginalizes all women through Eve. Not surprisingly, this process includes a rich dialogue with Scripture, patriarchs, and Church Fathers, especially St. Paul and Augustine. Hildegard's texts are the pastiche of scriptural and theological passages described by Bakhtin in Chapter I.

Included in the marching orders that she receives in the above quotation are echoes of Genesis, Job, Jeremiah, and St. Paul. The first humility topos, “Oh human, who are fragile dust of the earth and ashes!" echoes Job's repentance and admission of worthlessness. ${ }^{17}$ The order to "Cry out and speak" is similar to God's words to St. Paul, "Speak, and do not be silent." And, as Paul is told, "For I am with you,"18 God likewise reassures Hildegard that she is "receiving her insights" from "the lofty and tremendous Judge on high."19 
But, as happens frequently in Hildegard's visions, these references are recombined in ways that juxtapose ideas and provide the potential for interpretations unique to the version of scripture that Hildegard receives in her visions. The reference to Eve includes the image of Hildegard enlightening her fellow Christians "by the flood of [her] irrigation." In a subsequent paragraph, the text includes a reference to God as He who "in might and Kindness floods those who fear Him and serve Him in sweet love and humility, with the glory of heavenly enlightenments." While Hildegard is admittedly in a marginalized position because of her sex and her humanity, that position is elevated to one of like God, being able to "stir up," "flood," "irrigate," and "enlighten" humanity.

Hildegard is careful, when describing or talking about her visions, to highlight those elements that make it clear that her visions are those of the prophet not the mystic. In a letter to Guibert of Gembloux, a monk who inquired about the nature of her visions, she explains that she is fully conscious and does not experience the altered consciousness typical of the mystical experience.

But I do not see these things with my external eyes nor do I hear them with my external ears. I do not perceive them through the thoughts of my heart or through the mediation of my five senses. I see them much more in my soul alone, with my physical eyes open, in such a way that I never experience the unconsciousness of ecstasy, but I see all of this awake, whether by day or night. ${ }^{20}$

In addition to removing any hints of ecstasy from her visionary experience, Hildegard's description contains elements of Augustine's description in the Confessions of how one knows God. Augustine says that even though God gave him "the power of perceiving things by [the] senses," he must, however, "reach [God] through [his] soul."21

Hildegard undertook to make her visions public by writing them herself in "plain Latin words as [she] hear[s] them'22 rather than dictating them to a reliable male intermediary, of which there could have been no shortage in the attached monastery. It is not clear in Hildegard's statement whether the aural aspects of her visions were in Latin and, therefore, if Latin was Hildegard's choice or the language of the visions themselves. 
The fact that they are written in Latin designates a reader who is among the secular and religious, educated elite, an element of the population that also included many of the most of the powerful people in eleventh-century Europe. Even though she insists that she is poorly educated, Hildegard's texts are in the tradition of the scholar both in terms of the content and the language in which they were written. Hildegard deflects possible objections to a woman writing on subjects usually dealt with only by men in the language of scripture and scholarship by asserting that she speaks and writes "not by the invention of [her] heart or that of any other person, but as by the secret mysteries of God [she] hear[s] receive[s] them in the heavenly places". ${ }^{23}$ Although she accepts no responsibility for writing in Latin on theological subjects, the fact that she does places her in the company of theologians such as Augustine, Jerome, Peter Abelard, and Bernard of Clairvaux. Reinforcing the prophetic nature of her visions is the fact that she not only has direct access to God but, according to the visions themselves, she was chosen by God as His messenger through whom he speaks. In an autobiographical vision included in the Vita, Hildegard sees that God chose her for this purpose before she was born. Referring to an early vision in which Wisdom speaks to her, she says, "In my first formation, when in my mother's womb God raised me up with the breath of life, he fixed this vision in my soul.'24 This description, like many other passages in her writing, mirrors the words of Old Testament prophets, in this instance the words Jeremiah hears that tell him of his calling: "Before I formed you in the womb / I knew you, / and before you were born / I consecrated you; / I appointed you a prophet to the nations." 25 And, as Newman observes, Hildegard, in much of her writing, "lapses easily from speaking about God in the third person, as preacher, to speaking for him in the first person, as prophet; she also claims direct verbal inspiration for her entire opus and threatens terrible divine vengeance on anyone who dares to add, delete or alter a word." 26 In one of her letters, Hildegard describes herself as "a poor woman who listens to the instruction of the masters. I barely 
know the letters of the alphabet and I'm very much afraid to say or to write to the masters, i.e. to men, those things I have seen in my soul and in a true light without any perceptions of my external senses." 27

In spite of her professed lack of learning, God also reveals to Hildegard in the form of instant insight the meaning of the Scriptures, via her visions, with instructions about how to present and interpret these revelations. She explains in the Declaration of the Scivias, "And immediately I knew the meaning of the exposition of the Scriptures, namely the Psalter, the Gospel and the other Catholic volumes of both the Old and the New Testaments." 28 Thus, through Hildegard, God corrects erroneous exegesis and reinforces correct readings in spite of the fact that His prophet claims to have only a rudimentary knowledge of Scripture. As Newman explains, however, Hildegard's learning probably exceeded her assessment of it, but the denial of learning served both as a part of the humility topos and as an oblique critique of scholarly clerics who, in Hildegard's opinion, were misleading their followers with sophistry in addition to violating their clerical vows of chastity and poverty:

She was already well-acquainted with the Church Fathers and standard biblical commentaries when she wrote the Scivias, and by the end of her life was a woman of remarkably wide culture. Her posture as a simple, unlearned person was not intended to deceive; aside from reinforcing her prophetic persona, it constitutes an implicit critique of the learned clerics whose negligence, she believed, had necessitated her mission. ${ }^{29}$

Clearly, the problem confronting the task of looking at Hildegard's writing is not recognizing the humility topos, but rather, finding where the boundaries between Hildegard's words and those she claims come from another source are blurred (for example, Wisdom or one of the other allegorical figures that appear in her visions, or God himself). Even in her correspondence, she characteristically refers to points she makes as having been shown to her in a vision. In the "Declaration" that precedes the actual visions described and interpreted in the Scivias, Hildegard explains that, while she is "gazing ... 
at a heavenly vision," she hears "a voice from Heaven, saying, .. . 'Say and write what you see and hear." The instructions continue:

But since you are timid in speaking, and simple in expounding, and untaught in writing, speak and write these things not by a human mouth, and not by the understanding of human invention, and not by the requirements of human composition, but as you see and hear them on high in the heavenly places in the wonders of God. Explain these things in such a way the the hearer, receiving the words of his instructor, may expound them in those words, according to that will, vision and instruction. Thus therefore, $O$ human, speak these things that you see and hear. And write them not by yourself or any other human being, but by the will of Him Who knows, sees and disposes all things in the secrets of His mysteries. ${ }^{30}$

This is the visionary experience that prompts Hildegard to write to Bernard of Clairvaux for his sanction. In the same experience the voice tells her two more times to "write." The voice also explains, "The person [Hildegard] whom I have chosen . . . I have placed among great wonders, beyond the measure of the ancient people who saw in Me many secrets." B1 Barbara Newman notes the numerous similarities between this passage and others in Hildegard and passages in the bcoks of the prophets Jeremiah (1:67), and Ezekiel. (1:1).32 Parallels may also be found in Moses and Isaiah. Moses, objecting to his assignment, says "O my Lord, I am not eloquent, neither heretofore, or since thou hast spoken unto thy servant:, but I am slow of speech, and of tongue,"33 and Isaiah who identifies himself as unworthy of either his assigned task or his vision cries "And I said: Woe is me! for I am lost, for I am a man of unclean lips, and I dwell in the midst of a people of unclean lips: for mine eyes have seen the King, the Lord of hosts!'34 The God "who ... made man's mouth" accompanied Moses and taught Aaron, Moses's brother, to help Moses in his mission. He sent a seraphim to Isaiah to heal his mouth. Like Moses and Isaiah, Jeremiah also resists the call on the basis of his inadequacy and, as He does for Moses and Isaiah, God reassures Jeremiah that He will help him: "Then I said, 'Ah, Lord God! Behold, I do not know how to speak, for I am only a youth.' But the Lord said to 
Me, 'Do not say, "I am only a youth"; for to all to whom I send you you shall go, and whatever I command you, you shall speak.' "35

An important parallel between Jeremiah, Isaiah, and Hildegard is that, according to their texts, God asked each of them to write. Isaiah is commanded by God in much the same way Hildegard is to "go, write it before them on a tablet, and inscribe it in a book, that it may be for the time to come as a witness for ever: For they are a rebellious people, lying sons, sons who will not hear the instruction of the LORD.'36 And God's reason for insisting on Isaiah's writing is similar to Hildegard's mission in an "womanish time." God also gave Jeremiah the command to "Take thee a scroll, and write on it all the words that I have spoken to you." 37 Hildegard, however, explains that she herself "refused to write for a long time through doubt and bad opinion and the diversity of human words."38 Her suspicion of "the diversity of human words" is forcefully addressed in a passage at the end of her second visionary book, the Liber vitae meritorum quoted by Dronke. She explains that, when she writes her visions, she is like a "lute" being played by a higher power. Hildegard explains that the words in her visionary writing are written when she "utters Gods miracles not of herself but being touched by them." Therefore these are divine, not human, words and no human being should presume to edit or change them:

Therefore, if anyone of his own accord perversely add anything to these writings that goes beyond their clear intent, he deserves to be exposed to the punishments here described; or if anyone perversely remove any passage from them, he deserves to be banned from the joys that are here shown." 39

Newman explains, "[S]he seems to have cherished [her 'unpolished' style] as a mark that her inspiration must be divine because she herself scarcely knew how to write."40

The "diversity of human words" that Hildegard, in the "Declaration" to the Scivias, cites as a reason for her wariness about writing her visions was an essential element in Hildegard's agenda. It is profoundly important to Hildegard that the words she writes be divinely inspired. Human language and rhetoric can be used by the Devil just as he used 
them with Eve in the Garden of Eden. In Vision Two of the Scivias, the voice speaking through Hildegard explains how the Devil used words to carry out the sinister plan that resulted in the fall:

For he would not have known that this tree was forbidden them unless he had proved it by guileful questioning and by their answers. . . By first misleading Eve, so that she might flatter and caress Adam and thus win his assent since she more than any other creature could lead Adam to disobedience, having been made from his rib. 41

Thus, it is through "guileful questioning" of Eve that the Devil learns of the forbidden fruit, and it is his deceifful rhetoric that entices Eve to "flatter and caress" Adam into eating the apple: "But the serpent said to the woman, Ye shall not die: For God knows that when you eat it, then your eyes will be opened, and you will be like God, knowing good and evil."42 But it is also Eve's vulnerability to rhetoric that, according to Hildegard's visions, redeems her and the generations of women who follow from the odious culpability of being the sole cause of man's downfall.

Adam and Eve's banishment from Paradise is a theme that appears frequently and prominently in the visions. As Newman explains, Hildegard was not unique in her fascination with man's post-lapsarian grief, but, as both Newman and Lerner illustrate, Hildegard's presentation of Eve and the implications of her role in the fall counteracts the severely misogynistic readings prevalent in the writing of many of the church fathers.

For Hildegard, as for medieval Christians generally, the story of Paradise lost recounted in Genesis served as the touchstone for all meditation on man and woman. It explained their origin, end, and present plight, as well as their relations with God, Satan, and one another. Although the seer nowhere offered a full-scale commentary on the Genesis story, she returned time and again to the figures of Adam and Eve. Their creation, marriage, and banishment appear in one of her earliest visions (Scivias I.2) and still occupied her on her deathbed. ${ }^{43}$

For medieval theologians following in the Pauline tradition, Genesis 3 is not simply about human nature. Rather, it is about a representative woman. Because of the important role she plays in the drama, Eve's sin--not humankind's sin--is highlighted. Adam, the first man, is the first to heap blame on Eve. When God calls to them in the Garden, because 
they know that they are naked, He realizes that they have eaten the forbidden fruit. He challenges them, and Adam points the finger of blame at Eve: "The woman whom thou gavest to be with me, she gave me fruit of the tree, and I ate." 44 Paul follows Adam's example. In his letter to Timothy, he clearly and authoritatively states to his Christian audience, "And Adam was not deceived, but the woman was deceived and became a transgressor." 45 Thus, according to Paul, Adam was not tricked because he was strong; Eve sinned because she was weak. The author of Genesis 3 never explains why the serpent chooses Eve to tempt, nor why it is she who first succumbs to temptation. St. Paul's exegesis of Genesis provides the scriptural explanation that Justin, Iranaeus, Jerome and many of prominent theologians who followed his lead reinforce. Tertullian demands of woman:

Do you not realize, Eve, that it is you? The curse God pronounced on your sex weighs still on the world. Guilty, you must bear its hardships. You are the devil's gateway, you desecrated the fatal tree, you first betrayed the law of God, you softened up with your cajoling words the man against whom the devil could rot prevail by force. The image of God, Adam, you broke him as if he were a plaything. You deserved death, and it was the son of God who had to die! 46

In spite of Hildegard's efforts to redeem her, the condemnation of Eve promoted by Paul and Tertullian prevailed. Two centuries after Hildegard died, Heinrich Kramer and Jakob Sprenger, Dominican inquisitors, wrote Malleus Maleficarum (c. 1486), a handbook on how to detect and eliminate witchcraft. The handbook was influential and widely read for centuries after it was written. In it, the authors express an assessment of Eve that echoes Tertullian's:

For though the devil tempted Eve to sin, yet Eve seduced Adam. And as the sin of Eve would not have brought death to our soul and body unless the sin had afterwards passed on to Adam, to which he was tempted by Eve, not by the devil, therefore she is more bitter than death. ${ }^{47}$

Augustine, in contrast to the other church fathers cited in this chapter, offers a different and not quite so Eve-condemning point of view of the events in the Garden of 
Eden.. In the City of God, written between 413-26, Augustine points to Adam's culpability.

We must believe that Adam transgressed the law of God, not because he was deceived into believing that the lie was true, but because in obedience to a social compulsion he yielded to Eve, as husband to wife, as the only man in the world to the only woman. It was not without reason that the Apostle wrote: "Adam was not deceived but the woman was deceived." He means, no doubt, that Eve accepted the serpent's word as true, whereas Adam refused to be separated from his partner even in a union of sin--not, of course, that he was, on that account, any less guilty, since he sinned knowingly and deliberately. . . To summarize briefly: though not equally deceived by believing the serpent, they equally sinned and were caught and ensnared by the Devil. 48

Like Augustine, Hildegard sees Adam as an accomplice, but, unlike Augustine, Hildegard claims that Adam committed an even greater sin than Eve because, in eating the apple, Adam sinned twice; he not only disobeyed God, he also failed to use his intelligence and authority to explain to Eve the serpent's intent and thereby prevent the sin. Hildegard suggests that readers who identify women as "contemptible because of Eve's transgression" are imitating Satan's sentiments. According to Hildegard, Satan hates Eve because her children are intended to replace his fallen angels in Heaven. Satan's jealousy of Eve is explained in Hildegard's commentary on the woman clothed with the sun whom she identifies as Eve.

When the old dragon saw that he had lost the place in which he wished to establish himself, he turned his wrath against the woman, for he recognized that as the childbearer she was the root of the whole human species. He conceived a mighty hatred against her and said to himself that he would never cease his persecution until he drowned her in the sea... With protection from heaven she opposed the Devil in every way. To her were given two bulwarks of bliss: the desire for heaven and the protection of souls. Through them she was to strive for the mysteries of her heart. There she was to grasp the nourishment of salvation. ${ }^{49}$

Hildegard, ignoring almost all of the Church Fathers and Scripture, quite literally sees things differently. While Hildegard acknowledges that Eve's weakness made her more vulnerable than Adam, Hildegard interprets this vulnerability as good rather than bad for mankind. Newman explains Hildegard's reasoning: 
The issue of guilt seemed almost irrelevant when Hildegard wrote that "If Adam had sinned before Eve, that transgression would have been so grave and incorrigible, and man would have fallen into such great, unredeemable stubbornness, that he neither would nor could be saved. Hence, because Eve transgressed first, the sin could more easily be undone, since she was weaker than the male." Here again, the ambiguous frailty of woman makes her more susceptible to both temptation and redemption, just as her "airiness" opens her to both the Holy Spirit and the demonic powers of the air. ${ }^{50}$

And, as Gerda Lerner explains, Hildegard was among the first of centuries of women who tried to rethink the story of the Fall because, as women, they recognized and wanted to redress the marginalizing effects of the patristic interpretation of Genesis 3: "Hildegard, in her retelling of the story of the Fall, removes the blame for the Fall from Eve and all women. Instead, the Fall becomes almost preordained by the bodily weakness built into Eve by the Creator. We will see this version of the Fall retold by many women in later centuries."51

Although Hildegard's visionary rewriting of Eve is intriguing, just as intriguing is the rhetorical fit between this interpretation of Eve's role in the fall and Hildegard's assessment of the twelfth century as an "womanish time." Eve was vulnerable to the Devil's rhetoric because she was more innocent and less experienced in the use of words. But Adam, the man who named things, should have recognized the deceit in the Devil's logic and, instead of capitulating to Eve, should have dissuaded her. Thus, when Hildegard reports on satanic forces shown her in visions (whether it is documented in her trilogy or in her correspondence) she often refers to the Devil's speech or repeats his dialogue. For example, in the third vision of the Scivias, the reader is warned against the Devil's enticing rhetoric on magic: "He speaks to them deceitfully and shows them one sort of creature in their scrutiny as if it were another. . but you forsake Me, the true God, and imitate him who is a liar." 52 In a brief letter to King Henry II of England, Hildegard repeats the deceifful words of "a bird black as pitch," a figure that frequently appears in her visions as an emissary of the Devil: "You have the possibility of doing whatever you want. 
So do this and that; open the door to such and such a matter. It doesn't do you any good to pay attention to justice. If you always keep your eye on justice, you will be a slave, not a master."53 The black bird's speech here is alarmingly close to the questions and suggestions used by the serpent to seduce Eve. But Henry, who has roused Hildegard's ire by supporting an antipope and taking the wrong side in the religious conflicts in England, is one of Adam's heirs, not one of Eve's female descendants. As the inheritor of the power to name, define, and use reason, Henry should have recognized, as Adam did not, the Devil's rhetoric. But according to Hildegard's vision, Henry, in succumbing to Satan's guile, demonstrates a vulnerability similar to Eve's. Like Adam, he is more culpable than Eve because, as part of the patriarchal system, he should naturally understands how language works better than Eve does. According to Hildegard's vision, however, Henry, like Adam, is failing to recognize the Devil's rhetoric. Ironically, it is, therefore, the responsibility of a woman, Hildegard as prophet, to do for Henry what Adam failed to do for Eve: to point out the chicanery in the Devil's logic and dissuade Henry from being misled by it. And Henry is just one of the many recipients of Hildegard's visionary invective against a "womanish time."

Hildegard's reputation as a source of doctrinal interpretation as it applied to contemporary problems is attested to by the numerous occasions on which male clergy turn to her for theological advice. On a trip through the Rhineland in 1160, Hildegard stopped in Cologne where she chided the clergy of the cathedral for their their lack of vigor in response to the Cathar heresy. They were apparently inspired enough to request more advice about how to correct their behavior. Hildegard, in her role as a prophet, levels a series of scathing epithets at those who were lax in their opposition to the Cathars:

The Divine Who was and Who is and Who is to come speaks to the shepherds of the Church: "Beloved sons, you pasture my flocks according to the explicit direction of God's words. Why are you not ashamed, then, when you see how all the other creatures on the face of the Earth don't neglect, but rather fulfill, the directions they have from their Master?. . But your tongues are dumb despite the 
loud-calling trumpet blasts of the voice of the Divine. You don't love the holy knowledge that, like the stars, has its own course. . . You are like a naked snake that creeps into its hole. It is in much the same way that you give yourselves over to the stench of the lowest beasts. . . Whatever your flesh desires, that's what you do... [S]oon you'll all be soldiers, then slaves, then buffoons. With your empty and silly behavior, you might well be good for nothing more than to scare away some flies in the summer!. . The Devil himself is able to look at you and say: "with you I can find everything I need: . . "54

Here, the recipients of the letter are themselves accused of deceiving themselves with rhetoric: "You don't allow the people to seek teaching from you, since you say: 'It's impossible for us to do everything." This is just one of numerous letters to clergy in which the God speaking through Hildegard is clearly the Old Testament angry and judgmental God. Newman describes Hildegard's perceived mission as an order from God to "with her prophetic charism ... do what professional clerics had failed to do with their priestly charism: teach, preach, interpret the Scriptures and proclaim the justice of God."55

But Hildegard, in her role as prophetic teacher, could also be the compassionate New Testament God. For example, a priest wrote to her to ask: "How should I respond to someone who wants to receive communion but suffers from frequent bouts of vomiting?" Hildegard answers in her own words with a dialectical alternative to the usual practice of communion. The vomiting person should not physically receive communion because "the Body of Christ" is contained in the bread. He can receive it spiritually. The priest should "hold the Body of Christ over the head of such a person and beseech God, who has sent the soul into the body of this person, to heal the soul of this person through the divine Body and Blood."36 Clearly, although she claims divine revelation for much of what she says, she demonstrates here her ability to analyze a situation rationally and to solve a problem. Hildegard demonstrates her strong conviction against extremes in any matter but especially in the matter of penance. In a letter of reply to an abbot who consults her regarding a monk who has strayed and wants to return to the fold, the question is the 
degree of penance that should be required of the monk in order for him to rejoin his brothers.

Give him counsel so that he doesn't destroy his body through unreasonable abstinence and end up fading away with weakness. Give him a moderate penance through which he can overcome the Devil who is seeking to outwit him. ... For the old serpent hides itself in immoderate mortifications so that it can outwit and catch all those who strive after virtue without wise discernment. ${ }^{57}$

Likewise, in her visionary advice to her younger contemporary, the mystic Elizabeth of Schönau, in the voice of the "clear light" she warns that extremes are "devilish stratagem" and the result of pride not manifestations of piety: "Such a person lives then without hope and without joy. It's not unusual for her zest for life to disappear and she will be seized by a heavy illness. Through this devilish stratagem the person is robbed of the merits of holiness." 58 And, at times, Hildegard provides counselling to the clergy. For example, she writes to a priest with sleeping problems, characteristically explaining that his insomnia and nightmares, like other evils, are the work of the devil. She offers the following prescription: "Read every night in a prayerful state of soul, with your hand laid on your heart, the opening words of John's Gospel: "In the beginning was the Word"... May the Holy Spirit make you a tent of holiness, so that you may always live with God in the joys of the highest blessedness." 59

Whether in her own words or as a prophet, Hildegard did not restrict her advice to her colleagues in religious orders or to those who requested it. Like Samuel, she found it necessary at times to take kings to task. Certainly the boldest of these critiques is the tongue-lashing she gives Emperor Frederick Barbarossa. Although they had been on friendly terms and she could be said to owe him a debt of gratitude for granting an imperial charter of protection to the convent at Rupertsberg, Frederick had twice supported an antipope, Victor IV in 1159 and a second in 1164 after Victor died. Thus, ecclesiastically Frederick was a schismatic. In her letter, she accuses him of behaving like a madman and warns him that the grace of God within him is in danger of being extinguished. 60 In her 
second letter to Frederick, Hildegard opens with a reminder of Satan's role in the Garden of Eden and Adam's folly in not recognizing the Devil's guile: "Because Adam violated [the] law through disobedience -- not keeping in mind that he agreed to obey the law, . . the death penalty fell on him... The evil spirits immediately began to lay snares for him ... to set traps of betrayal on every one of his paths." 61

Rhetorically, the most interesting of her confrontations with authority occurred in 1178 when Hildegard and her community were placed under an interdict by the prelates of Mainz for allowing an excommunicated nobleman to be buried in the consecrated churchyard at Rupertsberg. The Church officials wanted the body removed from the Rupertsberg cemetery. Hildegard refused on the grounds that the man in question had been reconciled with the church and received the sacraments before he died. The interdict meant that the community could neither partake of the Eucharist nor sing the divine office. Hildegard wrote to the prelates of Mainz and firmly explained her reasons for her refusal to follow their orders:

... I looked to the true light and with open eyes I saw the following words in my soul: If we were to follow your instruction and dig up the body of this dead man, then through that removal a great danger would threaten our locale and would beset us like the black cloud which serves to point out coming storms and bad weather. Therefore, we do not presume to dig up the body of the deceased, since he went to confession, received anointing and communion, and was buried without opposition. Also, we agree neither with the counsel nor the instruction of those who told and ordered us to do this. ${ }^{62}$

Although convinced that her decision is based on a moral imperative, she obeys the terms of the interdict, and, therefore, avoids a direct confrontation with her superiors "lest we appear to be disobedient." Rather than complying with their orders, she conceals the nobleman's grave. In "The Rule of Saint Benedict," one of the items reads that monks were obligated "to obey in all things the commands of the abbot, even though he himself (which God forbid) should act otherwise: remembering the Lord's precept: What they say, do you; but what they do, do ye not."63 This splitting of hairs between obeying God 
in terms of refusing to exhume the nobleman and obeying the prelate in terms of the interdict is not a formula one would expect to be revealed in a prophetic vision.

The consequences of Hildegard's course of action should not be underestimated. Indeed, not only was the monastic community publicly humiliated by the interdict, but, for six months the convent was deprived of mass, sacraments, and the right to sing their unique liturgical chant. As a result, Hildegard and her "sisters" were soon overcome with "great sorrow" and almost "overwhelmed" with "a heavy burden" and feelings of "enormous sorrow" and "great bitterness." Coincident with these feelings, Hildegard has another vision that she also included in her letter to the prelates of Mainz. This vision is an apology, by way of explanation, for music and its role in the spiritual life. The first part of the vision addresses the nature and purpose of the mass. In it Hildegard hears the voice of God commanding her not to neglect the sacraments. But rather than advising her to defy the prelates, the voice exhorts her to seek to have the ban lifted. In addition, it is explains to Hildegard that music is man's God-given method of coming to a fuller understanding of pre-lapsarian innocence. When Adam fell, he also lost the ability to harmonize with the angels in praise of God. Therefore, so that God would not be completely deprived of the praise that was due Him, he inspired prophets (including Hildegard) and others to compose psalms and hymns and to invent instruments so that they could praise God in a manner approaching that of the angels. Once it is revealed that music is divinely ordained, anything or anyone that prevents it is an agent of the Devil.

But when Adam's traitor, the Devil, heard that humans through God's inspiration had begun to sing and saw themselves thereby invited to think about the lovely songs of their heavenly homeland, then that same evil spirit suspected that his scheming machinations might be thwarted.... [Therefore] he thinks and seeks unceasingly to bring to disharmony, and even to ban, God's praise and the beauty of spiritual songs. ${ }^{64}$

Since Hildegard herself was a composer and musician well-known beyond her community in Rupertsberg, it is not surprising that she should have had strong feelings about the 
importance of music. Clearly, her vision demonstrates that her feelings are justified. The ban was lifted in March 1179, only a few months before Hildegard's death. That neither her nuns nor the Belgian monk, Guibert of Gembloux, who was acting as her secretary, deserted her during this ordeal is a testament to the loyalty she was accorded by many who were close to her. 65

Like Perpetua and Dhuoda, Hildegard was not a "poor weak woman who sits with folded hands," but rather, like Dhuoda, "of another mould, dangerous to foes and welldisposed [and loyal] to friends." Unlike Perpetua and Dhuoda, Hildegard was a twelfthcentury Benedictine nun. Like Dhuoda, Hildegard lived in a German-speaking country where the status of women was less burdened by patriarchal misogyny than it was in Anglo-Norman society. On the continent, conditions varied regarding what various cultures deemed the appropriate role for women in Church. Thus, in the German-speaking areas, Benedictine women like Hildegard of Bingen and Gertrude the Great (thirteenthcentury) were able to serve as influential spiritual writers and counsellors. ${ }^{66}$

"Hildegard of Bingen," Peter Dronke aptly asserts in his essay on her work, "still confronts us, after eight centuries, as an overpowering, electrifying presence--and in many ways an enigmatic one." Dronke explains:

Compared with what earlier and later women writers have left us, the volume of her work is vast. In its range that work is unique. In the Middle Ages only Avicenna is in some ways comparable: cosmology, ethics, medicine and mystical poetry were among the fields conquered by both the eleventh-century Persian master and the twelfth-century Rhenish sibyl. In more recent centuries, Goethe--who saw and was astonished by the illuminated Scivias manuscript in Wiesbaden--shows perhaps most affinity to that combination of poetic, scientific and mystic impulses, that freedom with images and ideas, which characterized Hildegard. ${ }^{67}$

Dronke's comparison of Hildegard and Goethe is high praise, especially given the fact that he acknowledges her "poetic" as well as scientific and "mystic impulses." However, his use of the word "impulses" suggest that he prefers to avoid actually calling her a poet. Few of the scholars who have studied Hildegard extensively comment at any length on her 
contribution to history or her writing as art, and her illuminations are usually treated as elaborate glosses on the text. Nevertheless either in spite of or because of her divine sources, Hildegard's writing is a potent, rich, labyrinth of images and symbols much like a verbal forerunner of the elaborate tapestries created by European weavers in the fourteenth and fifteenth centuries. 


\section{ENDNOTES}

1. Justin the Martyr, "Dialogue with Trypho the Jew," Faith of the Early Fathers: A Source-Book of Theological and Historical Passages from the Christian Writings of the Pre-Nicene and Nicene Eras, translated by W. A. Jurgens, 58-63 (Collegeville: The Liturgical Press, 1970), 62.

2. Irenaeus, "Against Heresies," Eaith of the Early Fathers: A Source-Book of Theological and Historical Passages from the Christian Writings of the Pre-Nicene and Nicene Eras, translated by W. A. Jurgens, 84-104 (Collegeville: The Liturgical Press, 1970), 93.

3. Fox, "Letter Forty-One," 359.

4. Newman, Sister of Wisdom, 3.

5. Fox, "Letter Forty-One," 335.

6. For this information and all the background information on Hildegard and her historical context follows, I am indebted to Emilie Zum Brunn and Georgette EpineyBurgard, "Hildegard of Bingen," Women Mystics in Medieval Europe, translated by Sheila Hughes (New York: Paragon House, 1989), 3-36; Sabina Flanagan, Hildegard of Bingen: A Visionary Life (London: Routledge, 1989); Barbara Newman, "Introduction," in Hildegard of Bingen, Scivias.

7. Fiona Bowie and Oliver Davies, Hildegard of Bingen: Mystical Writings, translated by Robert Carver (New York: Crossroad Publishing Co., 1990), 63

8. Sabina Flanagan, A Visionary Life (New York: Routledge, 1990), 16-20.

9. Flanagan, A Visionary Life, 21.

10 Bowie and Davies, "Letter Six," 134. According to the foreword to the letter, Anastasius IV was Pope between July 12,1153, and December 3,1154. Although he reputedly had a good reputation, he apparently tolerated less upright men in positions of influence. Hildegard took him to task writing,"So it is, $\mathrm{O}$ man, that you who sit in the chief seat of the Lord, hold him in contempt when you embrace evil, since you do not reject it but kiss it, by silently tolerating it in depraved men."

11. Dronke, Women Writers, 149.

12. Dronke, Women Writers, 149.

13. Dronke, Women Writers, 148.

14. Petroff, Medieval Women's Visionary Literature, 6.

15. Lerner, The Creation of Feminist consciousness, .58.

16. Hildegard of Bingen, "Vision One," Scivias, translated by Mother Columba Hart and Jane Bishop (New York: Paulist Press, 1990), 67. 
17. Job 42: 6; Job 30:19.

18. Acts 18:9-10.

19. Acts $18: 9$; Acts $18: 9-10$

20. Fox, "Letter thirty-Nine," 349.

21. Augustine, Confessions, translated by Edward Bouverie Pusey (Chicago: William Benton Publisher, 1952), 33.

22. Fox, "Letter forty," 350.

23. Hildegard of Bingen, Scivias, 61.

24. Bowie and Davies, Hildegard of Bingen: Mystical Writings, 63.

25. Jeremiah 1:5.

26. Newman, "Introduction," 18.

27. Hildegard of Bingen, Scivias, 59.

28. Hildegard of Bingen, Scivias, 59.

29. Newman, Sister of Wisdom, 17-18.

31. Hildegard of Bingen, Scivias, 59.

32. Hildegard of Bingen, Scivias, 60 .

33. Newman, "Introduction," 26.

34. Exodus 4:11.

35. Isaiah 6:5.

36. Jeremiah 1:6-7

37. Isaiah 30:8.

38. Jeremiah 36:2.

39. Hildegard of Bingen, Scivias, 60.

40. Dronke, Women Writers,. 160.

41. Newman, "Introduction," 23.

42. Hildegard of Bingen, Scivias, 77. 
43. Genesis 3:4-5.

44. Newman, Sister of Wisdom, 89.

45. Genesis 4:12

46. I Timothy 2:14.

47. Marina Warner, Alone of All Her Sex: The Myth and the Cult of the Virgin Mary (New York: Random House Inc., 1976), 58.

48. Heinrich Kramer and Jakob Sprenger, Malleus Maleficarum, 1486? translated by Montague Summers (London: Pushkin Press, 1951), 47.

49. Augustine, City of God, translated by Gerald G. Walsh, et al., (New York: Doubleday, 1958), 306-07.

50. Hildegard of Bingen, Book of Divine Works, 172-73.

51. Newman, Sister of Wisdom, 115.

52. Lerner, The Creation of Feminist Consciousness, 61.

53. Hildegard of Bingen, Scivias, 101.

54. Fox, "Letter Ten,"292-93.

55. Hildegard of Bingen, "Letter Twenty-four," 322-28, 322-23.

56. Newman, "Introduction," 12.

57. Fox, "Letter Thirty," 335.

58. Fox, "Letter Twenty-Nine," 334-35.

59. Fox, "Letter Thirty-five," 340-42, 341.

60. Fox, "Letter Twenty-Eight," 333-34.

61. Bowie and Davies, Hildegard of Bingen: Mystical Writings, 38-40.

62. Fox, "Letter Eight," 290-92, 290.

63. Fox, "Letter Forty-One," 354-59. For all the information which follows on the interdict, I am indebted to Flanagan, A Visionary Life, 184-190; Newman, "Introduction," 15-16; Newman, Sister of Wisdom, 14.

64. Benedict of Nursia, The Rule of Saint Benedict, 210.

65. Fox, "Letter Forty-One," 358. 
66. This is the same monk who was fascinated by her visions and with whom she corresponded regarding her inner visionary experience. Newman, "Introduction," 16.

67. Terrence Kardong, OSB, The Benedictines (Delaware: Michael Glazier, Inc., 1988), 160.

68. Dronke, Women Writers, 144. 


\section{CHAPTER V}

\section{CONCLUSION}

Who peyntede the leon, tel me who?

By God, if wommen hadde writen stories, As clerkes han withinne hire oratories, They wolde han writen of men moore wikkednesse

Than al the mark of Adam may redresse.

Chaucer, Canterbury Tales, "Wife of Bath's Prologue" ( 692-696)

In her prologue, Chaucer's Wife of Bath, Alison, precedes this speech with a report concerning a disagreement she had with her former husband, a clerk named Jankyn. He read constantly from a book containing numerous stories about women. Although Medea is not mentioned in the list of women the Wife of Bath provides following this quotation, Alisoun's description of the women catalogued in her husband's book indicates that Medea may have been included, but Alison does not mention her. The disagreement between Alison and Jankyn arose over the fact that Alison found Jankyn's choice of reading material offensive. The question she poses, "Who peyntede the leon, tel me who?" raises the issue faced by every woman who, like Alison, tries to make meaning out of her experience and express her thoughts; the dynamic patterns and available metaphors have been painted by men. Although not all of them are hideous Medeas, all are endowed, in some way, with marginalizing tropes.

Nevertheless, male thinkers and writers have provided their female contemporaries with some useful material, not the least of which is Alison of Bath who, to be fair, comes off no worse, and somewhat better than many of the men portrayed in the Canterbury Tales. She is not a vicious Medea or a simple-minded, gullible Eve. Nor is she a saintly Virgin Mary, muted and obedient, and yet the most public female figure in the Judeo- 
Christian tradition. The Wife of Bath is a business-woman, and she has outlived five husbands. She is Medea in her outspoken criticism of men's negative views of women and her brazen disregard for the boundaries between the domestic and the public arenas. She is Eve in her earthy vulnerability to logic that lacks the linear clarity men claim sets their reasoning apart from women's.

In the above speech, the Wife of Bath also brings up the issue addressed by the Corinthian ladies, in the lines quoted at the beginning of Chapter II,

Honour's dawn is breaking for woman's sex; no more shall the foul tongue of slander fix upon us. The songs of the poets of old shall cease to make our faithlessness their theme. Pheobus, lord of minstrelsy, hath not implanted in our mind the gift of heavenly song, else had I sung an answering strain to the race of males, for time's long chapter affords many a theme on their sex as well as ours. (Medea, 435-45)

Like the Wife of Bath, the Chorus of Corinthian ladies suggests that the metaphors might be different had women been allowed to sing "an answering strain to the race of males"; perhaps more female heroes would be recorded in the pages of history, and in legend and literature men and women would be held equally culpable for the evil in the world. As the lion demonstrates in the fable, the picture is different when he paints it. Likewise, the Wife of Bath and the Corinthian ladies point to the possibility that if women helped create the patterns and metaphors of public discourse in the same way that men do, men might see a very different picture of themselves as well as of women.

A question Alison and the Corinthian ladies do not ask is this: What kind of pictures do women paint even though the available words and imagery embedded in the mnemonic meaning-making systems are dominated by a male perspective? This question shifts the focus from the distortions of male images of women to what women do with the "language world" available to them: How do they modify the metaphors to express a woman's agenda? What new patterns and metaphors do they create? To what extent are these metaphors available to other women to use as rhetorical raw material in the creation of 
other new metaphors? To look at women's writing, this way it is helpful to put aside the assumption that women who accept their marginalization are, by definition, willing victims who participate in.the system that oppresses them by not openly defying it. This assumption leads to a second assumption that can adversely effect the reading of women writers; women who accept their marginalization also accept as fact the implication that they are inferior to men and, therefore, inferior writers. Once these assumptions are put aside, the reader may look for women who, while they accept women's subordinate position in relation to men, do not accept the implication that they are by definition inferior to men. Regarding the works of Perpetua, Dhuoda, and Hildegard, a reading based on this assumption reveals women who present themselves in their texts as capable and talented thinkers and writers who consider their agendas as at least as important as those of their male contemporaries.

Perpetua chose to be a Christian and chose not to renounce her faith in order to save her life. She also chose to record her experience in writing. These choices place Perpetua in the public discourse arena. Unlike Blandina, Perpetua uses this opportunity to create a document that tells her story the way she defined and interpreted it. Evidence suggests that she uses metaphors provided by the classical Greek male playwright Euripides in his Iphigeneia at Aulis. Perpetua's reworking of Euripides's metaphor contains elements not included in his icon of a female hero. Perpetua tells her reader about an event that is considered documented historical fact. She also illustrates the problem faced by converts, male and female, of separating from pagan relatives and friends. But it is the elements of her narrative that parallel Euripides's portrayal of Iphigeneia that provide what Heffernan identifies as the conventions for women writers in the Christian tradition for over a thousand years after Perpetua died in the arena. Perpetua turns away from her biological family toward a spiritual family in much the same way that Iphigeneia turns away from her parents to become a heroic daughter of Greece. For both women this turning away 
involves the metaphor of death as a marriage to spiritual spouses. Essential to their roles as brides they must be young virgins. Perpetua's use of visions in her narrative may have been inspired by Greco-Roman seers and oracles, by what she had learned about Old Testament prophets, or by a merging of the two in her metaphoric field. To this list might also be added the authorization to write about her experience. Although Perpetua's text was muted in the centuries following her martyrdom, the conventions it later helped to establish provided opportunities that might not otherwise have been available to the women who followed her. The emphasis on virginity and redefinition of family provided religious women with roles other than the traditional secular responsibilities of wife and mother. This new choice gave them the opportunity to have an intellectual life and legitimated their desire to study and write. Authorized visions gave religious women writers a vehicle for theological insights and power in the public discourse arena and enabled them to have and intellectual life and to write about it without appearing to threaten the openly cerebral efforts of their male colleagues. Even though visions may have prevented these females from assuming ownership of what they wrote, they were, in fact, permitted to own the experience by putting their names on the document. While some might wish that Perpetua had provided more positive metaphors for the martyrs, holy women, and visionaries who followed her, surely the metaphors she gave women are better than alternatives such as the tropes provided by the male author of Blandina's martyrdom. Had Blandina's narrative prevailed as firmly as Perpetua's, it is conceivable that it may never have occurred to Dhuoda and Hildegard to be active participants in the public discourse arena. Or if it did, them may have had to leave it to men to write their stories for them, as some scholars suggest they did.

Dronke suggests that Dhuoda's unorthodox, "subversive" ideas regarding religious devotion "may well be why her work did not become widely adopted and diffused in learned circles."' It must also be remembered that it is the Griselda metaphor infused into 
literature through male authors, such as Chaucer, that may have prevented Dronke from fully realizing just how subversive Dhuoda's text is. If Dhuoda were a pathetic Griselda, is doubtful that it would have occurred to her to write. While Dhuoda is justifiably saddened by her circumstances, the text of Dhuoda's Manual indicates that she writes because she is an active participant in the family's campaign to maintain its power, prestige and property. As a well-educated and well-read noblewoman, the models and metaphors available to Dhuoda included both Augustine's Enchiridion, and the mirror-manuals written by eighth and ninth-century clerics to guide secular noblemen in their spiritual conduct. Dhuoda adopts this format--the pastiche of scriptural citations and other rhetorical elements popular among Carolingian writers--and skillfully blends them to serve her unique agenda. Through the Manual, she uses her role as William's mother to contribute to the family's agenda in a way that Bernard cannot. Dhuoda's purpose in writing is to infiltrate the court of Charles the Bald with her Manual and provide guidance for her son as he negotiates his way through a treacherous political situation. At the same time, she impresses upon him the importance of not being coerced into aligning himself with parties hostile to the family's interests. The humility topos that Dhuoda uses in virtually every reference to herself becomes part of her art and an essential ingredient in her purpose for writing. Dhuoda deftly varies the imagery and tropes with which she describes her deficiencies as a thinker and writer while reminding potentially hostile that she is only a loving mother and a weak woman with a feeble intellect. The reader who accepts these statements at face value would hardly expect such an author to write a seriously subversive document. Dronke is undoubtedly correct when he speculates that the Manual's unorthodox religious advice may have contributed to the fact that it was not more widely read. A related factor in the in the manual's narrow readership may be Dhuoda's emphasis on her role as William's mother. A work written by a mother deprived of her two sons as a result of the actions of their father will inevitably be read by many readers as the work of a pathetic Griselda . 
This assessment of Dhuoda's Manual is inevitable but unfortunate because the Manual provides some of the most positive metaphors available in literature for all women but especially for women who are mothers. Dhuoda can be read as an active, even militant, mother defining a role for herself that includes responsibilities equal to those of the father in scope and importance. Dhuoda sees herself as an actor in the political and economic affairs of the family as a mother and wife. As a writer, she is skillful and inventive. Pierre Riché, one of Dhuoda's most positive interpreters, reads her situation in Uzés as "Réduit à l'inaction;"'2 the implication is that she had both physically and intellectually participated in the family agenda until she settled, for whatever reason, in Uzés. But, according to Riché, even in her isolation from the rest of her family, "elle écrit un livre à la gloire de son mari et da sa famille, livre qui devrait avoir sa place dans une histoire de l'aristocatie du haut Moyen Age."3 In the process, she also points to the need for a critical reading of the material written by the adversaries of her family, who have successfully tarnished the reputation of Bernard of Septimania and his family. Because her text has been marginalized and her defense of Bernard read as pathetic blindness to the reality of her situation, the opinion of Bernard's adversaries has prevailed.

Whether Hildegard or a higher authority chose the patterns and metaphors that come together in her writing to identify, define, and interpret her role as a prophet and the errors that needed correcting in twelfth-century Europe, the agenda is clear. A male prophet will not do. With God's help, Adam created language. In spite of this fact, Adam is as vulnerable to the Devil's rhetoric as Eve. Hildegard explains that even though men should understand language better than women, their actions and decisions do not bear this out.. Arrogant because they invented language and know how it works, men, like Adam, commit a second sin. By failing to recognize diabolic sophistry in their own words as well as the words of others, they, like Jason in Medea, dare to practice injustice because they fail to recognize it or can "cast a decent veil of words" over it (Medea, 580). 
After centuries of being vilified because the prevailing interpretation of the fall places the blame squarely on Eve's fragile shoulders, Hildegard emerges to redeem Eve by using divinely transmitted rhetoric. It is precisely the ineptness in rhetoric that she inherited from Eve that qualifies Hildegard who "cannot pull the text apart for analysis"4 as a likely candidate for a New Testament prophet . As with Dhuoda, the humility topos is essential to Hildegard's credibility. Through the humility topos, she reinforces her position as one who could truthfully report what God reveals because she lacks the learning and rhetorical skill that would enable her to distort or misrepresent God's meaning. However, although Hildegard may say this about herself, it is the Devil who causes others to say such things about her. As Hildegard herself points out in her Vita, the "ancient deceiver" causes logical people to doubt the validity of her communications from God when she describes people's reaction to her insistence on following the orders she received to move her convent to Rupertsberg: "What's all this -- so many hidden truths revealed to the foolish, unlearned woman, even though there are many brave and wise men around?'5 It is in fact the dearth of truly brave and wise men in eleventh-century Europe that gives Hildegard reason to call it a "womanish time."

It is not surprising that assessments of Hildegard include the notion that she received her messages from God without "understanding a word of them" or that, less than ten years ago, reputable theologians called her a "fruitcake." That Hildegard garnered as much respect as she did among her contemporaries, given her often strident, but eloquent, scriptural exegesis, admonitions, and criticisms, is in itself remarkable. Once invited into the public discourse arena, although conservative and essentially orthodox, Hildegard proved too formidable, not only because of her divinely inspired message but also because she could, with or without the help of the Almighty, face down authority if she believed her position was justified. 
Perpetua, Dhuoda, and Hildegard carefully crafted their texts so that subversive or unorthodox elements were shrouded in rhetoric that made the writer appear obedient and submissive. Therefore, far more remarkable than the fact that these women wrote, is that they were read and taken seriously by many of their male contemporaries. Disappointing, but not surprising, is that, although they were invited into the public discourse arena by their contemporaries, they have since been invited out. Just as their female predecessors were excluded from the language world of these writers, many of the women writers who followed them proceeded without the models and metaphors these earlier women writers might have provided. Perpetua incorporates into her version of a Christian martyr elements of the picture of a female Greek hero drawn by a male playwright. In so doing she develops the tropes and conventions that became the pattern for the writing of female holy women. Yet few, if any, of those holy women knew Perpetua's text or the texts of other women writers who preceded them. The conventions came to them through the writing of the men who wrote Scripture and the church fathers who interpreted it. Hildegard was one of Perpetua's beneficiaries, but the patterns and metaphors that come together to make meaning in her text are from Scripture and doctrine. Nevertheless, Hildegard's visionary writing reveals a reading of Genesis that counters the doctrinal interpretation of Eve, and Hildegard's letters, sermons, and biography demonstrate that a woman can and, at times, must be a forceful player in the public discourse arena. Dhuoda likewise has only the patterns and metaphors of male predecessors to help her make meaning in her Manual. As a parent concerned about her son and as a wife who shares her husband's concern for the political and economic health of the family, she artfully adapts the forms and language created by men to her agenda. The manual-mirror form had been adapted by clerics as a way to provide readily available Christian instruction to secular noblemen. These instructions also reinforced the role of the church in the lives of these noblemen and, thereby, increased the church's power in the secular life of the people. Likewise, Dhuoda 
realized that she needed to play a significant roll in her son's life in order to guide his behavior in the court of Charles the Bald and to protect him from the hazards she knew existed there. She also felt strongly about maintaining William's allegiance to his family and keeping the importance of the family's interest. uppermost in William's mind. Therefore, it is quite possible that, when all these factors merged in Dhuoda's metaphoric field, the manual-mirror form surfaced as the most logical form for her to adapt as a way of communicating to William. The manual also provided Dhuoda with an opportunity to exercise her creative genius as a writer.

But these women, like the women who have followed in their footsteps, perhaps knew their rhetoric better than some scholars are prepared to admit. They knew that, an idea once written and read, challenges the reader to respond to it, even in the process of dismissing it. Like the many women writers who followed them, these women writers started from scratch in terms of having models and metaphors created by women to draw from in making meaning of their experiences and ideas. The education available to Perpetua, Dhuoda, and Hildegard provided them with male-created metaphors and patterns for identifying, defining and interpreting a woman's thoughts and experiences. But it also gave them an understanding of what writing could do in terms of preserving their thoughts and words. They knew that, once their thoughts and experiences were written in a way that would be acceptable to those who controlled access to the public discourse arena, they could be read by readers in other places and other times. Nevertheless, the fact that something in their experience suggested writing as a way to confront a perceived crisis is remarkable. That they, like the characters in the male-authored plays and the narratives available to them, could move into the public discourse arena without being read as the curse of Medea is even more remarkable. That, under these circumstances, they might also try to answer the question "Who painted this woman?" is astounding. The metaphors available to them were created by men, and although the metaphors these women created in 
the process of expressing their ideas and experiences were muted by being read as the work of inferior and unreliable authors, their voices are unmuted available now and must not be muted again. As suggested by Alison and the Corinthian ladies, if the patterns and metaphors created by women are recognized and invited into the discourse arena, it is possible that pictures will contain more balanced images of men as well as women. To be complete, the picture needs Perpetua's Greek hero as well as the gloriously contemptible Blandina. Dhuoda's image of a militant mother and gifted writer should be juxtaposed against Griselda rather that being read as a real-life metaphor for her, and her picture of Bernard should be taken as a life-like portrait rather than evidence of her pathetic acceptance of his indifference. The ingenious interpretation of Adam's and Eve's respective responsibility for the Fall presented in Hildegard's visions and the revision of assumptions about gender this interpretation implies deserve serious consideration. 


\section{ENDNOTES}

1. Dronke, Women Writers, 39.

2. Riche, "Introduction," 39. "Reduced to inaction."

3. Riché, "Introduction," 27. "Dhuoda writes a book to the glory of her husband and her family which must have a place in a history of the aristocracy of the high Middle Ages."

4. Bowie and Davies, Hildegard of Bingen, 128.

5. Bowie and Davies, Hildegard of Bingen, 66. 


\section{REFERENCES}

Angela of Foligno. "Blessed Angela of Foligno" Liber de Vere Fidelium Experientia. ed and trans. Elizabeth Alvilda Petroff. Medieval Women's Visionary Literature. New York: Oxford University Press, 1986. pp. 254-63.

Aristotle. Poetics. trans. S. H. Butcher. Critical Theory Since Plato. ed. Hazard Adams. New York: Harcourt Brace Jovanovich, Inc, 1971. pp.48-66.

Aristotle. Politics. trans. Ernest Barker. Oxford: Clarendon Press, 1954

Auerbach, Erich. Literary Language \& Its Public in Late Lantin Antiquity and in the Middle Ages. trans. Ralph Manheim. New York: Pantheon, 1965.

Augustine, Sermons: 280; 281; 282: "Saints Perpetua and Felicitas.'The Passion of SS. Perpetua and Felicity Together with the Sermons of S. Augustine Upon These Saints. trans. W.H. Shewring London: Whitefriars Press, LTD, 1931. pp. 4551.

Augustine. City of God. trans. Gerald G. Walsh, S.J. et al. New York: Doubleday, 1958.

Augustine. Enchiridion. trans. and ed. Albert C. Outler. Philadelphia: Westminster Press, 1955.

Babuts, Nicolae. The Dynamics of the Metaphoric Field: A Cognitive View of Literature. Newark: University of Delaware Press, 1992.

Bakhtin, Mikhail Mikailovich. "From the Prehistory of Novelistic Discourse." The Dialogic Imagination. ed. Michael Holquist. trans. Caryl Emerson and Michael Holquist. Austin: University of Texas Press, 1981.

Bernard of Clairvaux. "Letter to the Abbess Hildegarde." "Letter CCCLXVT" (A.D. 1146). Life and Works of Saint Bernard, Abbot of Clairvaux. Vol. II. ed. Johm Mabillon. trans. and ed. Samuel J. Eales. London: Burns and Oates Ltd., 1889. pp.915-16.

Bower, James. A History of Western Education. Vol 2. New York: St. Martin's Press, 1975.

Bowie, Fiona and Oliver Davies., eds. Hildegard of Bingen: Mystical Writings. trans. Robert Carver. New York: Crossroad Publishing Co, 1990.

Carolingian Chronicles. trans. Bernhard Walter Scholz and Barbara Rogers. Ann Arbor: University of Michigan Press, 1970. 
Clark, Donald Lemen. Rhetoric In Greco-Roman Education. New York: Columbia University Press, 1957.

Clark, Elizabeth A. Women In The Early Church. Wilmington: Michael Glazier Inc, 1983 de Cantimpre', Thomas. "The Life of Christina of St Trond, Called Christina Mirabilis." trans. Margot King. Medieval Women's Visionary Literature.ed. Elizabeth Alvilda Petroff. New York: Oxford University Press, 1986. pp. 184-89.

de Ste Croix, G.E. M. "Why Were The Early Christians Persecuted." Past and Present. 26 November 1963. pp.6-38.

Dhuoda. Liber Manualis. Translated into French with an Introduction and Notes by Pierre Riché. Paris: Sources Chrétiennes 225, Les Éditions Du Cerf, 1975.

Diehl, Ernest Inscriptiones Latinae Christianae Veterae 3 vol. Berlin: Weidmann, 1961.

Dodds, E. R. Pagan and Christian In An Age Of Anxiety: Some Aspects Of Religious Experience From Marcus Aurelius to Constantine. Cambridge: Cambridge University Press, 1968.

Dronke, Peter. Women Writers of the Middle Ages: A Critical Study of Texts from Perpetua (203) to Marguerite Porete (1310). Cambridge: Cambridge University Press, 1984.

Duby, Georges and Michelle Perrot. "Writing the History of Women." A History Of Women In The West: From Ancient Goddesses to Christian Saints. ed. Pauline Schmitt Pantel. trans. Arthur Goldhammer. Cambridge: Harvard University Press, 1992.

Duckette, Eleanor Shipley. Carolingian Portraits. Ann Arbor: University of Michigan Press, 1962.

Euripides. Iphigeneia at Aulis. trans. and commentary Kenneth Cavander. Englewood: Prentice-Hall Inc, 1973.

Euripides. The Children of Herakles. trans. Henry Taylor and Robert A. Brooks. New York: Oxford University Press, 1981.

Flanagan, Sabina. Hildegard of Bingen: A Visionary Life. New York: Routledge, 1990.

Fox, Matthew, O.P.. "Forword." Scivias by Hildegard of Bingen. trans. Bruce Hozeski. Santa Fe: Bear and Co., 1986.

Frend, W.H.C. Martyrdom and Persecution in the Early Church: A Study of a Conflict from the Maccabees to Donatus. Oxford: Alden Press, 1965.

Frye, Northrop "The Stage Is All the World." Myth and Metaphor: Selected Essays. 1974-1988, ed. Robert D. Denham. Charlottesville: University Press of Virginia, 1990. 
Ganshof, F. L. The Carolingians and the Frankish Monarchy: Studies in Carolingian History. Ithaca: Cornell University Press, 1971.

Godman, Peter. Poetry of the Carolingian Renaissance. Norman: University of Oklahoma Press, 1985.

Greer, Rowan A. Broken Lights and Mended Lives: Theology and Common Life in the Early Church. Pennsylvania: Pennsylvania University Press, 1986.

Hallett, Judith P. Fathers and Daughters In Roman Society: Women and the Elite Family. Princeton: Princeton University Press, 1984.

Harris, William V. Ancient Literacy. Cambridge: Harvard University Press. 1989.

Heffernan, Thomas J. Sacred Biography: Saints and Their Biographers in the Middle Ages. New York: Oxford University Press, 1992.

Hildegard of Bingen. Scivias. trans. Mother Columba Hart and Jane Bishop. intro. Barbara J. Newman. preface Caroline Walker Bynam. New York: Paulist Press, 1990.

Johnson, Mark. Philosophic Perspectives on Metaphor. Minneapolis: University of Minnesota Press, 1981.

Keresztes, Paul. Imperial Rome And The Christians: from the Severi to Constantine the Great Vol 2. Lanham: University Press of America, 1989.

Kraft, Kent. "The German Visionary: Hildegard of Bingen." Medieval Women Writers, ed. Katharina M. Wilson. Athens: University of Georgia Press, 1984. pp. 109130.

Kramer, Cheris, Barrie Thorne,and Nancy Henley. "Perspectives on Language and Communication." Signs: Journal of Women in Culture and Society. vol 3 no. 3. Chicago: University of Chicago Press, 1978. pp. 638-51.

Kramer, Lloyd S. "Literature, Criticism, and Historical Imagination: The Literary Challenge of Hayden White and Dominick LaCapra. The New Cultural History. ed. Lynn Hunt Berkeley: University of California Press, 1989. pp. 97-128.

Labarge, Margaret Wade. A Small Sound of the Trumpet: Women in Medieval Life. Boston: Beacon Press, 1986.

LaCapra, Dominick. Rethinking Intellectual History: Texts, Contexts, Language. Ithaca: Cornell University Press, 1983.

Laistner, M.L.W. Thought and Letters in Western Europe: A.D. 500-900. Ithaca: Cornell University Press, 1966.

Lane Fox, Robin . Pagans and Christians. New York: Alfred A. Knopf Inc, 1989. 
Laurie, S.S. A.M., LL.D. Historical Survey Of Pre-Christian Education. New York: Longmans, Green and Co, 1900.

Lefowitz, Mary R. and Maureen B. Fant. Women's Life in Greece and Rome. Baltimore: Johns Hopkins Press, 1982.

Lefowitz, Mary R. Women In Greek Myth. Baltimore: John Hopkins University Press, 1986.

Lerner, Gerda. The Creation of Feminist Consciousness: From the Middle Ages to Eighteen-seventy. New York: Oxford University Press, 1993.

Lewis, Naphtali and Meyer Reinold ed. Roman Civilization Sourcebook II: The Empire. New York: Harper and Row Publishers Inc, 1966.

Loraux, Nicole. Tragic Ways of Killing a Woman. trans. Anthony Forser. Cambridge: Harvard University Press, 1987.

Marchand, James. "The Frankish Mother," Medieval Women Writers. ed. Katharina M. Wilson. Athens: University of Georgia Press, 1984. pp. 1-29.

Marrou, H. I. A History Of Education In Antiquity. trans. George Lamb. New York: Sheed and Ward Inc., 1956.

Marucchi, Orazio. Christian Epigraphy_Chicago: Ares Press, 1974.

McKitterick, Rosamond. The Frankish Kingdoms Under the Carolingians: 751-987. New York: Longman Inc., 1983.

Moi, Toril. Sexual/Textual Politics. New York: Routledge, 1988.

Musurillo, Herbert, trans. “The Martyrs Of Lyons. The Acts of the Christian Martyrs. Oxford: Clarendon Press, 1972. pp. 62-85.

Newman, Barbara. Sister of Wisdom: St. Hildegard's Theology of the Feminine. Berkeley: University of California Press, 1987.

Nolan, Edward Peter. Now Through A Glass Darkly: Specular Images of Being and Knowing from Virgil to Chaucer. Ann Arbor: The University of Michigan Press, 1990.

Pomeroy, Sarah B. "Women in Roman Egypt."Reflections of Women in Antiquity ed. Helene P. Foley. New York: Gordon and Breach Science Publishers, 1981. pp.303-322.

Pomeroy, Sarah, B. Goddesses, Whores, Wives, and Slaves: Women in Classical Antiquity. New York: Schocken Books, 1975.

Radbertus, Paschasius. Life of Wala. Charlemagne's Cousins: Contemporary Lives of Adalard and Wala. ed. and trans. Allen Cabaniss. New York: Syracuse University Press, pp. 83-204. 
Riché, Pierre. Daily Life in the World of Charlemagne. trans. Jo Ann McNamara. Liverpool: Liverpool University Press, 1978.

Riché, Pierre. Education and Culture in the Barbarian West from the Sixth Through the Eighth Century. trans. John J. Contreni. Columbia: University of South Carolina Press, 1978.

Robeck, Cecil M.Jr. Prophecy In Carthage: Perpetua. Tertullian, and Cyprian. Cleveland: Pilgrim Press, 1992.

Rufus, Musonius. "The Study of Philosophy."(3,4,13a G) Women's Life in Greece and Rome: A source book in translation, selected, ed. and trans. Mary R. Lefkowitz and Maureen B. Fant, 2nd ed. Baltimore: Johns Hopkins Press, 1992.

Saint Ignatius of Antioch. "Letter to the Romans.'The Faith of the Early Fathers: A source-book of theological and historical passages from the Christian writings of the Pre-Nicene and Nicene eras. selected and trans. W. A. Jurgens. Collegeville: The Litergical Press, 1970 pp.21-22.

Son of Charlemagne: A Contemporary Life of Louis the Pious. trans. Allen Cabaniss. New York: Syracuse University Press, 1965.

Sophocles. Ajax. trans. F. Storr. Cambridge: Harvard University Press, 1961.

Stewart, Zeph. "Greek Crowns And Christian Martyrs." Memorial Andre-Jean Festugiere: Antiquite Paienne Et Chretienne. Geneve: Patrick Cramer Publisher, 1984. pp.119-124.

Tertullian. "Baptism." The Faith of the Early Fathers: A source-book of theological and Historical passages from the Christian writings of the Pre-Nicene and Nicene eras. selected and trans. W.A. Jurgens. Collegeville: The Liturgical Press, 1970. pp. 126-29.

Tertullian. "The Soul" The Faith of the Early Fathers: A source-book of theological and historical passages from the Christian writings of the Pre-Nicene and Nicene eras. selected and trans. W.A. Jergens. Collegeville: The Liturgical Press, 1970. pp.143-44.

The Passion of SS. Perpetua and Felicity Together with the Sermons of S. Augustine Upon These Saints. ed. and trans. W. H. Shewring. London: Whitefriars Press, 1931.

Thiébaux, Marcelle. The Writings of Medieval Women. New York: Garland Publishing Inc., 1987.

Thucydides. History of the Peloponnesian War. trans. Rex Warner. London: Penquin Books Inc, 1972.

Turbayne, Colin Murray. The Myth of Metaphor. New Haven: Yale University Press, 1962. 
Van Beek, Cornelius Ioannes Maria Joseph, ed. Passio Sanctarum Perpetuae et Felicitatis. Nijmegen: Dekker \& Van De Vegt, S.A., 1936.

Wallace-Hadrill, J. M. The Frankish Church. Oxford: Clarendon Press, 1983.

Wemple, Suzanne Fonay. Women in Frankish Society: Marriage and the Cloister 500900. Philadelphia: University of Pennsylvania Press, 1981.

White, Hayden. "The Historical Text as Literary Artifact." Tropics of Discourse: Essays in Cultural Criticism. Baltimore: Johns Hopkins University Press, 1978.

Wilkins, John. "The State and The Individual: Euripides" Plays of Voluntary SelfSacrifice." Euripides. Women and Sexuality. ed. Anton Powell. New York: Routledge Inc. 1990. pp. 177-194.

Wilson-Kastner, Patricia et al. A Lost Tradition: Women Writers of The Early Church. Washington D.C.: United Press of America, 1981.

Zuckerman, Arthur J. A Jewish Princedom in Feudal France: 768-900. New York: Columbis University Press, 1972.

Zum Brunn, Emilie and Georgette Epiney-Burgard "Hildegard of Bingen." Women Mystics in Medieval Europe. New York: Paragon House, 1989. pp.3-36. 